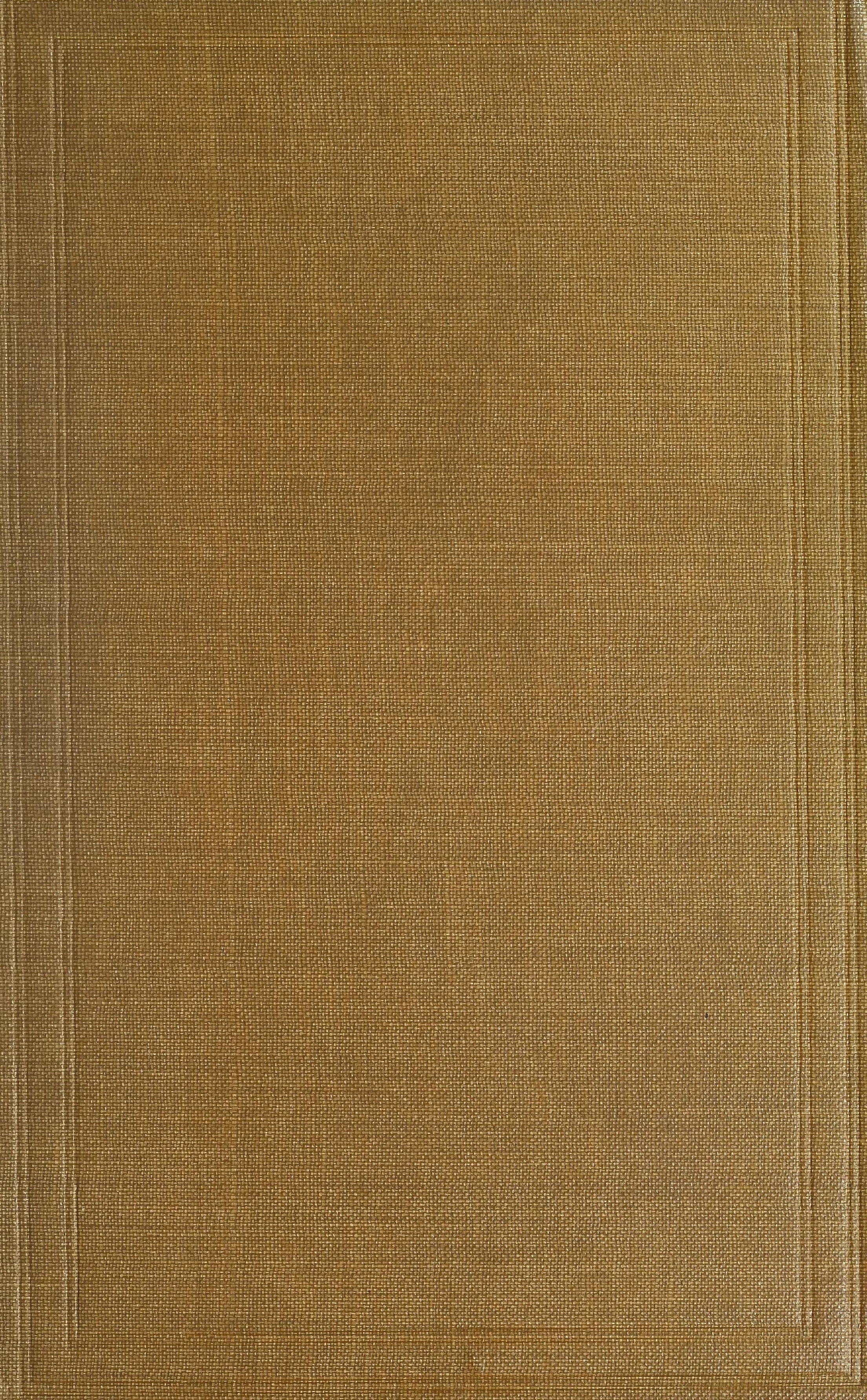





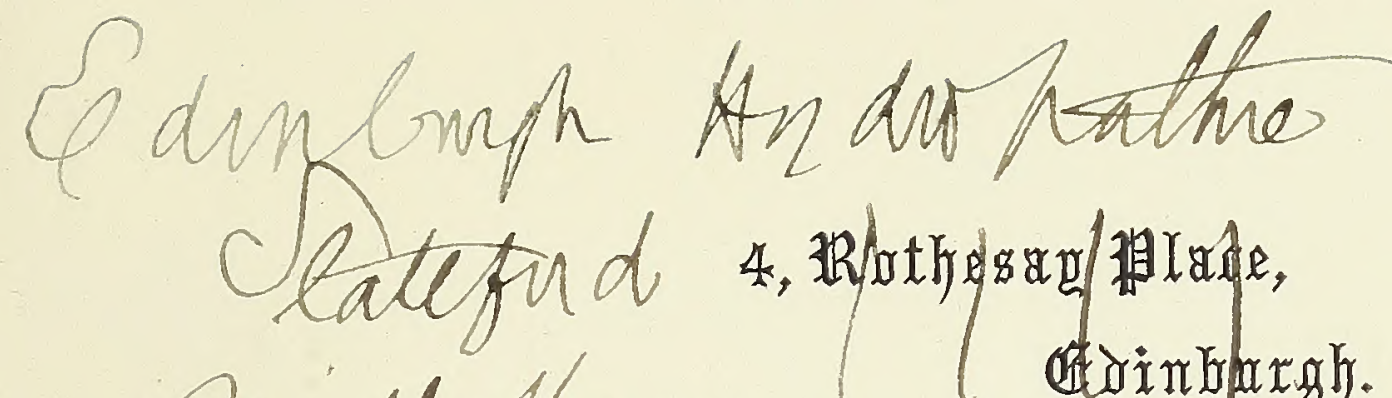

Judethean

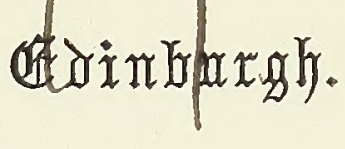

20h Celotar 1910

Dem IN Trootinat,

$\int$ am yarng ath

gom leva of ish malaut $\alpha$

I am ang is the rmeform.

I have conden of truma sommery hm that u ory y Machltirs Life is due to the museun ano culoug hm A 2 an a wh wheh d w w w denbo 
at me

form proty

honacfiliving

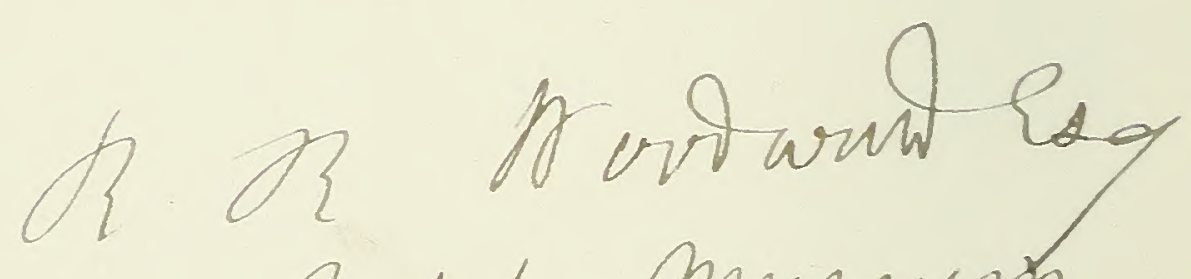

Bulut Mnsewsh

(Nammal Holom)

1 wmwell Dow 
TELEGRAPHIC ADDRESS, "GUIDEBOOK", LONDON.

TELEPHONE 738 MAYFAIR.
50, ALBEMARLE STREET,

W.

oct.21st 1910.

Dear Sir,

Mr.Macki11ivray has sent me Jour letter of the

18th. I wish you had written to me to remind me of our oversight, as it would have saved the trouble of a round-about correspondonce; for it was an overaight on our part, and In ow send you a copy of the book for the British Museurn.

With renewed thanks for the assistance which you

gave us,

\section{Believe me,}

Yours very truly,

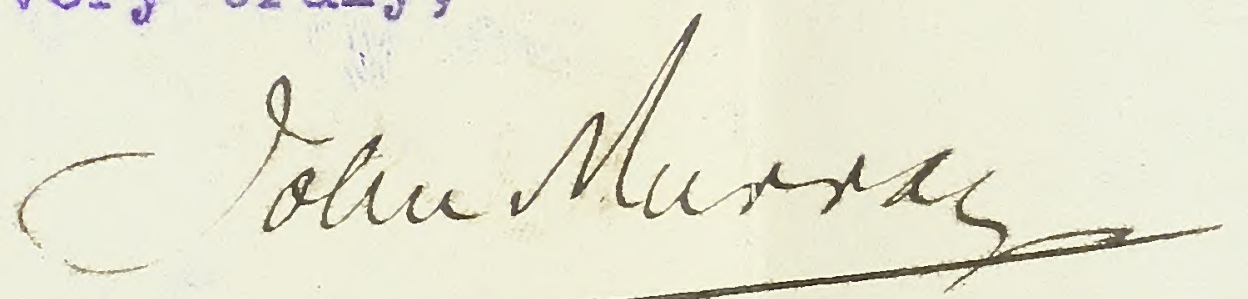

R.G. Woodward Esq., 

LIFE OF WILLIAM MACGILLIVRAY 
96.A.

JI. 


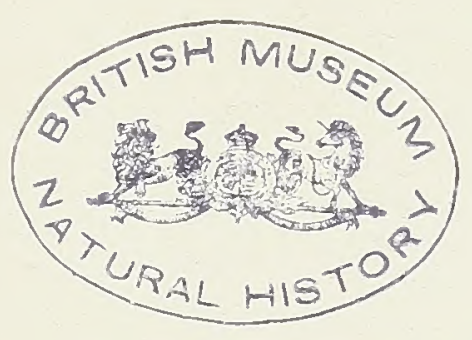




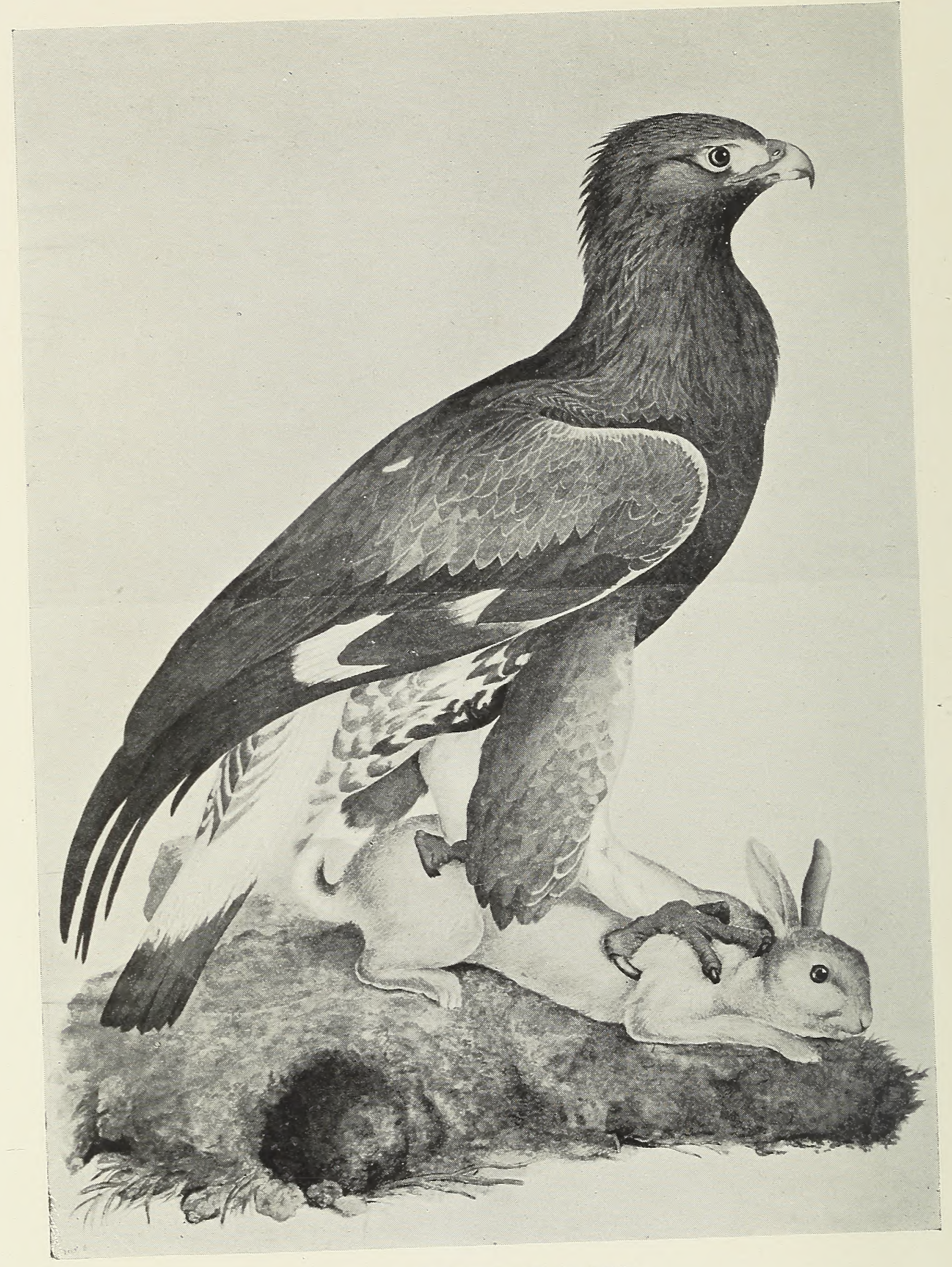

THE GOLDEN EAGLE.

(From a Drawing by MacGillivray in the British Museum.) 


\section{LIFE OF \\ WILLIAM MACGILLIVRAY}

M.A., LL.D., F.R.S.E. ; ORNITHOLOGIST ; PROFESSOR OF NATURAL HISTORY, MARISCHAL COLLEGE AND UNIVERSITY, ABERDEEN

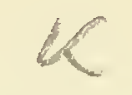

BY WILLIAM MACGILLIVRAY, W.S. AUTHOR OF "ROB LINDSAY AND HIS SCHOOL," ETC.

WITH A SCIENTIFIC APPRECIATION

\section{BY J. ARTHUR THOMSON}

REGIUS PROFESSOR OF NATURAL HISTORY, ABERDEEN UNIVERSITY

WITH ILLUSTRATIONS

"In the eye of Nature he has lived"

\section{LONDON}

JOHN MURRAY, ALBEMARLE STREET, W. 



\section{PREFACE}

THE purpose of this little book is to aid in preserving to some extent a record of the life and work of the most eminent British ornithologist of his day.

William MacGillivray was a native of Aberdeen, lived during his boyhood with his relations in the island of Harris, went to his native city for his university education-spending his long holidays during the period of that education in Harris. While in the course of his goings and comings between Aberdeen and Harris, and of other excursions on foot in many parts of the country, including a walk from Aberdeen to London, his eyes were always open to every object in Nature, both animate and inanimate. All that he saw he treasured in a retentive memory, besides committing much to carefully written journals.

He married in 1820, and the twenty-one years of his life that immediately followed were spent in Edinburgh. During that period, besides attending faithfully to his official duties as Conservator of the Museum of the Edinburgh College of Surgeons, for the last half of that period, he devoted much of his time to the acquisition of extended 
knowledge of Nature, especially of ornithology, which had become his favourite study.

Besides much other scientific literary work, he published during that period the first three volumes of his History of British Birds; and he revolutionised the science of ornithology, by insisting on the necessity for taking into account, in the classification of birds, the internal as well as the external organs, to which latter all ornithologists had, up to that time, restricted their attention for purposes of classification.

In 1841 he obtained the position of Professor of Natural History in Marischal College, Aberdeen, which he held until his death in 1852. During that period he devoted himself with untiring energy and zeal to the discharge of his professorial duties. $\mathrm{He}$ was a most attractive teacher, and many students were drawn to his lectures, although the subjects of them were quite unconnected with their own special courses of study-brother professors even being unable to resist their attraction, while one of them enrolled himself as a student in his class.

In his excursions with his students he taught them how to look at Nature in every aspect and detail of it, while he inspired them with much of his own spirit as a devoted lover of every natural object on which they looked, however small or apparently insignificant.

What a blank he left behind him when he died! How great the loss was to all who had 
relations with him of any kind-a man so loving and so beloved! His loss to science too-quietly progressive and evolutionary as he was in his views - even before the days of Darwin, who can estimate?

The putting together of the pages that follow has been truly a work of love to me, although not without a feeling of deep regret that something much more worthy of the subject had not been undertaken by one or other of his devoted Aberdeen friends, who had seen so much of him during the last eleven years of his life-several of whom could have done it much better than I have been able to do. All or almost all of these friends have since his death followed him into the eternal silence, and he who now holds this pen has reached an age which brings the time near when he also will have joined that company.

I feel it a pleasant duty to express my grateful thanks to those friends who have encouraged and assisted me in putting together this short memorial tribute to my distinguished namesake; and the first of them all to whom I am most indebted is Professor J. Arthur Thomson, who now holds, with so much distinction, the position in Aberdeen University which MacGillivray occupied in his day. His contribution of Chapter VI. of this book"MacGillivray's Scientific Work-an Appreciation" -is a complete and admirable summary of all that MacGillivray was and accomplished as a scientist: and it was on reading it when he sent it to me, 
that I realised for the first time how great a scientist MacGillivray was.

To the officials of the Natural History Department of the British Museum-especially to Mr W. P. Pyecraft-I gratefully acknowledge my indebtedness for the permission they gave, and the aid they so kindly contributed in enabling me to obtain reproductions of the eight of MacGillivray's drawings of birds in the museum, which have been used as not the least attractive of the illustrations in this book.

To the kindness of Mr J. A. Harvie Brown of Dunipace, I am indebted for the facsimile of the letter from MacGillivray to Audubon which forms one of the illustrations. It is an excellent example, slightly reduced, of the writer's very neat and careful caligraphy, which never varies whatever the circumstances in which it may have been written.

To Mr John Murray, the publisher of my small book, it is a special pleasure to me to offer my warm acknowledgments for all his kind advice and guidance in connection with its publication.

W. M.

May 1910. 


\section{CONTENTS}

INTRODUCTORY PAGE

CHAPTER I

His BoyHood in HaRris

CHAPTER II

Aberdeen University Life - Study of Medicine Fascinations of Natural Science

CHAPTER III

The Edinburgh Period from 1820 to 1831 . • • 60

CHAPTER IV

Conservator of the Museum of the Edinburgh College OF SURGEONS FROM 1831 TO 1841- "History OF British Birds"-Audubon's "Birds of Americh," ETC. .

\section{CHAPTER V}

Professor of Natural History in Marischal College AND UNIVERSTTY, ABERDEEN, 1841 To 1852-"History of British Birds" Completed-"Natural History of Diemide and Braemar"-His Death . $\quad 97$ 


\section{CHAPTER VI}

MacGillitvray's Scientific Work: An Apprectation-

PAGE

Introductory • • • • • • • 114

The All-Round Naturalist • • • • • 117

The Open-Air Naturalist • • • • 119

The Observer of Habits . • • . • . 123

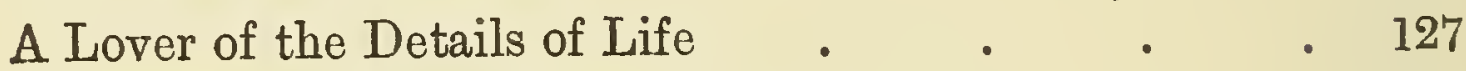

"The Accurate MacGillivray" . . . . 129

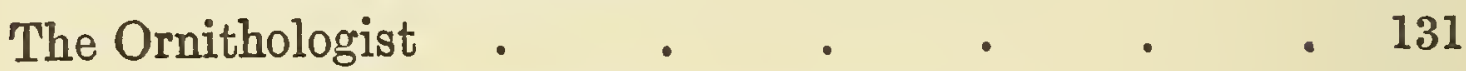

Independence and Carefulness of his Work . 137

His Enthusiasm for Natural History • • 139

His Style • • • • • • • 141

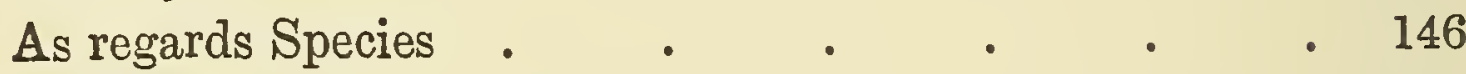

A Teacher . . . . . . . . . 150

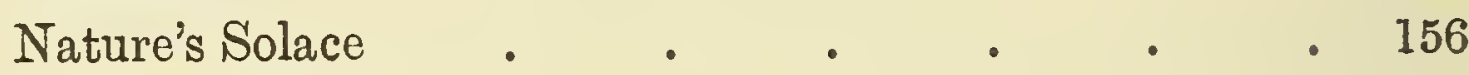

\section{CHAPTER VII}

Extracts from Professor MacGillivray's Works, Descriptive of Bird Life, of Personal Adventure for Scientific Investigation, of Picturesque SCENES, ETC.-

1. The Merlin

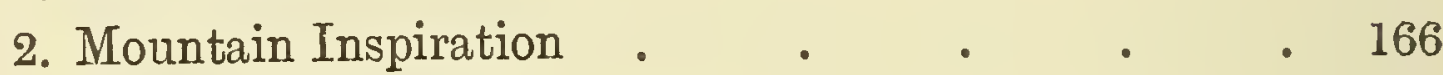

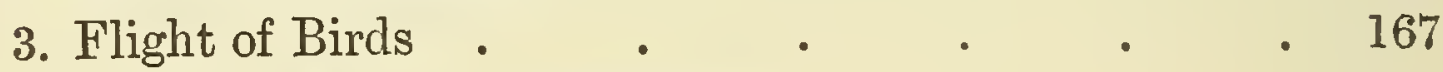

4. A Lover of Nature-Audubon . . . . 168

5. A Tame Young Rock Dove . $\quad$. $\quad$. 169

6. A Winter Bird Scene at the Mouth of the Almond . 170

7. On Clisheim in a Snow-Storm . . . . 172

8. Crossbills Feeding . . . . . 174

9. The Raven in the Hebrides . . . . 175

10. Scene on an April Day . 176

11. Some of Professor MacGillivray's Friends . . 178

12. The Song of the Blackbird • • • 178

13. The Song of the Thrush . . . . . 180

14. The Carol of the Lark . . . . . 181

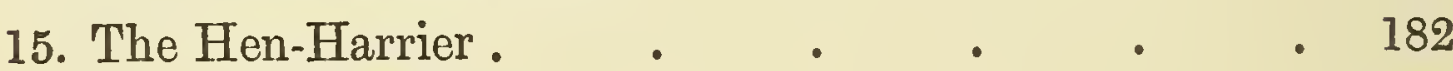

16. The Golden Plover • • • • . 184 


\section{CONTENTS}

Chapter VII. - Extracts from Professor MadGillivray's

Works, ETC.-Continued.

17. The Common Ring-Plover . 186

18. The Sea-Pie . . . . . . $\quad$. 187

19. Dunlins Feeding . • • . . $\quad$ • 188

20. The Common Snipe . $\quad$ • . $\quad$ • 191

21. The Grey Heron . • . . . . 194

22. The Great Black-backed Gull • • • . 194

23. Promise of a Bright Day . • . . 195

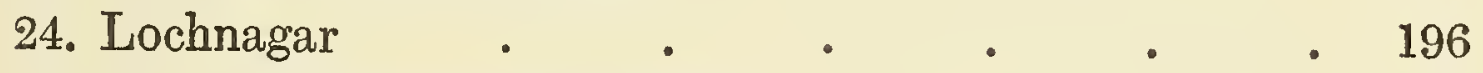

25. View from Invercauld Bridge . • . . 197

26. Object of the Study of Nature . • • . 198

27. The Scenery of Benabuird . • • . 199

28. Aged Birch Trees • • • . . 200

29. The Wind in the Beallach-bhui Forest . • • 202

30. Merry-making of Birds . • . . . 203

31. The Highland Moor . . . . . 205

32. Three Pine Trees. • • • . . 208

33. Home • • • • • . . 209

34. Scene at Torquay . . . . . 211

35. "Conclusion" . . . . . . . 212

INDEX • . . . . . . . 215 



\section{ILLUSTRATIONS}

The Golden Eagle . . . . . Frontispiece

King's College, Aberdeen, where MacGillivray

SrudiEd. From a photograph kindly lent by

Mr G. P. Duffus . . . . $\quad$ To face page 6

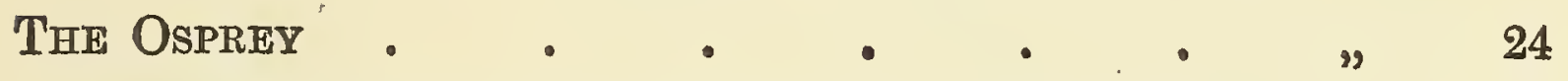

The Peregrine Falcon, Adult Male and Female $" 44$

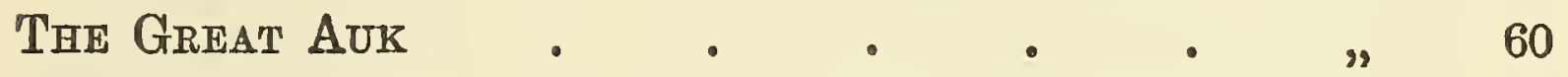

Reduced Facsimile of MacGillivray's Hand. WRITING. From a letter kindly lent by $\mathrm{Mr}$ Ruthven Deane, Chicago, through Mr J. A. Harvie-Brown, Dunipace • • • • " 68

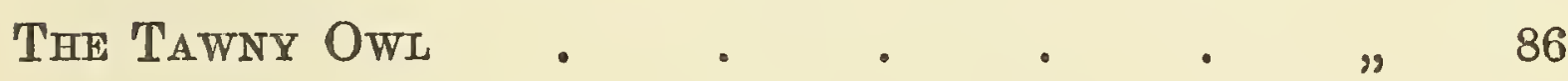

Old Gateway into Quadrangle of Marischal College, Aberdeen, where MacGillivray TAUGHT. From a photograph kindly lent by Mr G. P. Duffus • • • • • $\quad$ • 98

Winter Scene in the Chanonry, Otd Aberdeen, where MacGilitivay Lived for a Time. From a photograph kindly lent by $\mathrm{Mr}$ W. F. Webster . . . . . . " 108

Nestling Cuckoo being Fed by a Meadow Pipit " 126

The Rock Dove, Adult Female and Young . " 168

The RAVen $\quad$ • 



\section{LIFE OF \\ WILLIAM MACGILLIVRAY}

\section{INTRODUCTORY}

William MacGillivray was born in Old Abeldeen in 1796, the son of a surgeon in the army. When three years of age, he was taken to the island of Harris, where at the farm of Northtown, occupied by two uncles, brothers of his father, he had his home while his father was absent with his regiment (the Cameron Highlanders). His uncles were extensive breeders of Highland cattle, and his father had arranged to retire from the army with a view to following the same occupation on the island of South Uist; but he was killed in the battle of Corunna on 16th January 1809.

No detailed biography of Professor MacGillivray has ever been written, and the materials for such do not now exist. From an early period he kept careful journals of his life and work, and from these a biography of great interest and value could have 
been compiled; but unfortunately all but two volumes were accidentally destroyed by fire in Australia many years ago. I recently discovered that two volumes in MacGillivray's neat and careful handwriting remained in the possession of the family of the late Dr Paul MacGillivray, an eminent surgeon in Australia, son of the Professor; and having been allowed the privilege of perusing them, I found them to be of great interest and importance, and I shall make use of them freely in the following narrative. One of these volumes, the earlier in date, is titled, Journal of a Year's Residence and Travels in the Hebrides, by William MacGillivray, from 3rd August 1817 to 13th August 1818, vol. i. ; and the second, the later in date, is titled, Notes taken in the Course of a Journey from Aberdeen to London, by Braemar, Fortwilliam, Inveraray, Glasgow, Ayr, Dumfries, Carlisle, Keswick, Kendal, Manchester, Derby, and Northampton, in 1819, by William MacGillivray.

I prepared a short sketch of MacGillivray's life and work a few years ago, for private circulation among relations and friends who were specially interested in the preservation of his memory, most of these having been students in his Natural Science classes in Marischal College, Aberdeen. That sketch was the outcome of a movement then made and successfully carried out for the erection of memorials of him in Edinburgh and Aberdeen-the one in Edinburgh being a monument at his grave in the New Calton Cemetery, and that in Aberdeen 
being a beautiful bronze tablet in the Natural History Museum in Marischal College.

MacGillivray's life history of fifty-six years is conveniently divisible into five successive periods, and I shall so treat it in the narrative which follows. 


\section{CHAPTER I}

\section{HIS BOYHOOD IN HARRIS}

The first period extends from the time of his leaving Aberdeen for Northtown when three years of age, until he returned to it at the age of eleven, for such further education as was not obtainable in the Hebrides. The parish school at Obbe in South Harris is within a boy's walking distance of Northtown, and it was, no doubt, to it that William MacGillivray daily resorted for his earlier education, which was probably little, if at all, inferior to what it was in many other parish schools in Scotland at that time. In addition to the ordinary branches of a parish school English education, it is not improbable that he made some progress in Latin, as he was only one year at school in Aberdeen when, at the age of twelve, he began his university course of study. At that time it was not unusual for young boys to enter the university. Nowadays the average age of entrants to Aberdeen University is about nineteen.

But besides his school education in Harris, he must in these early year's have learned much that favoured the native bent of his mind towards the 
study of Nature. The sea, the rocks, and the mountains in their ever-varying aspects, in summer and in winter, in sunshine and in storm, with their wild fowl in vast numbers - species succeeding species in constant movement in their respective seasons according to their habits and the necessities of their nature-were all fitted to minister to the growth of a mind which was naturally contemplative, and at the same time extremely observant, sympathetic with every form of life, and readily responsive to the grandeur and the beauty of Hebridean scenery.

There is no existing record of how he passed those years, but that "the foundations of his mind" had then been laid, with promise of subsequent growth in the direction of its ultimate development, there can be no doubt. In a poem, found among his papers after his death, he writes:

"The solitudes of Nature were my school, And in the moaning voice of streams and winds, Without the aid of dull scholastic rule,

I felt the tone which in the lone heart finds its echo." 


\section{CHAP'TER II}

ABERDEEN UNIVERSITY LIFE--STUDY OF MEDICINEFASCINATIONS OF NATURAL SCIENCE

The second period extends from the time of his return to Aberdeen, first for further school education, and afterwards for his university course of study at King's College, which he entered when twelve years of age, just one year before the death of his father at Corunna. After finishing his Arts curriculum, and taking his M.A. degree, he entered on the study of Medicine in $\mathbf{1 8 1 4}$ or $\mathbf{1 8 1 5}$ as pupil to George Barclay, M.D., Physician to the Aberdeen Infirmary and Lecturer on Surgery in King's and Marischal Colleges. Dr Barclay was himself a young man-only about three years older than MacGillivray. He was a native of Aberdeenshire, and youngest son of Charles Barclay, Esq. of Templeland, in the parish of Auchterless. He was much respected and trusted as a physician, and beloved by all who had relationships with him whether professionally or as friends.

MacGillivray, during his period of study at Aberdeen, was in the habit of spending his long summer holidays with his relations at Northtown, 


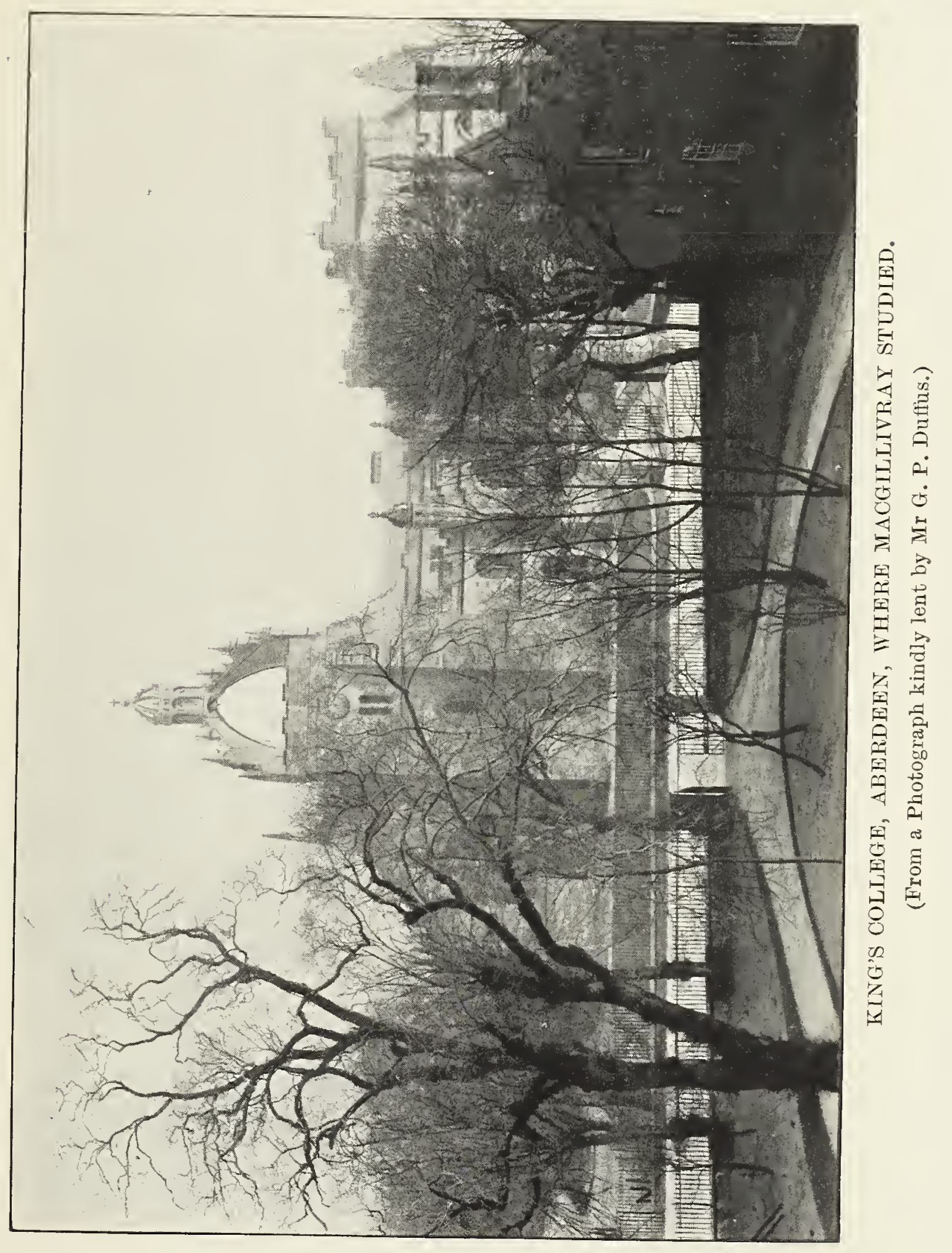

$\stackrel{8}{3}$ 
(2) 
his land journeys to and fro being always made on foot.

While in Harris during these holidays, a good deal of his time was devoted to teaching in the parish school, and a local tradition of him is that he was a most attractive teacher, often directing the minds of his pupils to those aspects of Nature, both animate and inanimate, in which he was himself specially interested, dwelling much on the evidence of creative power and design which he found everywhere in Nature. Much of his holiday time was spent in watching, by night as well as by day, the habits of birds, and he often concealed himself for many hours continuously, now in some cave or rocky recess by the shore, from which the variety of swimming birds could be most readily seen, and again in some temporary shelter erected on the higher cliffs, from which the eagle, the osprey, the raven, and other predatóry birds could be closely observed.

While still continuing to devote himself to medicine with the view of following it as his profession, he began in 1816 the study of botanythe first branch of natural science to which his mind turned with special interest.

In the first of the two MS. journals before referred to, he writes, on 30th April 1818, "Botany, with which I began the study of Nature and which I have cultivated for two years, has been peculiarly fascinating"; and in a passage in his History of British Birds, describing an extraordinary night 
journey which he made from Blair Atholl to the sources of the Dee in September 1816, the year in which he had commenced the study of botany, he says that journey was made on his way back to Aberdeen from a prolonged botanical excursion through the Hebrides and the south of Scotland. This excursion, accomplished no doubt almost entirely on foot, necessarily involved much physical exertion and fatigue, thus showing that he must then have been pursuing his botanical studiesalthough only recently begun-with no little energy and zeal.

On his arrival at Blair Atholl from the south, on the occasion just mentioned, he made inquiry with regard to the route to be followed for the sources of the Dee; and, guided by the information which he received, he proceeded on his way, reaching Blair Lodge in Glen Tilt about six o'clock in the evening. On calling at the Lodge he was kindly received by a woman who provided him with some refreshment, of which, he says, he was much in need. The narrative of that night's adventure as recorded by MacGillivray in his Natural History of British Birds, vol. i., page 175, proceeds as follows :-

"The good woman very benevolently exerted herself to persuade me to remain all night, the hills being, as she said, bleak and dreary, entirely destitute of everything that could afford pleasure to a traveller, and even without human habitation, the nearest house being fifteen miles north. It 
was now six o'clock, and I was certain of being benighted, but I had promised to be at the source of the Dee by noon of next day, and all the dragons of darkness could not have prevented me from at least striving to fulfil my engagement. They had never heard of the spring in question, nor even of the river; no Cairngorm could be seen, and a woman just arrived from the Spey informed me that I should be under the necessity of going through Badenoch before I could get to it. I placed more confidence in my travelling map. All, however, shook their heads when I disclosed my plan, which was to proceed eastward, cross a stream, get to the summit of a ridge of mountains, and so forth, until I should reach the first burn of the Dee, where I expected to find my friend Craigie. It was sunset when I got to the top of the first hill, whence I struck directly east, judging by the place where the sun disappeared behind the rugged and desolate mountains. After traversing a mile of boggy heath, I found myself put out of my course by a long, deep, rocky valley or ravine which I was obliged to double, and before I had accomplished this night fell. I travelled on, however, about two miles farther, and coming upon another but smaller valley, in which I was apprehensive of breaking my neck if I should venture through it, I sat down by a rock, weary, and covered with perspiration. Rest is pleasant, even in such a place as this; and when I had experienced a little of its sweets, I resolved to take up my abode thère for the night. So, thrusting my stick into the peat between me and the ravine below, I extended myself on the ground and presently fell into a reverie, reviewed my life, gave vent to the sorrow of my soul in a thousand reflections on the folly of my conduct, and ended with resolving to amend! Around me were the 
black masses of the granite hills rising to heaven like the giant barriers of an enchanted land; above, the cloudless sky, spangled with stars; beneath, a cold bed of wet turf; within, a human spirit tortured with wild imaginings and the pangs of a sprained foot. 'In such a place, at such a time,' and in such a mood, what are the vanities of the world, the pomp of power, the pride of renown, and even the pleasures of bird-nesting! Having in a short time become keenly sensible that a great portion of vital heat had oozed out of me, I looked out for a warmer situation; but, alas, with little success; for although I pulled some stunted heath and white moss, with which I covered my feet, and laid me down by another crag that afforded more shelter, I could not sleep. After a while, having experienced a fit of shivering, I got up to gather more heath, with which I formed a sort of bed and lay down again. But even heath was not to be obtained in sufficient quantity, so that for a covering I was obliged to bury myself in moss and turf, with the soil adhering. At long, long length, the sky began to brighten in what I supposed to be the north-east, and I was anxiously looking for the approach of morn, when gradually the pale unwelcome moon rose over a distant hill. It was piercing cold, and I perceived that a strolling naturalist, however fervid his temperament, could hardly, if scantily clad, feel comfortable even among moss, in a bog of the Grampians. What a blessing a jug of hot water would have been to such a stomach as mine, aching with emptiness, and nothing, not even tripe-de-roche, to be got to thrust into it. However, morning actually came at last, and I started up to renew my journey. It was now. that I got a view of my lodging, which was an amphitheatre formed of bare craggy hills, covered with fragments of stone and white moss 
and separated by patches of peat bog. Not a house was to be seen, nor a sheep, nor even a tree, nor so much as a blade of green grass. Not a vestige of life can be found here, thought $I$; but I was reproved by a cry that startled me. The scarlet crest and bright eye of a moor-cock were suddenly protruded from a tuft of heather, and I heard with delight the well-known kok, kok of the 'blessed' bird,' as the Highlanders call him. It was a good omen; the night and dulness had fled, and I limped along as cheerily as I could. My half-frozen blood soon regained its proper temperature; ere long I reached the base of the rocky ridge, and after passing some hills, traversing a long valley, and ascending a mountain of considerable height, I took out my map, and looking eastward below me, saw, to my great satisfaction, a rivulet running for several miles directly in the course marked. I was assured that this stream, whether the source or not, ran into the Dee, as it proceeded eastward, and therefore I directed my steps toward it. But here, too, a scene occurred which gave me great pleasure. Some low croaking sounds came from among the stones around me, and presently after a splendid flock of grey ptarmigans, about fifty in number, rose into the air and whirred past me on their way to the opposite eminence. On the brow of the hill I found two large fountains, the sources of the stream below, of each of which I drank a mouthful, and proceeded. My friend, however, was not to be seen; but it was too early; and so to pass the time I explored another of the sources of the rivulet that rose farther up in the glen. But at length the scene became too dreary to be endured: desolate mountains, on whose rugged sides lay patches of snow that the summer's suns had failed to melt: wild glens, scantily covered with coarse grass, 
heath, and lichens; dark brown streams gushing among crags and blocks, unenlivened even by a clump of stunted willows: and I followed the rivulet, judging that it would lead to the river, and the river to the sea. For seven long miles I trudged along, faint enough, as you may suppose, having obtained no refreshment for eighteen hours, excepting two mouthfuls of cold water; so that even the multitudes of grouse that sprung up around me ceased to give much pleasure, although I had never before started so many, even with a dog, in a space of equal extent. At one o'clock, however, I came to a hut, tenanted by a person named MacHardy, who, expressing his concern at my having been out all night, treated me to a glass of whisky and some bread and mill. At this place, Dubrach, stood three half-blasted firs, and about a mile and a half farther down I came upon a wood, the first that I had seen since I left Blair. The silver Dee now rolled pleasantly along the wooded valley, and in the evening I reached Castleton of Braemar, where, while seated in the inn, at a little round table, reading Zimmerman on Solitude, which, to my great joy, I had found there, and sipping my tea, I heard a rap at the door. 'Come in,' said I; it was my best friend, with whom I spent a happy evening, in which, I believe, little mention was made of ptarmigans, grey or brown."

I have thus quoted in full MacGillivray's account of that midnight journey, not only on account of its extremely interesting and splendidly picturesque character, but as a narrative of adventure, strikingly illustrative of some of the strongest and most enduring features of his mental constitution and habits. 
In the preface to his Descriptions of the Rapacious Birds of Great Britain, published in 1836, MacGillivray says he began the study of zoology in 1817, that is, one year after he had commenced the study of botany-and probably in the earlier part of that year-when he was qualifying in Aberdeen for the medical profession. His only guides in his studies then were, he says, Linnæus and Pennant, while he "knew no living wight" who had any knowledge of the subject except a fellow-student, his "best friend," William Craigie, who accompanied him in his excursions in quest of plants and animals, both of them "most zealously striving," he writes, "to add to our common store of knowledge in zoology and botany." "How many pleasant and successful excursions," he continues, "we made together on the romantic banks of the Don, the pebbly shores of the Dee, the rocks of the Cove, the sands of the sea-shore, and the bleak moors of the interior, I cannot tell."

Botany, with which he "began the study of Nature," led to his taking a special interest in zoology, its sister science; and probably he was induced all the more readily to have recourse to it from his previous familiarity with bird life in the Hebrides, and through the sympathetic influence of his "best friend," who appears to have been in advance of him in the knowledge of both botany and zoology.

The zealous co-operation of the two friends in 
prosecuting their study of these sciences, doubtless absorbed much of their time and thought in the first half of the year 1817, to the advantage and enjoyment of both.

The earlier of the two extant MS. journals, above referred to, begins thus :- "Old Aberdeen, Sunday, 3rd August 1817," and proceeds as follows :-

"I am again determined for a tour through part of the Highlands and Isles. In regard to my motives, the principal one is connected with the article pecunia, but it would be doing injustice to my favourite study not to say that natural history also puts in its vote for the expedition. Mr James Shand, actuated by a desire of extending his knowledge on topography and zoology, intends to accompany me. He has already made his departure, but will meet me to-morrow at Kemnay. My baggage will be heavy, but I submit with cheerfulness to any temporary inconvenience when it becomes the means of procuring permanent benefit. I may here with propriety enough give an account in detail of my accoutrements. In the first place, my clothes differ in nothing from those commonly worn. I take some changes of femoralia and pectoralia, linen, stockings, and two pairs of shoes. My hat is just like those of my neighbours, without the vast umbelliform brim which characterises the physical and Linnean cut! For my studies and amusements by the way, I take the first part of the first and third volumes of the Systema Naturce of Sir Charles Smith's compendium Flora Britannica, Campbell's Pleasures of Hope, drawing paper, pencils, paints and crayons, paper, ink, and pens, one pound of gunpowder, six pounds of shot, flints and bullets, powder-horn and fowling piece, hanline and hooks, and a quarter a pound of snuff. 
The other articles which can scarcely be reduced to any distinct class are the following: pocket compass, knife, soap, razors, silk thread, wax, buttons, sharpening stone, needles, lancets, opium, a flute and some small boxes-all, excepting my gun, packed into two bundles, clapped upon my shoulders after the manner of a knapsack. The objects in view are, money to be obtained from some of my friends to enable me to prosecute my studies, my improvement in natural history, particularly in ornithology, ichthyology and mineralogy, botany too, inurement to hardship, the habit of early rising, dexterity in the use of the gun, proficiency in physiognomy, knowledge of men and manners, romantic ideas, poetical imagery, sketches of landscape, drawings in zoology and botany, improvement in taste, some patience, resolution, and inflexibility. If I catch rightly at opportunities I have a fair chance of accomplishing all those ends-objects more particularly in view are an interview with my uncle, the collection of shells and birds and plants. . . . If I had lived in the days of chivalry, I had certainly been another Quixote."

The accomplishment of all these objects as the result of the tour was certainly an undertaking which few young men would have proposed to themselves; and although, taking them all together, they do appear to suggest that he was not a little of a Quixote, yet they give evidence of a mind that would not be satisfied with following out a life too much restricted to any of the professional grooves which were open to his choice.

The journal contains graphic and interesting narratives of incidents which occurred by the way 
-descriptions of all varieties of scenery, detailed lists of plants collected, notices of birds which were seen, and occasionally fine passages of reflective thought.

On one occasion they met a band of tinkers, and as one of them, an ex-soldier, appeared to be rather threatening, they took the precaution of loading their fowling pieces in order to be ready for any emergency.

As MacGillivray was accustomed to long journeys on foot, he did not feel much the fatigue of the journey, although the daily distances accomplished at times were considerable; but it was otherwise with his friend, and the following is an interesting account of how they spent a night near the head of Loch Maree :-

"We saw two people from Pollewe who were driving cattle. They informed us that the Stornoway packet had sailed in the morning, but would be expected on Wednesday. After giving them a dram and taking one ourselves, we set out under the resolution of sleeping in the hills. Accordingly after proceeding about a mile we began to look out for a convenient station, and after some search found one. It was the bed of a torrent situated upon the side of a high valley at the upper end of Loch Maree. We pulled some heather which we put under us, and after eating of some biscuit and beef which we had taken with us, addressed ourselves to sleep. But the rain fell in heavy showers, and Mr Shand grew sick and shivered excessively. So after some time we again fell to pulling heather, with which we made a sort of canopy to protect our heads and shoulders from 
the rain. It felt exceedingly cold. Mr Shand, who had not been accustomed to hardship or privation, felt the effects of this more than I who had enjoyed full opportunities of becoming inured to cold, hunger, and fatigue. Mr Shand continued shivering, while I fell asleep; nor did I wake until daybreak, when my companion informed me that he had spent the time very uncomfortably.... We proceeded along the lake; the rain fell heavily and we were soon wetted to the skin. Our condition was rendered more distressing by Mr Shand being unable to march with sufficient quickness. The road near the northern extremity of the lake passes over a high and very rugged hill on its summit. We arrived at Pollewe in a woeful plight about 4 o'clock."

Then follow picturesque sketches of the scenery of Loch Maree, and this passage with regard to the beneficial effects of travelling:-

"Travelling I conceive to be of the greatest utility, not merely to the naturalist, the poet, and the painter, but also to the moralist. Sure much am I beholden to it. It has disclosed to me faults which neither I, under dissimilar circumstances, could discover nor my friends inform me of. I have reaped most advantage from solitary travelling. ... Solitude is the parent of contemplation, the source of virtue and of science. The bosom is the sanctuary to which we should flee when harassed with care, crossed by disappointment, tortured by remorse. The men who fly from solitude as from a demon are weak as the ghosts of Ossian."

The two friends continued on their journey by 
Stornoway to Harris, where MacGillivray's uncle lived.

MacGillivray's uncle was "tacksman " of Northtown, a farm of considerable extent, with numerous crofter and cottar dependants on it. These contributed the whole of the manual labour which was required for the working of the farm-as was the case with all the other Harris "tacksmen." The uncle, then considerably advanced in age, had recently married Mary $M^{\circ}$ Caskill of North Harris ; and Marion, a sister of hers, was at that time resident with them. Young MacGillivray soon got into a very friendly relationship with Marion, which gradually deepened into an affectionate attachment, and eventually led to marriage.

The social life of Harris at that time appears to have been of a peculiarly interesting character. The greater part of the island was let by the proprietor in large farms to "tacksmen," as the lessees were designated. These "tacksmen" appear to have been a well-educated class, then peculiar to Harris, superior to the ordinary Highland farmer of the period, being "gentlemen" according to the old Statistical Account of Scotland, having had their origin in a kind of family relationship with Macleod, the proprietor to whom they looked up as their chief.

These tacksmen and their families, as appears from MacGillivray's journal, had much pleasant intercourse among themselves, frequent visits being interchanged by the members of the different 
families, visitors always being welcomed, however unexpected. It was not unusual to prolong a visit over several days at a time, to the mutual enjoyment of both visitors and visited. To young MacGillivray this social life was very congenial. He entered fully into it, and derived no little benefit and enjoyment from it. Again and again, however, the conviction came home to him that his time and his mind were being too much diverted from the main purpose of his visitthe prosecution of his natural science pursuits; and again and again he formed and recorded in his journal strict resolutions with a view to amendment, for the carrying out of which, however, the social attractions always proved too strong.

But his time was by no means wasted during the visit, which was prolonged, as appears from the journal, to 1st May 1818. He did much in the course of his walks and excursions throughout Harris and the neighbouring islands to extend his knowledge of botany and zoology, the two branches of science in which he was then most interested. He also did something to geology. He never went out without his gun, and lost no opportunity of obtaining specimens of birds for examination. Nothing of interest in connection with his scientific pursuits escaped his attention, and the daily record of knowledge gained was always carefully entered in his journal. He felt, however, the want of scientific books, Smith's Flora Britannica and De 
Luc's Geology being all that he had brought with him.

During his residence at Northtown on this occasion he appears to have been recognised and trusted as a doctor, and was frequently called on for medical aid and advice which he always willingly gave, although often at considerable inconvenience to himself. He also showed no little aptitude for matters of business, and on one occasion he took in hand and carried through successfully an important business affair in connection with the renewal of his uncle's lease of the farm of Northtown, the uncle himself having failed in bringing it to a conclusion. Indeed he was always ready, in so far as within his power, to afford kindly help to any one in need of it. He was a great favourite with all his relations and friends in Harris, and he acknowledges in his journal that he had gained much in health, both of body and mind, during that prolonged stay in the West.

When preparing to leave Harris for the continuation of the tour he had projected before leaving Aberdeen, he made a careful "survey" of his physical and mental condition, and of the various educational and other acquirements of which he was then possessed. This "survey" he sets forth in some very interesting passages towards the end of his journal. In one of these passages, dated 27th April 1818, after noting various habits which he had resolved to break off, he continues:- 
"I have gained much. I have learned to detest lying and swearing and profanity of every kind, so that a strict adherence to truth and decency of behaviour shall in future be principal parts of my character."

\section{At a later date he writes:-}

"For some days past I have been daily falling off from my former improved state, but I must endeavour to regain what I have lost."

"From reading with considerable attention De Luc's treatise on Geology," he goes on, "I find that I need not be under the apprehension of ever exhausting those parts of the study of Nature which suit my peculiar constitution. New subjects, I am persuaded, will daily present themselves for investigation. The observation of geological indices will henceforth occupy much of my time. On my way to Aberdeen I might acquire considerable mineralogical knowledge if I possessed the necessary books and instruments, but in the deficiency of these I might even do something. I shall at least become acquainted with a few species. I have not yet seen an account of the birds of Britain with which I am entirely satisfied, and I have of late been thinking upon the subject. Perhaps it might not be a bad scheme to attempt the ornithology of Scotland. I certainly would not engage for more. But whether this alone would be acceptable I cannot yet determine. However, I shall begin to note every particular regarding it which $\mathbf{I}$ can observe or collect from credible authority. The time I occupy in this will not be misspent, even at the worst, for I will thus perhaps acquire habits of attention, observation, and activity. I shall probably spend a good deal of time in going through Skye, and I promise myself much pleasure from my wanderings there. I intend also to visit Ross, 
Sutherland, Caithness, and Cromarty, but until my uncle's affairs are reduced to order I cannot determine the plan which I am to follow. In the meantime let me begin my operations by a little drilling, preparatory to my entering on these designs."

Again, under date 30th April, he writes :-

"As I am about to undertake another journey, or rather to begin the completion of my last, I shall note some particular's regarding my present condition, and thus close my journal for the present. To-morrow, being the first day of summer, may very properly be made the first of a new account and of a new mode of arranging matters, more especially as a reform is loudly called for. In regard to the objects which I had in view on this trip, I may say that I have attained them in a greater' or less degree. I have enjoyed for six months past an almost uninterrupted course of good health, more especially for the last three months, during which I have not even experienced a headache of half an hour's duration. Hence I infer that my constitution is mending. Perhaps with due care I may yet attain to such firmness of frame as I might reasonably have expected, had not my own folly and a few adverse circumstances frustrated the intention of Nature. However, I am at present strongly fortified against the assault of every irritating circumstance, and am thus, in so far as regards corporeal constitution, well fitted for any exertion requisite or necessary for keeping in health ; and, as I could not relinquish scientific pursuits, I must endeavour to find some employment which, with a high degree of mental, gives an equal share of corporeal, exertion. This, among other reasons, inclines me to follow the study of Nature.

"Since my arrival hére $I$ have made but few 
acquirements for want of books. The new studies in which I have engaged are mineralogy and geology."

He then proceeds:-

"My acquirements may be enumerated in a few words. Of most of the physical sciences I have got a smattering. In zoology I have made considerable progress, particularly in ornithology. I have just begun the study of mineralogy. But botany, with which I began the study of Nature, and which I have cultivated for two years, has been peculiarly captivating. Yet, though I may be well acquainted with the principles and terms of the art, I have not examined above six hundred species.

"These are the departments of science to which I am most inclined by nature. Consequently these in which I ought to excel.

"Of medicine, including anatomy, physiology, medicine proper, surgery and pharmacy, I know a little, and just a little. Chemistry, as applicable to medicine, engaged my attention. I have heard lectures on it and studied it with some attention.

"The other sciences of which I have just a smattering and nothing more are mathematics, philosophy, natural and moral, and agriculture. Of civil history I know very little.

"Thus I cannot boast of having acquired a thorough knowledge of any science. Yet I must confess I am in a fair way, and if I can but acquire habits of industry and assiduity I may, before the end of four or five years, be eminent in something. I have certainly laid a good foundation, and the knowledge which I possess of so many sciences, little as it is, will enable me with greater ease and certainty to excel in any one of them or any other." 
He had thus taken very fairly "the measure of himself," and was able not only to realise intelligently the extent and advantage of the acquirements of which he was then possessed, but also what further course he ought to follow for the attainment of those scientific purposes to which he had come to feel that his life ought in the main to be devoted.

Although he felt, after a residence of many months in Harris, that the time had arrived for proceeding to carry out the remainder of his projected tour, which was to include a visit to Skye and the northern counties of Scotland, yet we have no information as to how far he was able to carry out that plan. Its practicability, as appears from a passage in his journal just quoted, depended on certain arrangements with regard to his uncle's affairs being completed; but we have no means of knowing where he actually went after leaving Harris, or whether indeed he did leave it at the beginning of May, as he had decided to do. The title prefixed to the journal-no doubt written after the tour had been completed-appears to imply that he had abandoned his plan, so far at least as regards the northern counties, as that title describes the completed tour from 3rd August 1817 to 13th August 1818 as " $A$ Year's Residence and Travels in the Hebrides, vol. i."

I do not doubt that another volume giving an account of where and how he spent the three and a half months, from the beginning of May to 13th 


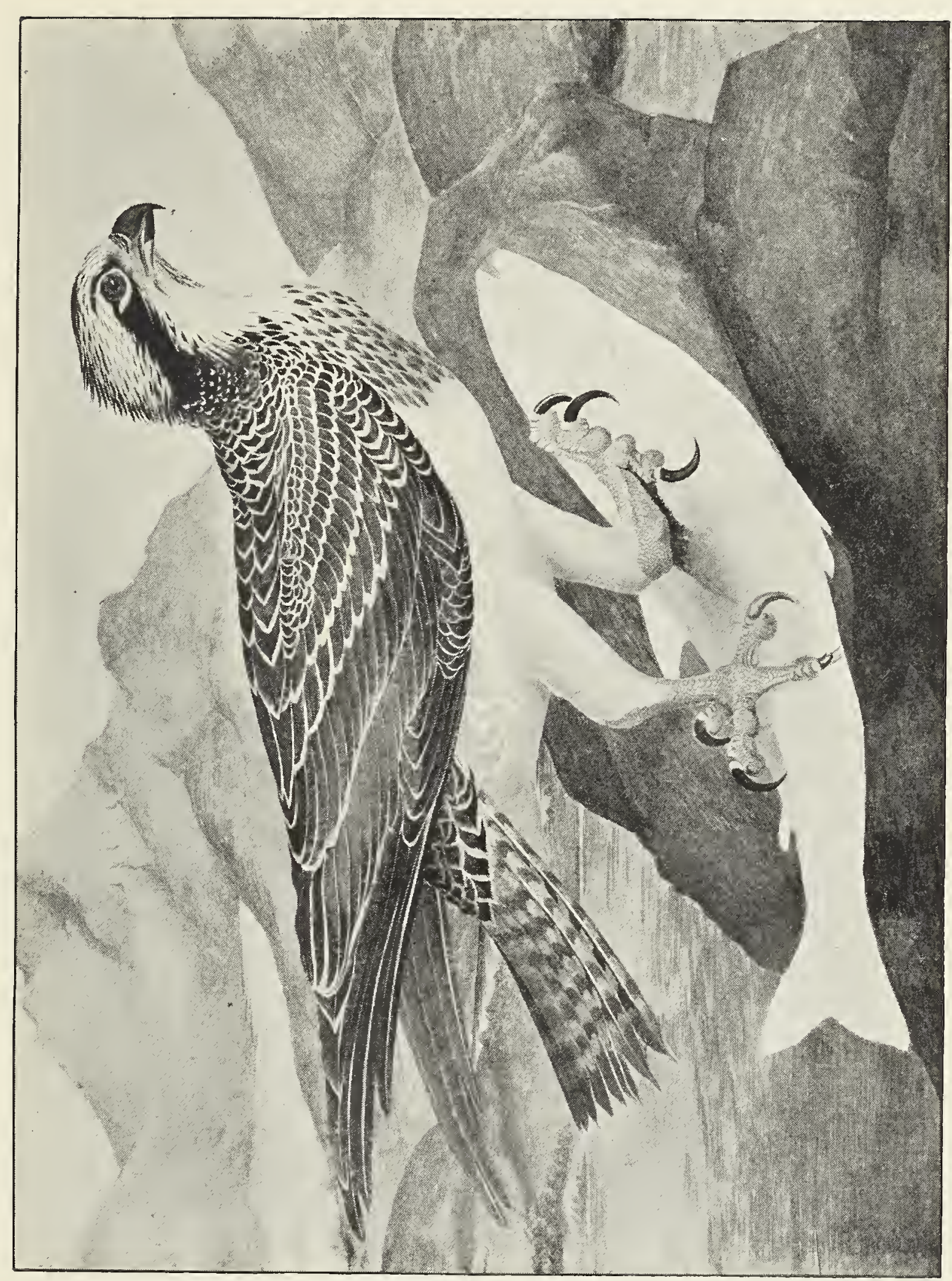

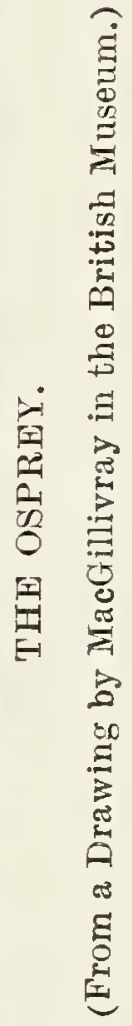




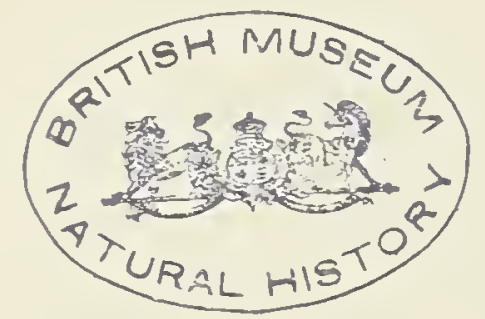


August (the date of his return to Aberdeen) was written; and how interesting the details of that second volume would have been, whether the time was spent in carrying out the original plan, or in a continued "residence and travel" among the Western Islands. How much these details would have revealed had the record of them, made from day to day as in the case of Vol. I., been still in existence. It would have shown how his knowleged of Nature was being constantly enlarged, how natural science was becoming more and more the all-engrossing pursuit with him, and with what untiring energy and zeal, at the cost of much physical discomfort and endurance, he had persistently continued that pursuit.

During the whole of the year which elapsed between his departure from Aberdeen on 3rd August 1817 and his return to it on 13th August 1818, his mind and time must have been almost exclusively occupied with his scientific pursuits in direct contact with Nature-little if any thought being given to medicine; and probably he found, when again settled down to his studies in Aberdeen, that his zeal for the continued prosecution of medicine had considerably abated.

In the preface to the Rapacious Birds already referred to, he says :-

"The fascination of those pursuits (botany and zoology) were such that, after studying medicine for nearly five years, during part of which time 
I officiated as dissector to the Lecturer on Anatomy at Marischal College, I resolved to relinquish it and devote my attention exclusively to natural history."

At what time this resolution was definitely formed and began to be acted on does not appear, but probably it had not been long after the resumption of his other studies on his return to Aberdeen on 13th August 1818. Yet it is not unlikely that from feelings of respect and affection for his friend and teacher, Dr Barclay, he had continued to keep up a warm friendly connection with him as his pupil or otherwise.

I cannot doubt, however, that during the year which followed his return, he had, in co-operation with his friend, William Craigie, devoted himself with so much zeal to the study of botany and zoology, that little time or room for thought was left for the further study of medicine.

In September 1819 he devised an extraordinary plan for a further extension of his knowledge of Nature in its various aspects. This plan was to walk all the way from Aberdeen to London, in order to see the British Museum and other institutions containing objects of special interest to him, and to acquire such further knowledge of Nature as would result from his observations in the course of the journey. So he set out on that expedition, he tells us in his preface to the Rapacious Birds, with his journal and Smith's Flora Britannica on his back. He formed his plan for it at its commence- 
ment, and adhered strictly to it throughout. Day by day he took careful note of all the plants and birds which he saw by the way, recording full descriptions of them in his journal, often late at night and at times in clothes dripping from drenching rain.

In a passage near the beginning of the journal, he writes as follows:-

"Being naturally or perhaps from habit of a restless disposition, I feel inclined ever to bestir me and to be up and doing. In London City there is, I am told, a great collection of beasts and fishes and of birds and other flying things, of reptiles and insects -in short, of all the creatures which have been found upon the face of the earth. Thither therefore I shall direct my steps, because I am desirous of furthering my cognition of these things."

And again he writes that his main object in undertaking the journey on foot was to "extend my knowledge in natural history - especially in ornithology and botany, which can only be done by travelling."

He left Old Aberdeen on 7th September 1819, and in his journal under that date he writes:-

"I rose to-day about half-past four, breakfasted about five, and soon after set out. After passing through King Street, Castle Street, and the Ship Row, I got to Deeside near Black's Brewery. Here I fixed my knapsack on my shoulders. 'The articles contained by it and by my pockets not mentioned are a penknife, a small ink piece with pens, a small itinerary of Scotland, a glass for 
drinking by the way, and a towel. To my dress or clothing I have added a great-coat and a pair of old gloves. Of money I had just ten pounds sterling when I left Aberdeen, nine pounds in small bank notes put into a small pocket in the inner side of my flannel under-vest, one in silver secured in a purse of chamois leather kept in a pocket of my trousers."

The first night after leaving Aberdeen he spent at Charleton of Aboyne after walking a distance of $30 \frac{1}{2}$ miles.

"It is now after nine," he writes in his journal, "and I have eaten a poor supper and taken a glass of whisky and some water."

Then follows a detailed narrative of the day's journey, with a long list of the plants which he had found by the way, and he continues next morning as follows:-

"Last night I bedded at eleven. I had a severe headache and a violent fit of shivering, followed by great heat without sweating. I did not rest very well, and so lay in bed till eight."

After breakfast he resumed his journey by Braemar, the Ben Macdhui mountain range and Strathspey. In his adoption of that route-the most arduous he could have chosen-he was no doubt influenced by that irresistible fascination which the Scottish mountains appear always to have had for him. One night on his way he spent at the base of Ben Macdhui, with an experience similar to that of his midnight journey in search of 
the sources of the Dee in 1816. In his journal he describes that night's experiences as follows :-

"About three or four miles above the Linn, the Dee is joined by a river equal in size, namely the Geaully, the source of which I had explored in 1816, when I came across the mountains from Blair Atholl. Hitherto I had travelled in a westerly direction, but now proceeded northward, following the river. There are no houses beyond the junction mentioned. About a mile above it, I came in sight of a most magnificent rock, with a mountain peak behind it of greater elevation. When I reached this rock, I learned by the light scarlet colour of the clouds on the ridges that the sun was setting. Passing the rock, I entered a valley bounded on both sides by very lofty and rugged mountains, and terminating in a vast mass, towering above the whole. Before I reached the upper end of this magnificent, though wild and desolate valley, night fell. About this time I saw a deer not far from me. Near the upper end of the valley the stream which I had followed separated into two. It was with great difficulty that I clambered to this part to see which was the largest, that I might follow it. Having ascertained that the largest stream came from a valley which branched off at a right angle from the extremity of the main one, I entered this valley and proceeded about three-quarters of a mile. It was by this time completely dark, and I determined to rest myself."

"About midnight I looked up and saw the moon and some stars. They were at times obscured by masses of vapour, which rolled along the summits of the mountains. I had now a better view of my situation. I was near the upper end of a high valley, completely surrounded by enormous 
masses of lock. Behind me, my face being towards the mouth of the valley, there rose at its upper end a high mountain involved in clouds; on the right hand was another, in the form of a pyramidal rock, and, contiguous with it, a peak of less elevation; on the left hand, a high ridge running from the mountain in the north-west, and terminating at the mouth of the valley in a dark conical mass; and, straight before me, in the south-east, at the distance of nearly a mile, another vast mountain. The summits of all were at times enveloped in clouds. The wind, which blew from the west, was not keen, and the night was such as, in comfortable circumstances, might be called warm. Yet on awakening from my slumber I felt chilly, and soon after began to shiver. I then rose, and gathered a few large stones and a good deal of grass and short heath, with which I formed a somewhat snug sort of couch. Unloosing my pack, I took a night-cap and a pair of stockings from it, which I applied to their proper use, for my feet had been wetted in crossing a brook, and my hat alone did not keep my head warm after the perspiration it had undergone. Then, eating a little of my scanty store of barley bread, and drinking two or three cupfuls of water from a neighbouring rill, I lay down, put heather and my knapsack over my feet, placed myself in an easy posture, and fell asleep.

"I awoke fresh, but weak, about sunrise. The stream which I had followed here divided into two, and I chose the largest. It led me to a magnificent corrie, in the form of a deep hollow scooped out of the great ridge, on the left of the glen, as described, but now on my right hand in ascending it. The sides of this corrie were formed of sloping rock of vast height. The rivulet came tumbling down the centre in the form of a cataract. Here the rocks were most abrupt; but I had determined to 
proceed, at least to attempt the ascent. Before I reached the base of the rocks, I felt very weak, and was obliged to halt every now and then. However, I proceeded, and at length, being well accustomed to rock-climbing, found myself on the very summit of this vast mass of rock. It was covered with mist, which rolled rapidly along the ridges. The sun now and then appeared through it. The view through the corrie, which I had just ascended, was delightful-dreadful it might have been to somethe whole glen, the deep corrie just beneath, with its fearful rocks, the opposite mountains with an Alpine lake before me. The scene was truly sublime, and I contemplated it with great delight.

"I had now reached the rounded summit of the ridge, and proceeding along the streamlet, which was the principal object of my research, I traced it to two fountains and several smaller springs. I took a glassful from each of the larger, and drank it to the health of my friends. Near these fountains, which were among coarse granite sand, I saw a covey of ptarmigans, and a small bird, which I took for Alauda pratensis. The only phænogamous plants which grew on the summit of the mountain were Silene acaulis and Salix herbacea, both in abundance, the former still in flower.

"Descending on the northern side of the mountain, I came upon a precipitous corrie, down which I did not venture, and farther on found myself on a precipice, from which I had a view of a deep valley, with a lake and a stream, ending in a plain partially covered with fir. The view from this place was vast, and I thought I distinguished the sea; but of this I was not certain, as the mist obscured the view at times. In my descent I saw a considerable number of ptarmigans, and some specimens of crystallised quartz, though not very 
fine. On the northern side of the mountain some Alpine lakes occurred, in which I could not find anything but Sparganium natans, and a few poor specimens of Caltha palustris, which plant I also saw in the rivulets. Holding still a northerly direction, I crossed a broken plain, and ascended a gentle acclivity, at the end of which I found a larger plain, which I also crossed. At the end of this plain I came to an opening which led into a deep valley, bounded by rocks and rapid gravelly slopes. Descending by this valley, which I found very long and very rugged, into a plain which led to a stream of considerable size, and evidently a tributary of the Spey, I at length reached the low ground, and directed myself westward."

When alone in such a situation as he thus describes, he appears never to have suffered from any feeling of loneliness. His sense of reverential enjoyment was too engrossing and overpowering to admit of such a feeling. "In the mountains he did feel his faith" most intensely - his faith in himself, in Nature, and in God, who was never absent from his thoughts when alone with Nature. Indeed, in his enjoyment of Nature a feeling of the Divine presence was ever predominant.

After spending the night at the base of Ben Macdhui, he proceeded to Strathspey, and spent the next night at Kingussie. "In the dusk," he writes, "I began to feel very melancholy, and to prevent this disagreeable sensation, went out and fell in with an old man with whom I chatted for some time. I then returned, drank some toddy with my landlord, and wrote the greater part of 
this." "This" was the record of his experiences of the previous day and night and of that day's journey, extending to seven large quarto pages, closely and very carefully and neatly written, without a single erasure or alteration.

His next resting place for the night was Aberarder on Loch Laggan, from which he proceeded to Fort William. There he remained two days, devoting one to the ascent of Ben Nevis.

"From the top," he writes, "I had an immense view. In the south, east, north, and north-west, mountains appeared without interruption, only in the east they were lower. In the south they were of a very rugged and desolate aspect - sharp pointed rocks, rugged corries, deep craggy glens, streaks of grey stones and gravel alternating, composed the scene. I looked for the highest mountains, such as Schiehallion and Ben Lawers, but none appeared greatly prominent above its neighbours. There were some tremendous rocks, perhaps the highest which I ever saw, and were at least a thousand feet in height."

Next day he proceeded on his journey southwards, passing through Glencoe, with which he was deeply impressed, his description of which is very striking and picturesque.

Many passages of special interest occur besides those descriptive of the scenery of that part of his route. Here is a reflection with reference to the scenes of one's youth :-

"In the most remote regions of the globe, the mind dwells upon those scenes with delight, and 
almost all who have been obliged to undergo a temporary exile from their native land wish to return to it, and to spend the last years of their sublunar existence in the place where they first drew breath. The remembrance of scenes of this kind were rising in my mind yesterday. I was coming into the vicinity of the Isles. I had friends there whom I loved. The mountains and lakes and heaths and rivers of that land, bleak and barren as it is, are dear to me and ever will be. Was it then blameable in me to wish to spend a few days there? If mankind were utterly destitute of this attachment to localities, many of the great operations dependent on sociality and concurrence of sentiment and operation could not be performed. . . . I feel at this moment a glowing attachment to the land of my forefathers which almost outshines every other."

On approaching Inveraray on his route, he writes :-

"Here I fell in with a woman seated on a chair fixed to a hand barrow, together with a man who appeared to be her husband, and a boy. The woman desired me to carry her to a house at the distance of nearly a quarter of a mile. 'It is too far off,' said I. However, I thought I might do a worse action, and so, with the assistance of the man, carried her to the place mentioned. The usual 'May God in heaven reward you,' was, of course, applied as a recompense, accompanied, however, with an 'as I hope He will,' which very plainly intimated that doubts were entertained regarding the accomplishment of the wish. Poor fool, thought I, if God rewarded every action of this kind, it would be an easy matter to purchase rewards enough." 
He reached Dunbarton by the west side of Lochlomond, and the entry in his journal with regard to it is as follows :-

"After passing a restless night there I rose before eight o'clock and went out to look about me. The Rock of Dunbarton attracted my notice, and I proceeded to it without delay. A soldier accompanied me to its summit. ... The Rock of Dunbarton is, I believe, far superior to those of Edinburgh, Stirling or Dunnottar as a place of defence, because unlike them it rises abruptly from the level plain. It is split into two at the summit, and in the cleft are built barracks. The works are trifling because the place requires very little assistance from art, being an almost complete natural fortress."

As he proceeded towards Glasgow, he says he found that "unlike the huts at Loch Awe and Loch Leven, the abodes of the peasantry are neat and comfortable. Everything, in short, tends to impress the idea of civilisation."

\section{On reaching Glasgow, he writes :-}

"Steamboats appeared in abundance upon the Clyde to-day. The consideration of the effects of civilisation is truly amazing. The room in which I am sitting is lighted with gas, as are the streets and most of the houses of this city. . . . I have been in Glasgow before, and have sailed up the Clyde from the mouth of Lochfyne in Argyll. Yet all that I have seen to-day bore the character of novelty-even the Rock of Dunbarton, and Glasgow itself."

After visiting the Botanical Garden, nothing else of interest remained to detain him in Glasgow, 
so he left for Paisley, through which he passed, and reached Ayr in the evening.

"After searching for nearly half an hour," he writes, "I found a bed. But it had been better for me that I had slept by a hedge, for I am almost covered by tumours and vesications produced by the bites of bugs. I did not sleep through the night, and to-day got up about six, and visited the Brigs o' Ayr. ... How gladly I would have exchanged my bed last night for the couch of grass on the side of Cairngorm."

He was now in the "Land of Burns" with all its associations and inspirations. He visited the scenes which were specially hallowed by memories of the poet, and among them his birth cottage and Kirk Alloway. Of these he writes as follows :-

"I am now in a window of the far-famed Kirk Alloway, but not in the winnoch bunker in the east where sat 'Auld Nick,' for that is placed beyond my reach by a wall across the church to preserve from profanation the dust of a parcel of precious lairds of Doonside. I am now much better than I was three hours ago. I left Ayr about ten and wandered about for some time in search of this place, until at length, about a quarter of an hour ago, I found it. Not far from this is the cottage in which Burns was born. It is now converted into a 'public house,' as it is called. I entered it and got half a mutchkin of the favourite potation of the unfortunate bard. I knelt down upon the floor with my hat off. 'Immortal Burns,' said I aloud, 'here on my knees I do homage to thy genius,' and pouring the liquor upon the floor, added, 'and pour forth this libation to thy 
memory.' Poor fellow! There never was a genius upon earth whose memory is dearer to my heart. ... Big drops are trickling down my cheeks, I know not why. I cannot scrutinise my feelings. The spirit of departed years speaks to my soul, and the meteor phantoms of futurity hover around. My soul is sad. When will the light of Heaven flash through the murky clouds of ignorance and doubt that have enveloped it?"

He then went on his way southward, and he writes :-

"I am now upon the sea-shore ... I am still unwell but not now melancholy. The sight of the glorious ocean has restored my serenity. How I am to be lodged to-night I know not. The nearest town is upwards of 5 miles distant, and I am scarcely able to move. However I shall proceed."

So he proceeded, and reached Girvan, where he remained for the night.

From Girvan he continued his journey by Stranraer, Castle Douglas, and Dumfries. At Dumfries he spent one night; and while there he went out in the evening in search of the grave of Burns. After scaling the wall of the churchyard in which he assumed it would be found, and searching among many monuments, he came upon one more magnificent than any of the others.

"It was in the form of a dome," he says, "supported by eight Ionic pillars. Through the iron railings I could distinguish the figure of a man holding a plough in white marble. This is it, said $I$, and before I had reached the outer gate I burst 
into tears. The monument was enclosed by a stone wall on the top of which was an iron railing, and the gate was locked ... I got over the railing, sat down on the steps, and again burst into tears. My ideas were not precisely defined, and passion does not vent itself in set speeches. The only words which broke forth at intervals between my sobs were 'Poor unfortunate Burns.'... I felt that his very memory was dearer to me than any living being of my own sex. I know not what attaches me so closely to this child of nature, but I think that a great deal of my attachment depends upon his misfortunes and his untimely fate."

Next morning he continued his journey by Annan to a village named Springfield. While there he writes as follows :-

"I had wished to write my last report while inScotland in the village of Gretna or Gretney, 'celebrated,' as Denholm remarks in his Tour to the Lakes, 'in the annals of clandestine marriage.' When I reached this village I thought I had come to Gretney, and so entered an inn; but on enquiry I found that Gretney is a quarter of a mile off. It is a matter of little consequence, however. I have just finished my breakfast, which consisted of twopence worth of bread and a gill of whisky. The reason for my not taking a regular meal was that I had come to the end of one-half of the money which I had when leaving Aberdeen, and I wished to begin a new account on entering England. I have now travelled about 500 miles, and I have been thirty days on my journey. My expenses have been moderate, for I have seldom eaten oftener than twice a day, and I have just expended five pounds sterling. I have only an equal sum remaining, and with this I propose to go 
to London, to stay there upwards of a week, and to return to Aberdeen. I would readily undertake upon a wager to travel to London upon twenty shillings. But I shall not determine the sumonly I shall use the strictest economy. Bread and water will do very well for the greater part of my journey, for many a better man has lived a longer period than will be allotted to it upon worse fare. I have already travelled upwards of 500 miles, as I have said.

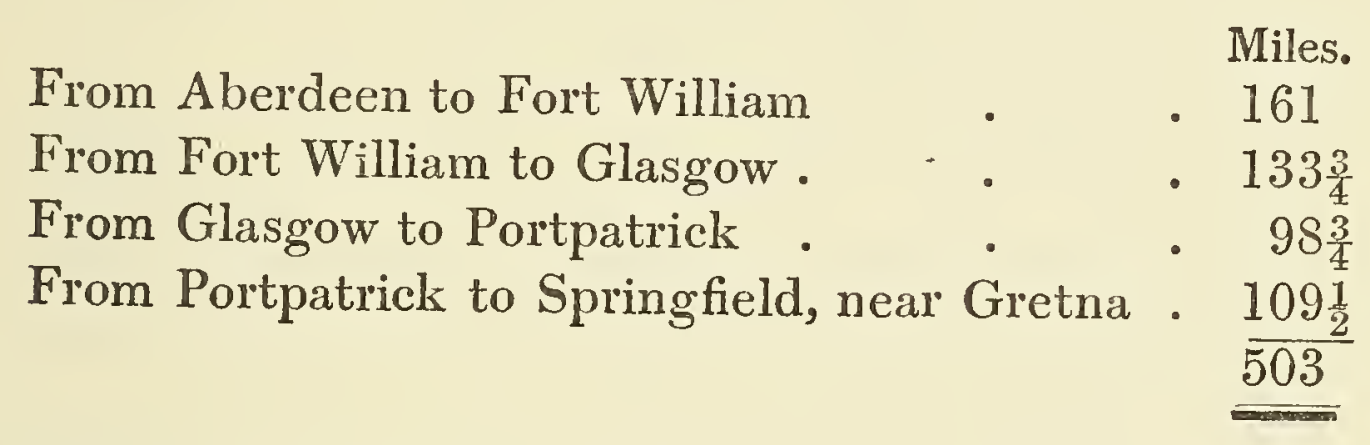

"The account of expenses may be seen in the Appendix. It has rained occasionally to-day, and I am wetted to the skin. I must continue to travel, however, till I get upon English ground, that I may not be obliged to break upon the remaining half of my money.

"I am not in a proper mood for making reflections, as may be readily conceived after what I have said. I leave Scotland without regret. Scotland is too wide a word for me, as the saying is. It is to the isles of the West alone that I feel attached and to the mountains of Albyn, and I pass from Dumfriesshire to Cumberland with perfect unconcern. Excepting the scenes of my youth the world is all alike to me. Its inhabitants are all alike my brethren.

\footnotetext{
"Land of brown heath and shaggy wood, Land of the mountain and the flood, Land of my__." .
}

Wherever I go my heart shall still be attached to 
thee. I dare not awake the remembrance of the days that have been, else we should have a scene like that at the grave of Burns. Then, Scotia, farewell! and if for ever-__"

After crossing the border on Friday, 8th October, he walked on to Carlisle, where he changed his Scotch notes for five of the Bank of England, assuming that being on English ground he would have no difficulty in regard to them when payments of smaller amounts had to be made. In Carlisle he searched about among the smaller inns for a lodging, but could find none, nor could he get change for one of his notes. So he proceeded on his way in the direction of Keswick until. about seven o'clock.

"I then entered a public house," he writes, "but was refused lodging; about half a mile further on I entered another-they had no bed. I ordered supper, however, for by this time I was hungry, having eaten nothing all the day but a twopenny cake. Previously to the good woman's preparing it, I informed her that unless she could give me change, she need not be at the trouble, as I had no silver. She said she could give me change, but on my mentioning that my note was of the Bank of England, a new difficulty arose, for none of them, she said, were taken in Cumberland on account of forgeries which had been made. It was in vain that I told them I had got my notes at the bank. Her husband said that I had indeed spoken like an honest man, but they had once been cheated and had resolved never to take a Bank of England note. I told them I should not have cared upon another occasion, but then I was hungry and 
fatigued and could scarcely proceed on my journey. No matter-it would not do, and on I trudged. ... At length I thought I was going in a wrong direction, judging by the position of the moon, which sent a few dim rays through a cloudy atmosphere. I was on a wrong road, but at length I came to some houses and was put right. Soon after I came to an inn, but here the beds were all occupied, and they were unwilling to let me sleep in an outhouse, and would not be at the trouble of preparing some supper for me. However I got directions in abundance. . . . At a cross-road I went to a farm-house to enquire. The door was shut. I found myself in the farmyard, and spying a cart shed went into it, and mounted a cart, where I lay down. I had not been very long there when I found a loft near me and got upon it. Here I found a bundle of wattlings, another of rushes, and a bit of mat I had carried along with me from the cart. So I put off my knapsack and laid the bag under my head on the wattles and rushes; I spread the ragged mat over my legs, and slept, but not soundly. About midnight my feet felt very cold. I put off my shoes and wrapped my feet in the mat. Wet shoes are good conductors and bad retainers of caloric. The mat answered better, for one foot soon got warmish, and that was enough for a strong chap like me. So I fell asleep, and when I awakened to-day the people were up and feeding their horses and poultry. I descended from my celestial mansion to wade again among the mire. I felt very weak, but did not experience the sensation of hunger. My hat was so crumpled that I could not get it put right, and my clothes were, and are still covered with dirt of various kinds. When I had proceeded about 2 miles I found an inn and entered it. There I breakfasted upon tea, bread, butter and eggs. But a dispute arose between the good man 
and the good woman about my notes. They said they believed they were perfectly good, and if I had any other note, especially a Scotch one, they would readily give change, but none of the Bank of England were taken, and they chose rather to lose the shilling for my breakfast than to run the risk of taking a bad note. This was tormenting, and I felt that I had done wrong in not telling them about it before I took my breakfast. The people were very kind and good natured, and wished me not to be concerned about the matter-for, said they, it is of no consequence and you are welcome to the breakfast. I am not sure but that my conduct verged upon dishonesty. However, I shall not act so again. ... It is now about eleven o'clock. I write this" (that is, the account of his experiences after entering England) "in the open air sitting upon a tuft of grass near the road."

He then walked on, and his next resting place was Keswick, but before reaching it he washed his stockings, shoes, and the legs of his trousers in a rill, and in the dusk arrived at Keswick.

"I was wet to the knees," he writes. "I was fatigued also, and my shoulders smarted with the straps of my knapsack. I felt uncomfortable after lying, half shivering and half snoring, in the loft of a byre the night before; and so, after eating a supper composed principally of beefsteak, potatoes, and apple pie, I deemed it proper and becoming and expedient to recruit my spirits and moistify my leather by taking a few drops of the creature. I ordered a gill of rum and ... I rolled myself up in the bed clothes and fell asleep, aye, and slept as soundly as a top. ... In the morning I crawled slowly from among the blankets, like a snail out of 
its shell, I put on my clothes and shaved and washed, and felt most gloriously comfortable. My note was changed at last, so I left Keswick, Saturday, 9th October, and proceeded on the Borro road."

The magnificent scenery of Borrodale impressed MacGillivray much, and he gives a very picturesque description of it, of his ascent of the mountains to the south-east, and of his descent in the dark into Langdale.

"The night was very dark," he writes, "and I could not even distinguish the stones on the road or the gates which crossed it. ... I knocked my shin against a gate, and soon after came to a house. As the night was extremely dark, I thought I could not do better than enter the house and petition for a bed in an outhouse or anywhere. When I entered I found a woman and a girl by the fire in a large and neat apartment. I told them I was a stranger, and had come from Keswick over the hills, and did not like to proceed further, as the night was very dark, and I would be obliged to them if they would allow me to sleep in an outhouse. The woman answered that they had a bed such as the family slept in, but perhaps I might not be pleased with it-as to sleeping in an outhouse it was out of the question. So I entered and seated me by the fire. I was asked what I would like for supper. "Is this an inn?' asked I, somewhat surprised. 'No,' I was answered."

Supper was at once set before him, after which he was shown to his room, where he found "an excellent bed." It was nine o'clock when he awoke 
next morning, and after breakfast he proceeded on his journey down Langdale-past Amblesidealong the east side of Windermere, and reached Kendal about five o'clock on Sunday afternoon, 10th October. He was much impressed with the beauty of Windermere and its surroundings, which he describes with warm appreciation.

He had now his first experience of a Sunday in England.

"I like not," he writes, "to see the Sabbath violated by people who profess the Christian religion. To-day, for the first time, I saw it violated, and I was shocked. In one place I saw boys flying a kite, and in another I met a parcel of pedlars. The bread and fruit shops were open everywhere, and on a lake" (no doubt Windermere) "I saw people sailing for pleasure. I like to see the Sabbath kept, even with puritanical strictness. This may be a Scotch prejudice - no, it is no prejudice. Devotion of one day in seven to religious exercises is absolutely necessary to keep in mind the chief end of our existence. It seems to confirm religious habits, and when the Scottish peasantry begin to think lightly of breaking the Sabbath, they will become less virtuous."

He wrote the above at Kendal on Sunday night, seated in an easy chair by a large fire in the parlour of the inn in which he found lodging, after applying without success at various other inns.

"At 10 o'clock," he writes, "I have now taken supper, and a pint of ale and a glass of rum, and a smoke of tobacco, and have sweated out at a large fire the water which I drank on the road to-day." 


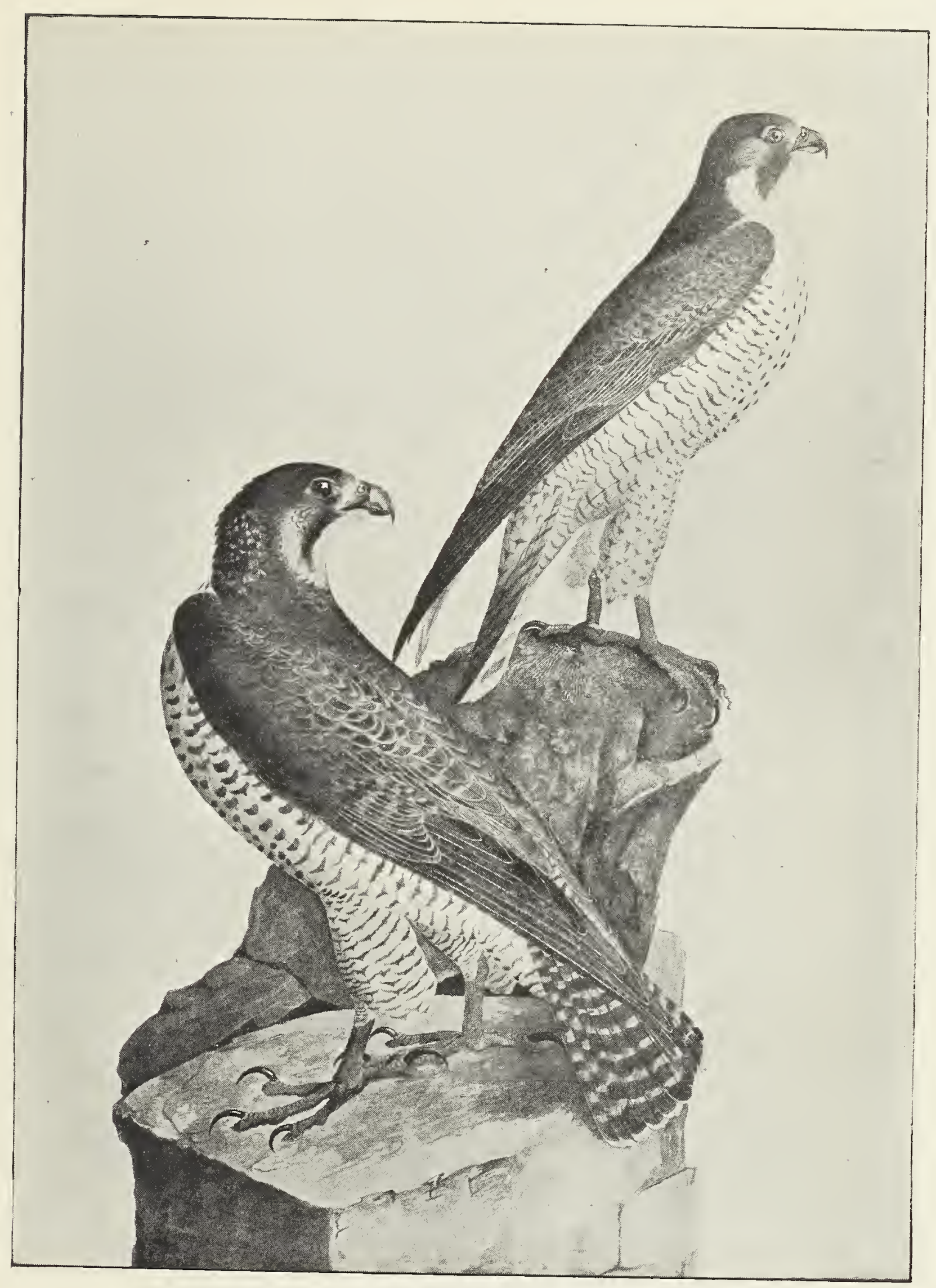

THE PEREGRINE FALCON, ADULT MALE AND FEMALE. (From a Drawing by MacGillivray in the British Museum.) 


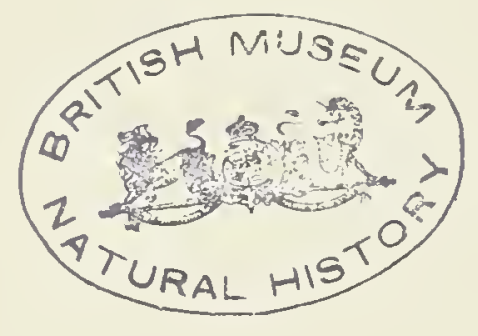


On Monday (11th) he was occupied in writing out his journal until about two o'clock, when he resumed his journey, and as he approached Lancaster he ascertained that there had been a great fair that day in the city.

"I felt assured," he writes, "in consequence I should not get a bed, and being desirous to see the town, thought proper to search for a sheltered place in the neighbourhood. I got over a wall and searched for some time, until, after wandering among the fields about half a mile, I fell upon a large misshapen house with two folding doors and gate. It was by this time about ten o'clock and the moon was up, but the sky being cloudy it was dark. I entered the house and groped about until I had made a complete circuit, and arrived at the door from which I had begun. No straw was to be felt and there was not a loft. The floor was soft and damp. However, I felt it more comfortable than a hedge side which I had tried."

So he lay down with his knapsack for a pillow and slept. He awoke about sunrise and saw he was "on the banks of a beautiful river, with the city of Lancaster and its superb castle about half a mile distant. I washed my face in the river and proceeded on my journey."

He then paid a visit to Lancaster, and found it crowded with visitors to the fair, after which he walked on to Horsley, where he spent that night. In the evening he wrote in his journal :-

"Làst night I slept on the clay floor of an outhouse. ... To-night I am comfortably seated in 

the parlour of an inn, and will probably sleep on a
bed."

He did sleep there, on a bed, that night.

The next entry in his journal is dated "Manchester, Wednesday, 13th October, evening," and he continues :-

"On entering the great city, I applied at several places for lodging, but was repulsed. In the house in which I now am, I was at first told that the beds were engaged; but there was a hesitation in the affirmation of the landlady which led me to think that she told a lie, and I was right. So a conversation ensued which ended in my admittance."

\section{He further writes :-}

"I had passed over such a desert of cultivated fields, hedges, and villages, and everything was so uninteresting that the remembrance of the scenery of Scotia came to my mind, associated with a thousand of agreeable images whose contrast excited melancholy and extreme impatience, and I had almost determined to take a seat in a stagecoach and finish my journey in a hurry. "Farewell Flora and farewell Fauna,' said I, as I descended the mountains of Westmoreland. I had not thereafter the company of these my favourites. I was out of trim too. My trousers are ragged and as nicely plastered with mire as the clay cottages of Cumberland; my shoes are nearly worn done, and my stockings are fairly finished. The roads were bad and muddy, and the weather was warm even to the extreme. But when I reached Chorley, and got seated by a blazing fire, and had smoked a pipe and supped, my spirits returned, and I thought I 
should walk to London although my stumps should be worn off to the knees.

"About 10 o'clock yesterday," he writes (Thursday, 14th of October), "I left Manchester, and such an abominable dirty hole of a town I never before saw. Narrow, irregular, dirty streets, misshapen brick houses daubed over with paint and whitewashing, hideous manufactories with their sooty, smoke-discharging chimneys towering among pestilential clouds that rolled over the city," etc.

To be out of the city and again on his way was a great relief to him.

"The sight of a stone," he writes, "marked with 'to London 182 miles' inspired me with fresh vigour, and for some time I trudged along as cheerily as if I had been within three hours' march of that great city, the goal at which my wild goose chase is to terminate."

He now walked on in better spirits, especially after he began to ascend the hills of Derbyshire, "where," he writes, "I even became so cheerful as to whistle a tune and to utter the expression with which this report commences, viz.: 'England, with all thy faults I love thee still.' Get thee behind me, Scotland, I said last evening."

He reached Buxton and spent the night (Thursday, 14th October) there.

"London is still," he writes the following day, " 150 miles. I propose to be there on Thursday at about two o'clock - that is, at the rate of twentysix miles a day. Ten shillings and sixpence is the sum to be expended on this part of my journey- 
that is one and twenty pence a day. I thought to have travelled more cheaply than I do, but I find it needless to torment myself with bad meals. If there were necessity for it, I know by experience that I can bear hunger as well as most people; but as there is not, I will even indulge my gluttonous appetite so far as to live upon about one-third of what the generality of travellers placed exactly in my circumstances, excepting in regard to the article pecunia, would expend and would think little enough. I once travelled 240 miles upon twelve shillings."

On Sunday (16th October) he is at Loughborough, Leicestershire, and writes :-

"I have advanced 50 miles since entering my last report, so that I am now within 110 miles of the great city of the south. On Friday at twelve o'clock I left Buxton. . . . Jupiter and Flora both smiled benignantly upon me. The weather was so fine that larks were singing as on an April morning, and I had not proceeded a quarter of a mile when I observed an unknown plant," and then he discovered other two that were new to him. "Everything conspires," he continues, "to render me cheerfulthe serenity of the weather, the agreeable keen nip of the air, the finding of these plants, and the feeling of perfect health and freshness-but above all the wideness of the prospect and the change in the nature of the country over which I had passed. . . . The idea of liberty was associated with the appearance of the country, and my heart bounded with gladness."

As he proceeded, however, the character of the country changed. 
On reaching Ashbourne he was again at a lower level, and writes:-

"I went into a shop and bought some cheese, for as my money was scarce I had half resolved to sleep out all night since the weather was not cold. It was dark by this time. I proceeded along a street and found that I had gone out of the London road. I was directed to it, however, and on finding it I went into a shop to buy some bread. A girl asked if I had got a bed. 'No,' said I, 'have you beds ?' 'Yes.' So I understood it was a lodging house for pedlars and poor stragglers such as abound in Galloway, and are intended for the reception of Irish vagrants. So I entered the kitchen and parlour, for I knew how cheap boarding and lodging are in such houses, and I expected some fun." His fellow lodgers he found to be "two Irish pedlars, an Italian picture and looking-glass vendor, a Don Quixote shoemaker who spoke not a word, the landlord and landlady, a couple of spindle - shanked, lanthorn - jawed creatures, two young girls, and a fat bull-dog."

There was a common table, at which all ate what they had brought with them. He had a good deal of interesting conversation with the Irishmen and the Italian boy, who, he says, "did not mix with the people, but looked like a lamb among wolvesor a lap-dog among terriers." When bed-time came, after smoking a pen'orth of tobacco, he ascended the stair with the Irishmen, who showed him his room with three beds in it, one of which was for the poor Italian boy. He says of him, "He has a good face. I felt attached to him 
because he was a stranger, and I could not help looking often at him. I wish," he continues, "I had the gas-lights of Glasgow to set them burning all night. My knapsack shall be in under my head -a good light and fair-play, I care na Deil's a bodle, but in truth I would rather encounter Auld Sootie than a parcel of Irish tinkers."

"Yesterday morning," he writes at Loughbor'ough on Sunday the 17th, "I rose before eight; the Irishmen were getting their breakfast ready. I got a pennyworth of tea and a pennyworth of sugar and twopence worth of bread, and breakfasted very comfortably. I then sallied forth. The weather was delightful."

He found some plants that interested him, and, on reaching Derby, he purchased a little bread and cheese, on which he dined in a field, after which he proceeded on his journey and passed through Leicester.

"I felt uncommonly cheerful and fresh," he writes, "and proceeded 4 or 5 miles furtherin all 15 or 16 . The sky became suddenly overcast and rain began to fall. A barnyard with some large haystacks appeared irresistibly inviting, and so I clambered over the fence and sat down by a stack, where I amused me for some time by picking oats. I then rose and searched for and got a convenient dormitory. At length I found a heap of straw, and making a hole in it, entered and lay down with my knapsack under my head and a handkerchief about it. The night was very cold and the wind blew through the straw, so that I could not sleep. The sky was clear and the keen- 
ness of the air indicated frost. So about two or three o'clock I got up and continued my journey. I met several people, but no one molested me. When the sun began to appear I found myself at the 80th milestone from London. I felt weak and my feet were sore, for the road was extremely hard. The grass was white with frost, and I was obliged to keep my hands in my pockets, as I had lost my gloves about three weeks before. About eight o'clock I got some bread in a village, and lay down by a haystack and ate it. Here I cut my thumb I believe to the bone. The weather soon after grew warmer, but I grew more tired, so that it was two o'clock before I reached Northampton. Here I dined by a dyke on twopence worth of bread and twopence worth of cheese, and then entered an alehouse, where I drank a cup and smoked a pipe, and read a piece of a newspaper."

The inn at which he next stayed he says was in a village called Graftonregis, between Northampton and Stoney-Stratford, 58 miles from London,

"so that I had walked 51 miles without sleeping. I supped upon cold meat and bread and a cup of ale, and after smoking a pipe and writing a little, got into bed. My bed was good, and I slept very soundly, as may be supposed. Let any person who wishes to feel what it is to sleep soundly walk 50 miles upon a very hard road and stay out a night in frosty weather, and then roll himself among warm blankets, and he will feel it. On Tuesday, 18th October, I rose about nine. My money was now reduced to thirteen pence halfpenny, and I was still 60 miles from London, excepting two. So I could not get breakfast and 
left the inn without eating anything. At a village some miles farther on I got a twopenny cake, and at Stratford a pennyworth of gingerbread and a pennyworth of apples, and trudged along. The weather was very fine; but the road was very hard and my shoes and stockings quite in tatters, so that the gravel was getting in and tormenting me. Nothing interesting occurred through the day. In the dusk I passed through Dunstable, where I stood for some time, like the ass of the Schoolmen, between two bundles of hay, unable to determine whether I should proceed or slip into an inn. What is the use of making resolutions, said I, if I cannot keep them? I went into a shop and got some bread and proceeded. About midnight I passed through the town of St Albans in Hertfordshire. Three miles further on I got tired and went into a park, where I lay down under a large tree. Here I remained about four hours. At length I heard cocks crowing and a herd of oxen in the road, and got up. But I felt weak, and my feet were excessively sore. The weather had changed, and it now rained pretty hard. I was, however, within 18 miles of London, and I had still threepence halfpenny in my pocket. So I got bread and an apple with my copper clinkum and crawled along. The rain continued. At the end of every two or three miles I was obliged to sit down to ease my feet. At length I got to Highgate about twelve o'clock, and soon after entered London. The rain poured down in torrents, and I was wetted to the skin. A bundle which I had directed to be sent me from Aberdeen was addressed to a $\mathrm{Mr}$. Cowie, a bookseller, No. 31 Poultry. So I managed, though with great difficulty, to crawl there. My parcel had arrived, and in it I found a letter from the Isles from Mary MacCaskell. This, however, did not ease my feet, which were intolerably sore, and I 
was obliged to stand for several hours for a servant of Mr Cowie who was to procure lodging for me. Mr Cowie is a Scotsman from Banff. I was directed to him by Dr Barclay. He was very kind and affable, and I dined with him. At length a room was got for me, and I proceeded to it with my baggage. After washing my feet with warm water, I got into a famous bed and had a glorious snoring bout till nine this morning (Thursday, 21st October), when I rose and breakfasted. I have now got into decent clothes, and I had need, as may readily be believed, after performing a journey of 800 miles on foot. : . I have now finished my journey, and I am satisfied with my conduct."

He appears to have been quite equal, notwithstanding the exhausted condition in which he arrived in London, to commence at once his visits to the British Museum and other places which specially interested him. He remained in London seven days, much occupied the whole time, and returned to Aberdeen by the steamboat, arriving there on 7th November 1819. The time occupied from his departure for London to his return to Aberdeen, was thus two months, while the distance which he walked on his journey to London was $837 \frac{1}{2}$ miles.

With regard to his visit to the British Museum, he writes in his journal :-

"I paid most attention to the birds-particularly to the collection of British birds. I was glad to find that most of my opinions regarding the genera of birds were deemed correct, for the improvements upon the Linnæan system, which had occurred to me on my journey through the 
Western Isles last year, were here realised; and I felt proud that I had been able to think for myself on such a subject and to think correctly too. However, I do not altogether agree with modern ornithologists, and possibly I may become some day the author of a new system. At least, I have the assurance to think so. . . .

"Ornithology is my favourite study, and it will go hard with me if I do not one day merit the name of ornithologist, aye and of botanist too, and moreover, of something else of greater importance than either."

It is most interesting to find that, at so early an age (then only twenty-three) he had been able to form so clear and confident an outlook with regard to his future. What a marvellous growth of mind he had undergone in the course of the twelve months which had elapsed since his visit to Harris the year before. He was then, as appears from his journal for that period, still struggling, although only with very partial success, in the effort to assert what he knew to be the strongest and best in him, amid social influences which, pleasant as they were, tended to divert him from his scientific pursuits. This second journal shows how much he had since then gained in extended knowledge of Nature, in the attainment to a more mature and readier judgment, in greater strength of will, in a steadier power of self-regulation and endurance in carrying out clearly defined purposes with reference to what he was coming to realise as his future life's work. 
This journal also shows that he had, since the Harris visit, attained to a finer and more poetic appreciation of all that was grand and beautiful in Nature. The mountains especially were drawing him to them with an ever-increasing fascination and intensity of reverential feeling. Although year after year, during his educational period in Aberdeen, he had passed on foot through various parts of the Scottish Highlands to and from his annual holiday in Harris, they never became commonplace to him. This is well illustrated by that splendid passage in his journal already referred to, which describes his night's experience on his way across the Grampians from Braemar to Speyside in the course of his walk to London.

These two journals taken together reveal to us the mind and life of the young naturalist as he then thought and wrought from day to day. They show him to have been a very unusual type; and it is only by a perusal of them in detail that one can fully realise what his youthful personality was. Yet the passages which I have quoted will afford the reader a fair idea of the main features of his mind and character.

Such as he was in his youth, he continued to be, in all that was strongest and best in him, throughout life. His dominating love of truth was the same from first to last, while his character for continuous persistent effort towards the attainment of clearly defined purposes, however discouraging the circumstances, and however great the obstacles, 
remained with him to the end of life. That marvellous walk to London was symbolical of all his after life. He quietly persisted and overcame in everything he undertook, and of that we shall find evidence in abundance as this narrative proceeds. His fine imagination, his warm poetical temperament, his reverence in the presence of Nature and of the Supreme Power which he always felt to be in and beyond Nature, became more mature as life advanced, and gave an elevation of tone to his scientific thought and work, while it added not a little to the attractiveness of his person and his teaching.

The two journals, in revealing with such fullness what the famous naturalist was at the time they were written, make us feel how much has been lost through the accidental burning of all the other volumes of his journal which he had kept with such regularity. Had they been still in existence, we would have had the means of knowing the man as he thought and worked from day to day, and from year to year, always quietly struggling on towards the best of which he was capable, always fitting himself into his position and duties for the time and making the most of them, often in circumstances of difficulty and discouragement, but never failing in persistent progress in his scientific pursuits, with corresponding ripening of the best qualities of his nature.

We have no information as to how he occupied his time on his return from London to Aberdeen- 
whether he still continued his medical studies, or had by that time entirely abandoned them for more congenial scientific work.

In the preface to his Rapacious Birds, after mentioning his visit to London, he writes : "Having been advised by a friend to engage in a kind of mineralogical speculation, I afterwards went to Edinburgh, where I had the advantage of hearing Professor Jamieson's lectures." Professor Jamieson was then the occupant of the Chair of Natural History in the University of Edinburgh, and the above passage makes it clear that MacGillivray had by this time quite abandoned medicine, and committed himself definitely to natural science. Who the friend was on whose advice he went to Edinburgh does not appear, nor have we any information with regard to the result of the mineralogical speculation. It is, however, known that Mr Walter Berry of Edinburgh, Dr Barclay's father-in-law, was then much interested in mineralogy; and it is not improbable that either he or Dr Barclay, if still then alive, was that friend. The precise date of his removal from Aberdeen to Edinburgh, however, is uncertain, though it must have been either in the end of 1819 , or beginning of 1820 , in time to admit of his attendance on Professor Jamieson's winter course of lectures.

His friend and former medical instructor, Dr Barclay, died of typhus fever on 20th December 1819, in the twenty-seventh year of his age. That sad event affected MacGillivray very deeply, and he composed 
a touching poetic "Tribute" to his memory, with a short sketch of his life and character prefixed to it. Its title was "A Poem on the Death of George Barclay, M.D." This he sent to Mrs Barclay, with a letter dated 4th March 1820.

The poem is in the Spenserian stanza, the same as that which Dr Beattie (the "Bard of the North," as he had then come to be designated) employed in his Minstrel. Beattie was a strong poetic influence in his day, especially in the counties of Aberdeen and Kincardine. He was a native of Laurencekirk, in Kincardineshire, became parish schoolmaster of Fordoun in the same county, and was afterwards Professor of Moral Philosophy and Logic in Marischal College and University, Aberdeen. The smooth flowing rhythm of his verse was very attractive to the ear, while the thought and sentiment of his poems were not unfrequently worthy of a more free and less formal poetic diction.

MacGillivray, in his sketch of the life of Dr Barclay, says: "Beattie is among my favourite authors, particularly in poetry." The local predominance of Beattie's influence and MacGillivray's affectionate regard for his teacher and friendly guide, naturally account for the peculiar diction and style of his tributary poem. It is in style Beattie's Minstrel all through, that of the early years of the latter half of the eighteenth century. But, notwithstanding its antiquated diction, there is in MacGillivray's poem much tender 
feeling and reflective thought. This is illustrated in several passages in which the writer pourtrays the character of his friend, and gives free expression to his feelings towards him. Referring to Dr Barclay's influence on him, the following passages occur :-

"The name which hallows this rude song

Has been to me a blessing and a light

To guide me on my weary way along.

"He saw my follies and reproved them oft,

Not in the galling tone of sullen speech,

But as a friend, in accents firm though soft."

The original poem is in the possession of $\mathrm{Mr}$ George Barclay of 17 Coates Crescent, Edinburgh, Dr Barclay's still surviving son, and is much valued by him as a family treasure.

Mr Barclay mentioned to me that he has a distinct recollection of his mother telling him of the first impression made on her by her husband's "wild Highland pupil," when as a young wife she went to Aberdeen in October 1816. MacGillivray had just then returned from his long botanical excursion, followed by his midnight journey to the sources of the Dee, to both of which I have already referred; and, as may be imagined, the condition of his clothing and general aspect when presented to Mrs Barclay, had suggested to her the appearance rather of a somewhat primitive Hebridean Celt than of an Aberdeen medical student. But, as she said, the fine qualities of his head and heart soon made him a welcome guest and friend. 


\section{CHAPTER III}

THE EDINBURGH PERIOD FROM 1820 TO 1831

The third period embraces the eleven or twelve years of MacGillivray's first residence in Edinburgh. This residence, however, was not quite continuous, as he writes in the preface to his $R$ apacious Birds that, after hearing Professor Jamieson's lectures,

"I then took myself to the outer Hebrides, where I hammered at the gneiss rocks, gathered gulls' eggs and shot plovers and pigeons until, finding the trade dull, I returned to the civilised part of the country. I now became Assistant and Secretary to the learned Professor of Natural History in the University of Edinburgh, under whom I took charge of an extensive and beautiful museum, in which I found occasional opportunities of making myself in some degree acquainted with objects which I might not otherwise have been able to examine. The late Mr Wilson, janitor of the university, who dealt extensively in birds, also allowed me to examine the specimens that passed through his hands."

By this time, however, he had more than himself to support, as on 20 th September 1820, before 


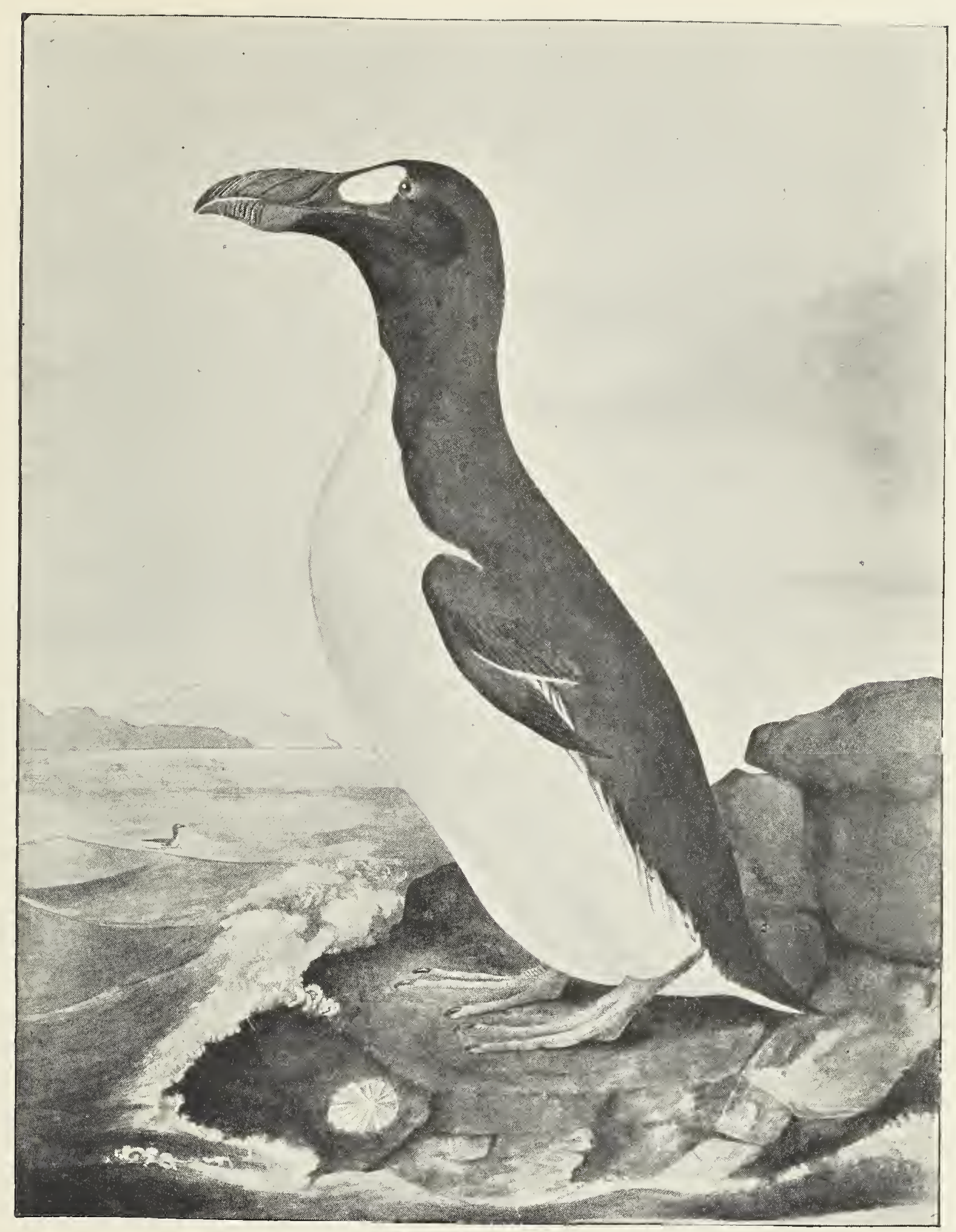

THE GREAT AUK.

(From a Drawing by MacGillivray in the British Museum.) 
$\left.y^{3}\right)^{E^{2}}$ 
leaving Harris, he had married Marion M'Caskill, who, as I have already mentioned, was a younger sister of his uncle's wife. His return to Edinburgh no doubt followed soon after that event, and the office of Assistant to Professor Jamieson, which he then obtained, with advantages resulting from it, not only provided the means of subsistence for himself and his household, probably in a very modest way, but afforded important opportunities for further cultivating and extending his knowledge of natural science. Important as these opportunities were, however, and the advantages derived from them, he had no doubt found that the duties of his position restricted too much his efforts for extending his knowledge of living Nature in a wider range than had hitherto been open to him. After some year's, therefore, he resigned his appointment under Professor Jamieson, and extended his wanderings far and wide, for the purpose of still further enlarging his knowledge of the habits and lives of his feathered friends. He supported himself, apparently, by contributions to scientific periodicals, compilations, and other miscellaneous literary work connected with natural science. 


\section{CHAPTER IV}

CONSERVATOR OF THE MUSEUM OF THE EDINBURGH

COLLEGE OF SURGEONS FROM 1831 TO 1841"HISTORY OF BRITISH BIRDS" - AUDUBON'S "BIRDS OF AMERICA," ETC.

MacGillivray further writes in the preface to his Rapacious Birds:-

"In 1830 I became a candidate for the conservatorship of the Museum of the College of Surgeons, which somehow, without my being acquainted with three members of that learned and most respectable body, and without soliciting the vote of one individual, I unexpectedly obtained, and continue to discharge the duties, not neglecting the opportunities of improving my anatomical knowledge afforded by the numerous skeletons of birds and other animals in that valuable collection. During the whole of this time, excepting about a year, when hope seemed almost to have deserted me, and when I had resolved simply to go through the drudgery of my duty, I have been more or less attracted to the study of ornithology."

In 1831 he was unanimously chosen from amongst ten applicants for the position of Conservator of the Museum, his immediate predecessor in that office having been the well-remembered Dr 
Knox; and thus began the fourth period of his life, which extended to 1841 .

The amount of work accomplished by him during that period, with all the care and perfection so characteristic of him, was marvellous, while on the results of it and of the many years of previous preparation his fame as an ornithologist mainly rests.

In the preface to the Rapacious Birds, MacGillivray gives the following reasons for publishing that work at the time he did-1836 :-

"I have," he writes, "shot, examined, described, and depicted a very considerable number of our native birds. With what. success my efforts have been crowned you may have an opportunity of judging some years hence. But as the period at which I propose to introduce to your notice my great work, as I may call it, is far distant, I have thought that you might not be displeased to receive an account of some of our feathered tribes, even if very imperfect, provided it should convey information not elsewhere to be obtained."

He then goes on to explain that the principles of classification of birds adopted by all contemporary ornithologists are defective, as being confined to the consideration of certain external organs only, such as the bill, the feathers, the claws, etc., and he proceeds :-

"But as the exterior alone of birds has hitherto occupied the attention of ornithologists in this country, and, indeed, in almost every country, I am unwilling to frighten away the student by a 
display of bones and muscles, blood-vessels and nerves. He will, however, I am persuaded, agree with me in thinking that if the bill be an organ of much importance, the parts of which it is merely the commencement must be so too. I have therefore ventured to describe in a brief manner the œsophagus, stomach, and intestines of all the species" (of the British Birds of Prey) "of which I have within these eight months been able to procure specimens for that purpose."

And all the species of rapacious birds, the consideration of which forms the subject of this book, are so described by him.

How beautifully picturesque and full of poetic inspiration are many passages in his works, describing the open-air life and natural surroundings of his feathered friends as he saw them in the course of his many wanderings in all seasons of the year, and at all hours of the day and nightespecially one passage in the Rapacious Birds titled "The Merlin"- the first in a selection of passages from his works which I give in a subsequent part of this volume. It is splendidly picturesque, most truthfully descriptive of all the birds, plants, and other objects which came under his observation on the occasion to which it refers; while it is aglow with the spirit of a true poet of Nature. I know of no other passage in any of his writings which illustrates so well what I have already said of him-that while he was eminently the man of science, he had also the heart and imagination of the poet and the painter, and 
the persistence of the explorer-qualities which, he says in his book on The Natural History of Deeside, "the naturalist ought, in his own person, to represent."

In addition to all the calls made upon him by his daily official duties as Conservator of the Surgeons' Museum and his other engrossing avocations, much of MacGillivray's time was occupied with important work which he undertook for the eminent American ornithologist, John James Audubon.

As Audubon came to be intimately associated with MacGillivray, a short account of him may be appropriately inserted here.

Audubon was the son of a French admiral who, in the early part of last century, had risen to that position from the avocation of a common fisherman. He had married in America, and there his son was born. The boy lost his mother while he was an infant, and was sent to France to the care of a kind stepmother, who took charge of his early education. While yet a boy, he spent much of his time in roaming about the woods and fields near his home on the river Loire, taking special interest in watching the habits of birds and in obtaining specimens, from which he made many drawings in a more or less primitive style.

On attaining adolescence, he returned to America, and wandering in the great forests there in search of birds became a fascination with him. Much of his time was thereafter spent in obtaining 
specimens of birds and making drawings of themin which art he rapidly improved, becoming more and more proficient with constant practice.

In the course of his wanderings, he accidentally met that eminent ornithologist, Lucien Buonaparte, who on seeing specimens of his drawings, encouraged him in his ornithological pursuits, and expressed so high an opinion of his art that the publication of his drawings thereafter became the subject of serious consideration with him. Publication in America at the time, however, was considered hopeless, and it was ultimately decided that a voyage to England should be undertaken with a view to their publication in that country.

The necessary amount of capital having been got together by the joint industrial exertions of husband and wife, Audubon sailed for Liverpool, taking with him a large number of drawings, with introductions to various men of position and influence, who might be interested in his work and be helpful to him. He landed in Liverpool in April 1826, and after spending some time in the West of England he proceeded to Edinburgh, arriving there in September 1826. He procured rooms from Mrs Dickie, 26 George Street, which continued to be his home while he was in Edinburgh during this and all his subsequent visits.

His strikingly picturesque figure, with flowing locks reaching to his shoulders, his eyes aglow with genius, his courtesy and simplicity of manner, and his unaffected kindliness of disposition soon gained 
him friends. Not many weeks had passed before he was received on terms of warm friendship by most of the leaders in the cultured society of Edinburgh. Sir Walter Scott, after his first reception of him, writes in his journal: "There was no dash, no glamour, no show about him; but great simplicity of manner and behaviour, slight in person and plainly dressed, wearing long hair which time had not yet tinged, his countenance acute, handsome, and interesting, but still simplicity is the predominant characteristic." Much interest was taken in his art. It was highly commended by everyone of taste and intelligence, and he received great encouragement in the promotion of the object of his visit. His drawings were at first exhibited in his own apartments in George Street, but afterwards in a room in the Royal Institution, which was lent to him for the purpose. The various learned societies vied with each other in receiving and honouring him as a distinguished guest, while he was entertained socially by many of the leading citizens of Edinburgh.

He arranged with Mr Lizars, the well-known engraver, to engrave and publish his drawings in successive parts-all the birds being full life size. The work was carefully superintended by himself, and the first part of his American Birds was issued by Lizars in 1827. As, however, a difficulty had been experienced by Lizars in the colouring of the engraved plates, the further publication of them was transferred to Mr Havell, in London. In order to 


\section{8}

CONSERVA'IOR OF SURGEONS' MUSEUM [CH.

procure additional specimens for his Birds of America and to make that work as complete as possible, Audubon returned to America in April 1829, where he remained about a year, constantly wandering in search of birds, collecting specimens, and making drawings of them. In April 1830 he returned to England accompanied by his wife, and bringing his additional specimens and drawings with him. After a short visit to London, where he found the engraving and colouring of his drawings going on to his satisfaction, he, with his wife, proceeded to Edinburgh, in order to arrange for the preparation and publication of a new contemplated work, entitled Ornithological Biographies. This work was to be devoted to descriptions of the birds in his drawings, with an account of their habits and habitats, and of the most interesting of his adventurous wanderings in search of them.

There was, however, a difficulty to be overcome-Audubon was not a technical ornithologist. In an entry in his journal, published a few years ago by his granddaughter, Miss Marion $R$. Audubon, he says that although he is "a poor writer" and "not a scholar," he is aware "that no man living knows better than I do the habits of our birds-that no man living has studied them so much as I have done," and that with the assistance of his old journals and memorandum books, written on the spot, he could "at least put down plain truths, which may be useful and perhaps interesting." "I cannot, however," he adds, "give scientific descrip- 


$$
\text { colwibugh. } 19^{\text {th }} \text { thue } 1834 \text {. }
$$

tect ver,

Oreg Reare to introduce foyou my

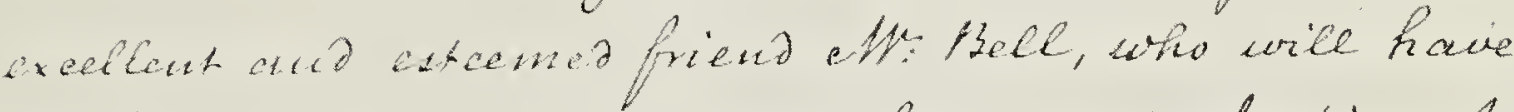
the fintout of wikiting you on hiveray to Indide. Ao

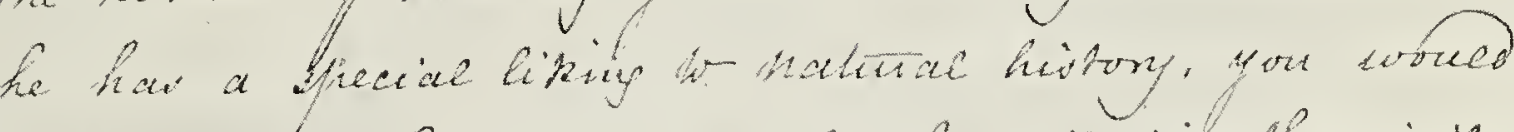

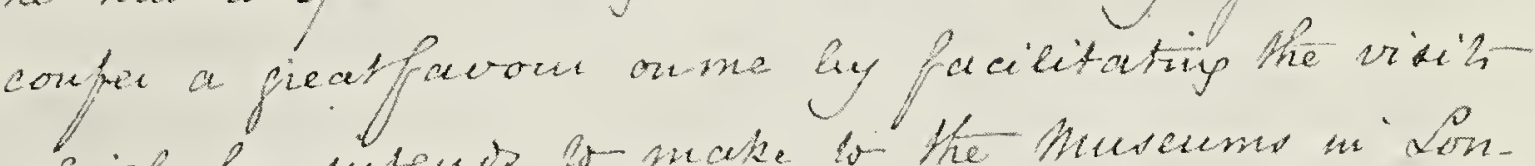

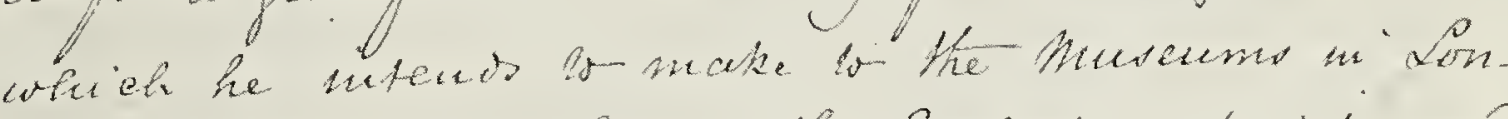
don, pactientarly that of ihe Bovtogical toristy; an

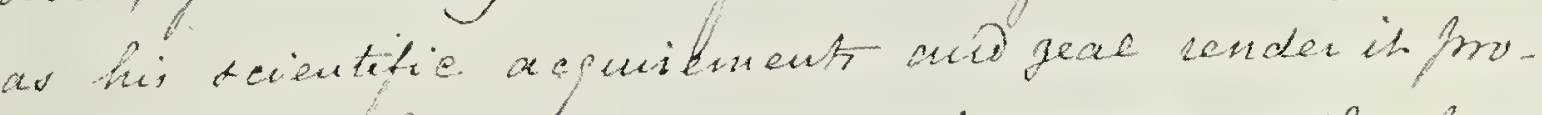
babee that he may atend out twowlege of the bo-

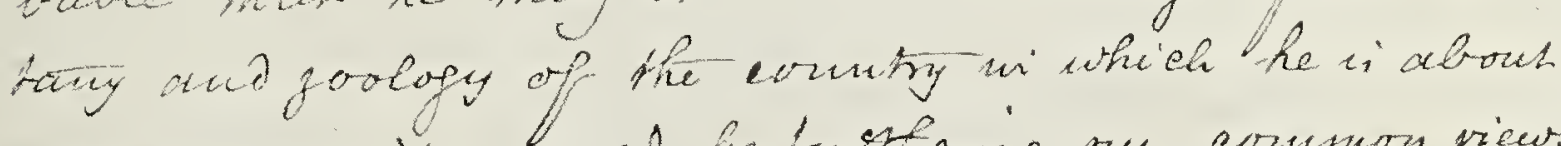

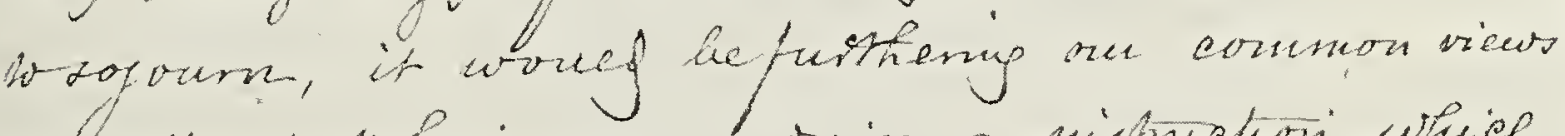

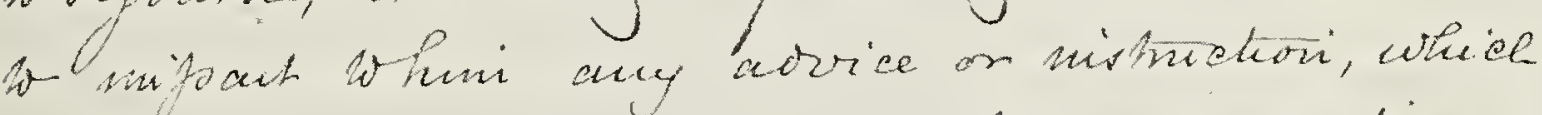
you Zory axpeniense and mecesfue mivestipation to wete quality you Wogre.

$$
\begin{aligned}
& \text { Chace the honom iste, thartir. } \\
& \text { your obevient Pervant } \\
& \text { If: ellachilioray. }
\end{aligned}
$$

\section{A REDUCED FACSIMILE OF MACGILLIVRAT'S HANDWRITING.}

(From a letter kindly lent by Mr Ruthven Deane, Chicago, through Mr J. A. Harvie-Brown, Dunipace.)

[To face $p .68$. 


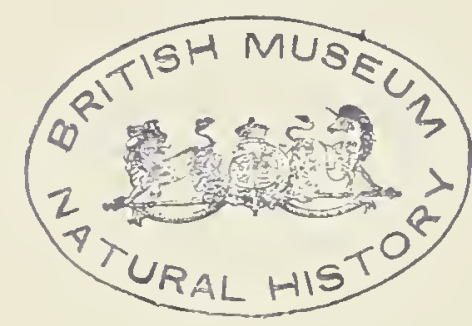


tions, and here I must have help." So it was then arranged, through the medium of Mr James Wilson, the well-known ornithologist, that the necessary help should be given by MacGillivray.

The two naturalists then met for the first time, and although no two men could in some respects be more unlike each other, yet no two men could have been better fitted, notwithstanding radical differences in mind, character, and habits of life, for friendly co-operation in the joint work about to be undertaken by them. Their general tastes and devotion to ornithology were alike, and they were alike in the perseverance and endurance with which each had in his own sphere for years pursued the object to which he was consecrating his life, counting no sacrifice too great for the acquisition of the necessary knowledge for its accomplishment. Again and again the pinch of poverty had pressed hard on both of them. They had each married young, and family as well as individual needs were at times met with difficulty. Audubon, however, with his early acquired accomplishments, his gracious manner, and the versatility and readiness by which he could, as if by magic, turn his accomplishments from time to time to account in procuring the needed funds at will, was much in contrast to MacGillivray's reticent, self-contained, self-reliant manner, and quiet plodding at such literary and scientific work as came to his hand.

In 1830, when he began his work for Audubon, he had not yet obtained the position of Conservator 
of the Surgeons' Museum, while he had some years before resigned his appointment as Secretary to Professor Jamieson, and Assistant Keeper of the Natural History Museum, in order to be able "to pursue with greater freedom his work in the fields." Audubon had for several years been well known among the élite of Edinburgh society, was highly respected by them, and while his friendship was valued on account of his estimable social qualities, his art was regarded as unrivalled in its excellence, specimens of it occasionally being parted with by him for considerable sums. MacGillivray, on the other hand, was probably unknown as yet, except to the limited circle of scientific men with whom he had come into contact. On these, however, his great scientific acquirements, and his other sterling qualities, had, by the time of the arrangement with Audubon, made a decided impression, and in his narrower circle his real worth was coming to be known and recognised.

Audubon knew much of the lives, habits, and external features of American birds-more than any other living man, as he said himself-but he knew nothing of their organisation, or of the principles of ornithological classification. MacGillivray, however, knew more of British birds than any other man then living, having seen and observed so much of them in his repeated wanderings. He was besides more learned than any other British ornithologist in the anatomy of birds, while his views in regard to the principles of classification 
were in advance of all other ornithologists of that time.

With regard to Audubon's capacity for scholarly composition, he certainly underrated it, as much of the writing in his journal is admirable in stylefrequently strikingly picturesque, and glowing with poetic inspiration.

MacGillivray's style is always strictly correct, without any affectation of elegance, and it never fails in clearness of thought, or in the choice of the most aptly expressive language, while, like Audubon, he also shows no small measure of poetic inspiration and artistic instinct. He was, besides, the accomplished scientist.

The joint work Ornithological Biographies was at once begun. "Audubon worked incessantly, MacGillivray keeping abreast of him, while Mrs Audubon rewrote the entire manuscript to send to America in order to secure the copyright there." So said Mr D. G. Elliot, in an address to the New York Academy of Sciences in 1893; while Dr Coues, in his Key to North American Birds, writes: "Vivid and ardent was Mr Audubon's genius, matchless he was, both in pen and pencil, in giving life and spirit to the beautiful objects he delineated with passionate love. . . His page is redolent of Nature's fragrance, but MacGillivray's are the bone and sinew, the hidden anatomical parts beneath the lovely form, the nomenclature, the classification-in a word, the technicalities of the science."

The relationship thus established between these 
two eminent men extended through nine yearsboth working zealously and in perfect harmony with each other until the work was finished-Audubon having during that period paid two more visits to America for the purpose of obtaining further information and additional specimens for his two great works.

The first of the five volumes of the Ornithological Biographies was published by Adam Black, Edinburgh, in 1831, while the remaining four appeared in $1834,1835,1838$, and 1839 respectively. In this last year a synopsis of the whole, entirely composed by MacGillivray, was also published.

In his introduction to the first volume, Audubon warmly acknowledges his indebtedness to MacGillivray for the part of the joint task contributed by him; and in the introduction to the fourth volume, he again refers to MacGillivray's work in appreciative terms, making special mention of the vast number of the specimens he had examined (fully 500), his anatomical descriptions, and his sketches illustrative of them. In the preface to the fifth and concluding volume, while referring with gratitude to the Edinburgh friends who had been especially helpful to him, and to whom he says he will ever feel deeply indebted, he continues: "The first and the best is William MacGillivray. I wish that you, reader, and all the world besides, knew him as well as I do;" and again, in referring to the arrival of his wife and other members of his 
family in Edinburgh for the last time, he says they found "my friend MacGillivray and myself up to the elbows among the birds which I had brought in spirits from America-I acting as Secretary, he as Prime Minister. Under his kind tuition I think "I have learned something of anatomy," etc.

On the joint work being thus so satisfactorily completed, Audubon, by way of a pleasant leavetaking, planned and carried out an excursion to the Scottish Highlands, which he had always wished to see, but for which time had not hitherto been available. This excursion he graphically describes towards the conclusion of the preface to the fifth volume. "When September," he writes, "had mellowed the general aspect of Nature, the long cherished desire of obtaining a glimpse of the Highlands of Scotland filled our hearts anew, and we resolved to visit the mountains and lakes so beautifully described by the illustrious Scott. The weather was as fine as we could wish. My good friend MacGillivray, by way of taking a holiday, accompanied us." The party consisted of himself, his wife, his son John with his wife and child, and MacGillivray. Their route was by steamer to Stirling, and thence to Callander, Loch Lubnaig, the Trossachs, Loch Katrine, Inversnaid, etc., and home by Glasgow, Hamilton, and the Falls of the Clyde. Audubon's description of the scenery in the course of the route is at times quite poetical, as well as finely picturesque, while it shows how entirely the whole party enjoyed the excursion. 
74 CONSERVATOR OF SURGEONS' MUSEUM [CH. IV.

In the same preface Audubon refers in touching terms to his approaching final departure from Edinburgh, as to which he writes: "What beautiful walks around that superlatively beautiful city. The oftener I have rambled along them the more I have thought with deep regret that now at last $I$ am bidding these walks, and the friends whom I know and possess there, a last adieu." So he left this country never to return; and when he was about to settle down on a beautiful spot acquired by him as his permanent home in the neighbourhood of New York, which he named Minniesland, he said, after a short experience of a city residence in New York, "I could not live in any city, except, perhaps, the beautiful Edinburgh," thus showing that he continued to retain pleasant memories connected with his life and his work there.

Although Audubon's work undoubtedly owes much to the "bone and sinew" contributed to it by MacGillivray, it is also clear, I think, that the gain by the arrangement between the two naturalists was not all on one side; and on merely glancing through MacGillivray's History of British Birds (the first three volumes of which were published almost concurrently with the later volumes of the Ornithological Biographies, viz., in 1837-39 and 1840 respectively), it will appear evident that he was considerably indebted in the preparation of that book to the information and experience gained by him through 
his work for Audubon, and especially to the great number of American birds examined, dissected, and described by him for the Ornithological Biographies. $\mathrm{He}$ refers over and over again in his History to important information received from Audubon, while he quotes freely from descriptions by him of American birds and their habits.

On the publication of his Rapacious Birds, his "first work," he dedicates it to Audubon, "in admiration of his talents as an ornithologist and in gratitude for many acts of friendship."

The ten years during which he occupied the position of Conservator, his duties to the Museum were discharged with the most conscientious care, and with perfect scientific skill and intelligence. His first year's work was especially arduous and laborious, and it severely tested both his physical and his mental powers. When he entered on his duties on 17th September 1831, the numerous preparations belonging to the College were partly in the old museum in Surgeon Square and partly in two other separate buildings; while their condition and arrangement were far from satisfactory. The present handsome building was just then being completed from designs by Mr Playfair, and the responsibility of the removal of the contents of the old buildings to the new one devolved on MacGillivray. $\mathrm{He}$ found the preparations in a very unsatisfactory condition - many of them having been badly prepared, badly put up, and badly arranged, while almost all were far from 
clean. He had them thoroughly cleaned and otherwise put into a satisfactory condition, and re-arranged the whole collection, re-labelling every article. The labelling of 4000 articles was of itself a most laborious undertalking, occupying many months. Almost all the labour, except the actual cleaning and the manual work of transport to the new hall, was done by his own hands. In one of his most interesting reports to the Curators interesting as throwing light on the capacity and character of the man - he says that he must practically do all the work himself, "as no benefit would be derived from the interference of others." The labels in his own neat handwriting are still to be seen attached to many of the preparations, which remain in the order in which they were left by him.

During the year 1832 the removal and rearrangement were completed; and the College, it is believed, recognises to this day the work then done, as of permanent value to the Museum-the system of arrangement adopted by MacGillivray being still adhered to.

The work thus accomplished by him was specially acknowledged by the College in terms that leave no room for doubt as to its efficiency and value, as appears from many of its minutes. In one, dated 2nd. August 1832, it is recorded that

"Mr Wood said there could be but one opinion 
as to the general assiduity and talent which had been shown by the Conservator in the very arduous task of removing and arranging the Museum, which he had performed so much to the satisfaction of the College. He therefore begged to move that the sum of $£ 50$, together with the thanks of the College, be presented to the Conservator for the extra labour he has had in the matter."

At the next meeting of the College (13th August 1832),

"Dr Gairdner, President, in absence of $\mathrm{Mr}$ Wood, proposed that his motion of 2nd August, regarding a grant of money and vote of thanks to the Conservator, be approved, as he believed it was admitted on all hands that Mr MacGillivray was most deserving of this mark of approbation from the College, especially as the motion proceeded from the Curators of the Museum, who were best acquainted with the nature and extent of his labours and with the manner in which he had performed his duties. The motion was unanimously carried."

The subsequent minutes of the College afford abundant evidence of the extremely satisfactory manner in which MacGillivray continued to discharge his duties as Conservator during the remaining eight years of his tenure of that office, never grudging time or trouble in the discharge of these duties in the manner most conducive to the interests of the College and to the entire satisfaction of that body.

His knowledge of comparative anatomy and of natural history the College recognised as being of 
special importance in connection with his duties in the Museum ; and by a minute of 21st March 1833 they authorise him to absent himself from the Museum on Saturdays, "for the purpose of enabling him to go into the country and give demonstrations on natural history."

A minute of 2nd August following bears that the Curators in their quarterly report to the College,

"desire to express their satisfaction with the state of the collection under their care, and with the skill and attention by which the duties of the Conservator have been performed, and that it appeared to the Curators that, as he is at present engaged in preparing the catalogue, considerable advantage would be derived from his being enabled to spend three or four weeks in London for the purpose of inspecting the museums there. $\mathrm{Mr}$ Brown moved, agreeably to the recommendation intimated in the report of the Curators, that the Conservator be sent to London at the expense of the College for the purpose of examining the museums there, with the view of preparing himself to adjust the catalogue of the Museum belonging to this College, which motion was agreed to."

The minute of 12th November contains the following passage from the Curators' report :-

"It will be recollected that the College, with the view to the preparation of the catalogue, gave permission to the Conservator to inspect the museums in London. He visited previously the University and Andersonian Museums of Glasgow, the collections of natural history in Liverpool, and 
the museums of Dublin and Bristol. In London he visited the various collections, taking such notes and drawings as may be of use in completing our own arrangements. He visited also the museum at Chatham. The Curators have every reason to be pleased with the industry and intelligence displayed by the Conservator in the tour which he has made."

The College approved of the report, and agreed that the Conservator should have the use of a clerk to assist him in making out the catalogue.

Fortunately, the journal of MacGillivray's tour of inspection of the museums has been preserved and is now in the library of the natural history department of the Aberdeen University. It is of much interest, and throws no little light on some of the more remarkable features of his character. Three or four weeks was the time allowed him by the College for the inspection, and he visited the museums in Glasgow, Liverpool, Dublin, Bristol, and London-numbering twenty-four in all, accomplishing the whole of that work, including his various journeys, from the time he left Edinburgh on 4th September until his return on 29th of that month (three weeks and four days), although there was then no railway to quicken his transit except on a visit from Liverpool to Manchester and back. It appears from the journal that he had gained all the information with regard to the different museums, the acquisition of which was the special object of his tour. The contents of the museums, the arrangement of the preparations, the mode in 
which they had been preserved, labelled, etc., and their condition generally, were readily taken in by him in all their detail, as well as in their general features, and were noted for reference in connection with his own work. He learned much that was of special interest to him, although apparently very little that was suggestive of improvement on his own ideas of museum classification and arrangement. Indeed, he comments very unfavourably on the condition of some of the museums which he had visited, while others drew from him warm approval.

The following are a few extracts from the journal, which are very characteristic of the man, and illustrate the keenness of his eye in at once detecting what he found to be wrong and in seeing what he felt to be worthy of praise.

Of the British birds in the Glasgow College Museum he says :-

"The birds are very clean and neat, but generally in bad attitudes. The beaks of two eagles were actually polished and varnished, and the legs and bills in general were painted, usually in tints unlike those of the parts in their natural state. The legs of birds ought never to be painted, for obvious reasons."

With reference to the natural history collection in the museum of the Liverpool Royal Institution he says :-

"The fossils are numerous and generally good. 
Quadrupeds ill stuffed-birds wretched. There is not one specimen in a characteristic attitude."

With reference to his visit to the Dublin College Museum he writes :-

"There is a considerable number of skeletons, but almost all uningeniously articulated, and in the most preposterous attitudes. About six are excellent, however. . . . In this department almost everything is in the most wretched disorder."

With regard to his visit to the Dublin Zoological Gardens he says :-

"The collection is good and infinitely superior to a museum of five times the number. These collections will in time teach zoological painters the characteristic attitudes of animals, of which Audubon and myself are the only persons who have succeeded in attempting to afford an idea in so far as regards birds. As to stuffed animals, they are altogether entirely and wholly absurd."

With regard to Montague's collection of British birds in the British Museum he writes :-

"It is fine on account of its extent, but does not contain ten well-stuffed specimens. When are we to see some improvement in this art? Surely it were better to give an artist twenty shillings for a fine specimen than five for a bad one."

With regard to the anatomical and pathological collection at the London University he writes:-

"The preparations are very beautiful. The 
82 CONSERVATOR OF SURGEONS' MUSEUM [CH. IV.

heads of the bottles are very neatly secured and painted in the usual way. The ticketing and numbering neat. Everything in excellent order and cleanly. The whole has a finished and beautiful appearance."

Of the contents of the museum of St Thomas's Hospital he writes very differently :-

"The preparations illustrative of comparative anatomy," he says, "are in general poor ; many of them are decayed, the collection is decidedly contemptible. In the other departments the preparations are in general good, but the objects are ill arranged, frequently crowded; in other cases the reverse. ... Everything bears the appearance of an old institution as much in need of a radical reform as a Scotch burgh.

Besides his comments on the museums there is much in the journal of interest otherwise-his geological observations, his picturesque descriptions of scenery and of life, his general reflections, and passages of humour, peculiarly characteristic of the man, all tend to enhance the value of the small MS. volume so neatly written in his own hand.

The minutes of the College, all through MacGillivray's tenure of office in its museum, contain evidence of its entire confidence in him, and they repeatedly record the College's admiration and appreciation of his work. The Museum, during his ten years' charge of it, was kept in perfection of order and cleanliness, while much was added to it 
which enhanced its value. Every addition (not a few by MacGillivray himself) was at once put into the most perfect state of preservation, and was fitted into scientific order. Nothing was ever left in disorder, and constant cleaning was rigidly carried out.

From a minute of the College, dated 31st March 1834, it appears that MacGillivray had then begun to give lectures on natural history, and he obtained special permission from the College to absent himself on Saturdays, "to admit of his giving these lectures and to have scientific excursions with his pupils."

There is an interesting and amusing paragraph in a minute of the College of 2nd August 1834, in which it is stated that the Curators in their report to the College " agree to a sentiment expressed by the Conservator, that it has been noticed to him that low and vulgar persons can derive no benefit from visiting the Museum, but that it was obvious to him that such a collection is calculated to remove many of their prejudices, and that without information all men would be low enough. Besides," he added, "such persons are the least disposed to handle anything."

In a minute of 3rd August 1835 it is stated that the Curators reported that the catalogue was now completed, and that all the preparations then stood in the order of it, and it is added :-

"This work, so creditable to the College and so 
calculated to increase the usefulness of it, has occupied so much of the Conservator's time and attention, and has been so materially advanced by his assiduity and by his judicious arrangements, as to merit some species of acknowledgment on the part of the College, and with this view the Curators recommend to the College to vote him a gratuity of twenty guineas, which was unanimously agreed to."

In the minutes throughout the remaining six years there are frequent references to the condition of the Museum, which was always in the perfection of order and cleanliness, MacGillivray's predominating views with regard to museums being that the order should be strictly scientific, and that everything should be kept scrupulously clean. During his whole tenure of office he seems to have been allowed an almost autocratic privilege in having his views carried out; the result always being the entire satisfaction of the College.

At last the termination of his career as Conservator of the Museum seems to have come about rather abruptly. It is recorded in a minute of the College of 16th March 1841, that the President had received a letter from MacGillivray, informing him that he had heard from the Marquis of Normanby that he had been appointed to the Professorship of "Civil and Natural History" in Marischal College, Aberdeen, and that he accordingly resigned the Conservatorship of the Museum as from the last day of April following, by which time he said he hoped it would be in perfect order for a successor. 
The minute of the College of 21st April following bears that, on the motion of the President, Dr Huie, seconded by Dr Maclagan, the College

"unanimously resolved to put on record the high sense which they entertain of the value and efficiency of Mr MacGillivray's services as Conservator of the Museum of the College for the last ten years, and to convey to him through their President their sincere congratulations on his appointment to the Professorship of Civil and Natural History in Marischal College, together with their best wishes for his comfort and success in that new department of public duty."

Thus ended MacGillivray's career in connection with the Edinburgh College of Surgeons, in the course of which he had shown in a marked degree those qualities which specially fitted him for a higher sphere of usefulness in connection with natural science, to which he had so zealously and exclusively devoted himself for upwards of twenty years; and now we come to the fifth and final period of his life's work.

His name had already become famous as an ornithologist by the publication of the first three volumes of his History of British Birds; but before referring specially to that final period, some account must be given of his other work during the ten years of his eonnection with the Museum.

His duties there-constant and arduous as they were, and much as they occupied his time and thought-formed but a part of the work which he F 2 
accomplished during that fourth period of his life. Besides his lectures on natural history, many contributions to scientific periodicals, including the article "Ornithology" to the seventh edition of the Encyclopcedia Britannica, the editing of the Edinburgh Journal of Natural History and Physical Science, from 1835 to 1840 , the editing of new editions of several books on natural science, a condensation of Alexander Von Humboldt's travels, the lives of eminent zoologists, Descriptions of the Rapacious Birds of Great Britain, published in 1836, which he called his "first work," although he had previously published many original papers, translations, and compilations, "all in the way of business," as he says. He also during the same period wrote a History of British Quadrupeds for Jardin's Naturalist's Library, Manuals of Botany, Geology, and Zoology, and the first, second, and third volumes of his History of British Birds-his "great work," as he calls it by anticipation in his preface to the Rapacious Birds, the remaining two volumes having been issued only shortly before his death in 1852.

The most important outcome, however, of his ten years' work consisted in the first three volumes of the History of British Birds, to which the patronage of Her late Majesty, Queen Victoria, had been graciously extended, and to whom the work was dedicated.

The object which he sought specially to accomplish in the publication of that work is 


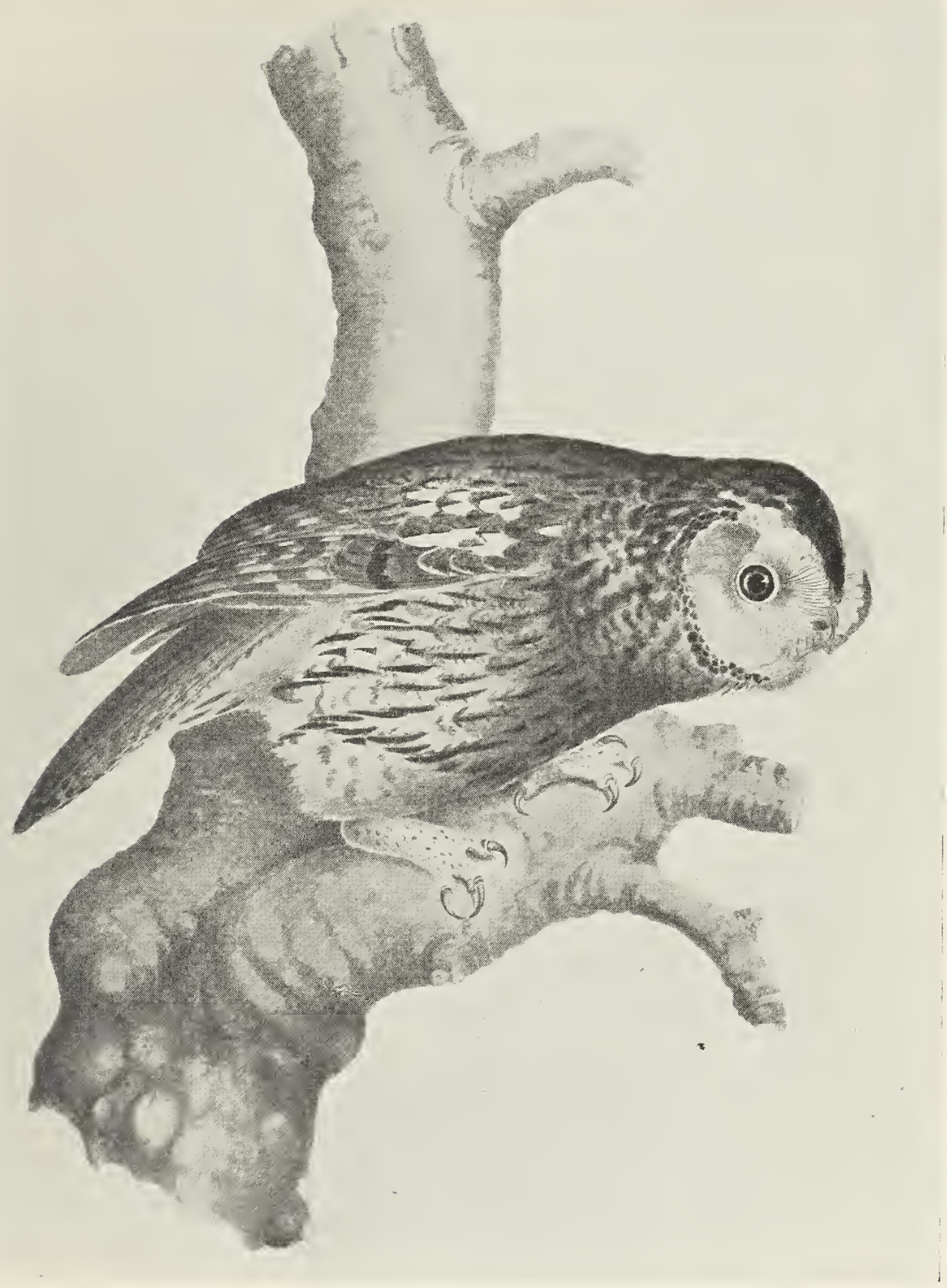

THE TAWNY OWL。

(From a Drawing by MacGillivray in the British Museum.) 


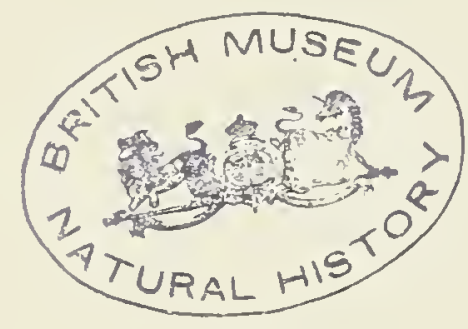


explained by him in the preface to the first volume as follows:- "The object I had in view when, many years ago, I commenced the observations recorded in this work was at some convenient season to lay before the public descriptions of the birds of Great Britain, more extended, and if possible more correct, than any previously offered;" and in the preface to the Rapacious Birds, he says : "Ornithology can be successfully prosecuted only by examining the internal structure, the external form, the actions and habits, the distribution and the various relations of the objects to which it refers;" adding, "all arrangements of birds hitherto published are merely artificial, inasmuch as in their details reference is had only to one or a few sets of organs." He further says he had not written without full preparation, having been at work for twenty years accumulating facts by his own observations in many fields, by numerous communications with other observers, by examination of many specimens, in museums and in his own possession, derived from various parts of the world, and by dissection of such birds as were available to him.

The publication of the three volumes of the History of British Birds formed the commencement of a new era in ornithology, and the result was to revolutionise "to a great extent that branch of natural science. It was in accordance with the principles indicated in the above quotations that the book was written, and its value from a 
scientific point of view consists in its having been so. This work had the effect at the time of raising its author to the highest position in Britain as an ornithologist. In the prefaces to these volumes he fully explains and vindicates the principles on which his system of classification, entirely differing from the classification of previous ornithologists, was founded.

But since that time the advance in ornithology, in every department of it, has been enormous. Many have followed the line of treatment initiated by MacGillivray, and most writers, since the publication of the Origin of Species, have gone much further, in the light of the principles of evolution and natural selection. Every organ and feature of the bird, both internal and external, has been made the subject of the most minute examination, with results directly bearing on the principles of classification.

$\mathrm{He}$ betrays oftener than once in his works a prophetic consciousness that, while he felt he was groping in the dark, the dawn of greater light was near; but how far he would have been able to accept the principles of Darwin may be uncertain. His belief in the separate creation of each species, and in its permanency as so created, appears to have been strong, when the introduction to the first volume of his History of British Birds was written. In it he says: "Species alone exist in Nature," while "genera, families, orders, and all the mediate sections of a class must ever remain fluctuating;" 
and that while species "are more or less allied to each other, they exist in an order conformable to the plan of their creation." His religious views, too, undoubtedly deep and sincere, were quite in harmony with his views as to the creation of species. He.saw God everywhere in Nature; and as his scientific knowledge deepened and widened, the more did the Creative Mind reveal itself to him in intelligent adaptation and design for the accomplishment of specific ends. Everything, as it existed, was to him the direct result of an original forth-putting of Creative Power and design, while his reverence for that Power increased as his scientific knowledge extended and deepened. Although the form of his religious belief, like the form of his poetry, was very much that of the preceding century, its reality and intensity were of his time, and peculiarly his own individually. Would his restricted scientific views as to species, with his form of religious belief, have prevented him from accepting the Darwinian theories of evolution and natural selection? Would he have been able, with his ardent love of truth and his capacity for clear insight into Nature, to accept the Darwinian theory of evolutionary progressive creation, in place of the view that all things were made at a beginning out of nothing, each species, age after age, simply reproducing itself, although subject to much and constant variation within its specific limitations?

It is not improbable that he would have got 
over the then existing wall of separation between the past and the present of all scientific systems. Indeed, notwithstanding his views as to species indicated in the above quotations, and his orthodox religious creed, there are passages in his Manual of Botany, published three years after his first volume of British Birds, which appear to show that his views had been undergoing a change, as in that work he says: "There is nothing absolutely certain as to species," that "species often pass into each other by gradations which render it impossible to draw a line of demarcation, and thus all species are more or less arbitrary;" while in his geological teaching he had quite abandoned those views as to creation which so hampered Hugh Miller to the last, and led to his fanciful theory of interpretation of the first chapter of Genesis. In the epitome of his lectures as dictated to his class in Marischal College, he says: "Species have not changed during historical times," apparently implying that they may have changed during longer prehistoric periods; and, again, in that epitome he says, "the most perfected animals appear to have been created last," thus assuming that there had been successive creations-not one only, once for all. $\mathrm{He}$ was absolutely free from prejudice, always kept his eyes open, and constantly insisted on ascertained fact as the only legitimate basis of theory; while his love of truth and strict adherence to it formed, it may be said, the backbone of his life and of his work. He was eminently worthy of the 
Gaelic name he bore, "Gillivray"---servant of the truth; and the publication of The Origin of Species would probably have been hailed by him as the rising of a new sun in the heaven of science, and as bringing the light for which he had been prophetically looking. He would probably have been able to see God's creative power in Nature not less clearly and reverently than before-creative by a never-ceasing evolutionary process, a continual progressive unfolding of the essential being of all existences-an endless change and growth of organic form, making clearer to him the full significance of those very principles of classification which he had already adopted, with a deeper insight into the facts of Nature on which they rested, and which, through the mind of Darwin, had come to the scientific mind of the age as a new and great revelation.

But besides the scientific aspect of the History of British Birds, that "great work" has other. features which will always preserve its interest and attractiveness to many readers who may be unable to enter intelligently into the author's scientific descriptions and deductions. The narratives of his excursions-often by night as well as by day; the difficulties encountered-at times. with no little danger, especially while scrambling among the rocks of the Outer Hebrides, or climbing the cliffs of Ben Macdhui; his descriptions of scenely-now overpowering in its ruggedness and grandeur, and again tenderly soothing in its soft and varied 
beauty, amid which he wandered in the pursuit of knowledge of the habits and modes of life of his feathered friends, are often extremely fascinating, and all the more so when such scenes are enlivened by a solitary raven on its crag, or by a couple of sea eagles wheeling about on wing high above his hiding-place, or by flocks of sea birds of all varieties wandering over a flat sandy shore, with the sea far out on a bright sunny morning, in search of their early meal, or by a grey and yellow wagtail, as seen by him on the banks of the Braid Burn one summer day while walking along its course.

"How pretty and pleasantly thou runnest," he writes, "along the sandy margin of the brook. The pattering of thy tiny feet can be heard only by fairy ears; so light is thy tender frame, which vibrates as if thy joints were too delicate and thy muscles too sensitive for thee to fix them for a moment in rest. The gentle breeze, that scarce bends the young grass, curves the long feathers of thy tail, and the sudden blast sweeps thee away quivering and emitting thy shrill notes. .... It is pleasant to me to gaze upon thee, thou marvellous epitome of mind and matter, so harmoniously organised."

But every feathered creature, from the most powerful and relentless bird of prey to the smallest and most harmless of the race, attracted his sympathy as he found it in its native habitat and congenial surroundings.

In his Natural History of Deeside the following 
very sympathetic passage with regard to the raven occurs :-

"It is now beginning to get dusky. The croak of the raven seems to warn us of the approach of night. Poor bird! He has little cause to harbour friendly feelings towards us; for fearful has been the persecution which he and his race have suffered, if not at our hands, yet at those of our kindred. Very seldom now is a raven to be met with, even in this wild track of mountain and glen : gamekeepers and sheep farmers with guns and traps have left but a very scanty residue of a once prosperous and respectable race. ... It is indeed a rare pleasure to hear the barking and yelping of that distant bird which from the red crags to the right calls aloud to his mate, perched behind us on that rugged ridge."

Here is another passage of tender sympathetic feeling with regard to the ravens at Loch Tulloch, from the same book :-

"The path leads along the base of the furrowed and stony declivities, which are of granite, coarse and reddish, like that of the opposite side. All along this passage, it was very pleasant to hear the ravens, in the crags of the opposite side, talking to each other in a great variety of accents, one answering the call of another. Poor fellows! If the glen were mine, I would give strict orders not to molest them, for next to the eagle, now altogether destroyed, the raven is the greatest ornament of such a scene. They continued croaking, barking, and yelping at a great rate until I had passed the end of the rock."

Indeed there was no bird to be found in all his 
wanderings which did not draw warnth of sympathy from his kindly heart; and there are many passages in his book on British birds, which, for picturesque beauty, poetic feeling, or tender sympathy with Nature, and every living creature that came under his observation, can scarcely be surpassed. Yet he never allowed his sympathetic feeling, or his appreciation of the pictiresque to interfere with his work as a scientific ornithologist. To learn the facts about the habits and lives of living birds was the main object of his many wanderings; and his power of imagination and sympathetic susceptibility, in place of hindering, helped much, in his case, to the readier and cleaser perception of those facts, and to his capacity for making them more vividly and attractively apparent, to others-to the non-scientific as well as to the scientific.

There is another interesting feature of MacGillivray's mind, which betrays itself in many passages of his "great work," as well as in his other works - that is an ever-present sense of the deep mystery of Nature and of the limits of his power of insight, however much he had been able to see farther than others of his generation. He was intensely worshipful at Nature's shrine--all his best thought and feeling often rising into reverential awe, and his heart overflowing with gratitude and thankfulness to the Author of all that beauty and glory, which constituted for him its supreme and abiding interest. 
"Let us humble ourselves," he writes in his Natural IIistory of Deeside, "that in contemplating God's works, we may ever see Him in the midst of them. If, in this temper, we traverse the valley of the Dee, and ascend the mountains from which the sources of that beautiful river gush forth, even if we discover little that may be of interest to science, we shall find much that may benefit our spiritual nature. And what would it profit a man, were he to solve half the mysteries of external nature, and yet be ignorant of the higher relations of his own being? Strange adventures, perils among rocks and Hoods, wonderful discoveries or magnificent theories, cannot be expected from a quiet journey to be made in one pair of shoes, with no other weapon than a hammer."

The illustrations in his History of British Birds, drawn by himself, and consisting principally of the beads and feet of birds, besides being scientifically acourate, are fine specimens of art, each being strikingly expressive of the character of the species of bird represented. As examples, nothing could be finer shan the head of the golden eagle, or of the sea eagle, or of the raven, or the magpie.

But these illustrations, good as they are, come faj. short of his water-colour drawings of birds in the British Museum. They are beautiful works of art. executed with great delicacy and care-in expression, in attitude, and in their natural surroundings, just as he had seen them with his own eyes. Yet they are little known outside the walls of the Natural History Department of the Museum. Modest as he habitually was, he did realise that 
there were things which he could do better than other people, and he spoke the simple truth when he said that, in his day, no one could draw a bird except Audubon and himself.

MacGillivray's last place of residence in Edinburgh, before leaving it for Aberdeen in 1841, was at No. 1 Wharton Place, now no longer in existence, its site being occupied by part of the buildings of the Royal Infirmary. His immediate neighbour was Mr Fraser, the successor of $\mathrm{Dr}$ Neill of Canonmills Lodge in his well-known, old-established printing business there. The MacGillivray, the Audubon, and the Fraser families were on terms of close friendship with each other; and the late Mr Alexander Fraser, son of MacGillivray's friend, then a boy, told me sometime before his death that he still remembered with pleasure the friendly meetings in one or other of the three family residences, and he specially mentioned one such meeting in Audubon's rooms when John MacGillivray (MacGillivray's eldest son), carelessly flourishing a stick, broke a glass case in which Audubon kept one of his ornithological treasures, to the great annoyance of the naturalist. $\mathrm{Mr}$ Alexander Fraser also told me that he, with John MacGillivray and John Audubon, then both young lads like himself, and afterwards eminent naturalists, were wont to go out on bird-shooting expeditions, and that on one occasion they were caught in Ravelston Woods, rather roughly handled by the gamekeeper, and had their gun taken from them. 


\section{CHAPTER V}

PROFESSOR OF NATURAL HISTORY IN MARISCHAL COLLEGE AND UNIVERSITY, ABERDEEN, 1841 TO 1852 - "HISTORY OF BRITISH BIRDS" COMPLETED-" NATURAL HISTORY OF DEESIDE AND BRAEMAR" -DEATH.

As already mentioned, MacGillivray in 1841 entered on a new and extended sphere of eminent usefulness, as Professor of Natural History in Marischal College, Aberdeen, a sphere for which he was specially qualified, and which was altogether congenial to him. Then began, as I have said, the fifth period of his life. His chair included zoology, geology, and botany, this latter being a separate lectureship. All of these branches he had made subjects of special study, and had published, as before mentioned, a manual on each of them while he was in Edinburgh. His scientific many-sidedness specially fitted him for the varied character of his work in his new position, while that position at the same time afforded him opportunities for still further self-development, in accordance with the main bent of his mind and in the lines of his

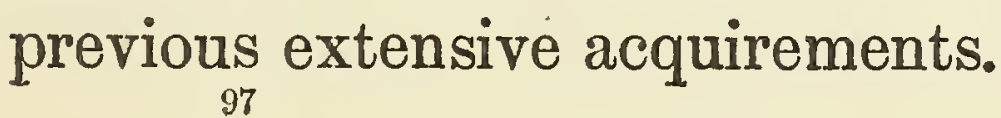


In Marischal College he found himself in contact with young inquiring minds, to instruct and to guide which was henceforth to be the principal business of his life. He devoted himself to this work with all his energies, mental and physical, and with a warmth of sympathetic interest not always found in the occupants of professorial chairs. There was earnestness and reality in all his work - in his lectures, in his excursions into surrounding districts, with his students in search of zoological or botanical specimens, or for examination of geological phenomena. These excursions often involved long and fatiguing walks, but his youthful companions, inspired by his spirit, always felt that what they had gained in knowledge from discoveries made under his guidance, in instruction then received or illustrated, or in pleasure from his kindly and courteous companionship, much more than compensated for the fatigues undergone.

MacGillivray brought new life into his chair, while the specially interesting nature of his lectures and the attractiveness of his personality drew to his classes many students, whose curriculum did not include the subjects of his teaching. Even brother professors, unable to resist his magnetic influence, were not unfrequently seen on the benches in front of him. The late Professor Blackie, then occupant of the Humanity Chair in Marischal College, actually enrolled himself as one of his students!

An example of MacGillivray's special aptitude 


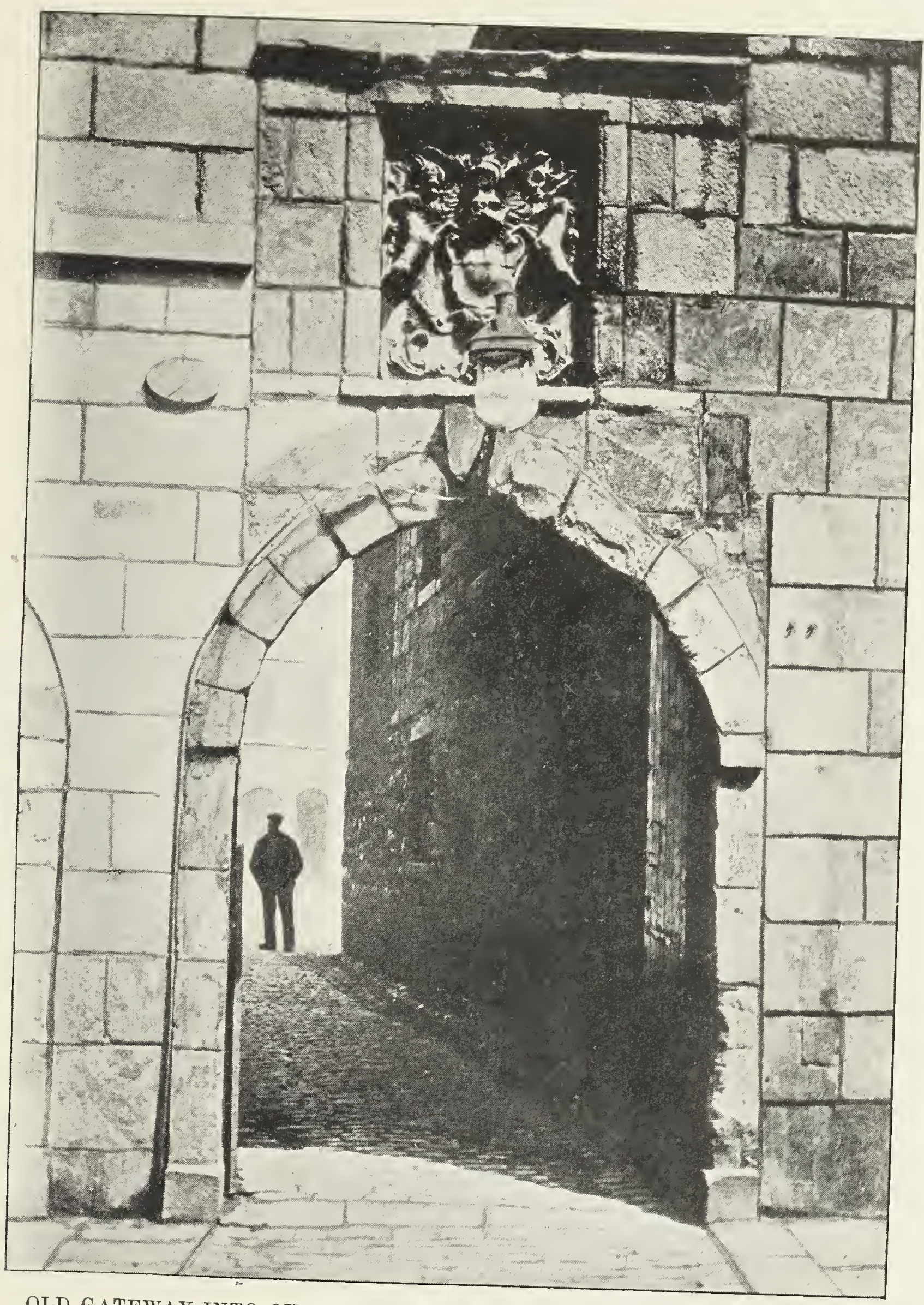

OLD GATEWAY INTO QUADRANGLE OF MARISCHAL COLLEGE, ABERDEEN, WHERE MACGILLIVRAY TAUGHT.

(From a Photograph kindly lent by Mr G. P. Duffus.) 

for work connected with his chair, and of the rapidity and careful accuracy with which he was able to accomplish it, was the preparation and publication, within two years of his appointment, of his History of the Mollusca of the North-East of Scotland. That work includes, with full descriptions, upwards of 300 species, all of which, except one, had, he says, been carefully examined by himself, while he had gathered two-thirds of them with his own hands-about twenty being new to science.

In the work of collecting he was aided by members of his own family, by students, and by friends resident in various parts of the adjoining districts, all of whom, inspired by him, were more than willing to contribute to his work any aid in their power.

In his preface to that book he remarks :-

"I present it" (the book) "with confidence to the public, because I am conscious of having produced it with great care, and because I think it will be useful." It was intended, he says, for his pupils and persons commencing the study of mollusca; and on that account, he adds, he had made the descriptions fuller than usual, as he was anxious "to induce them to go beyond mere nomenclature, and to make themselves acquainted with the structure and relations of the objects described."

He further observes, with justifiable but modest pride and prophetic forecast, that it was the "first zoological work that has emanated from the 
University of which I am a member, and I cannot but look upon it as indicating the not distant dawn of an era destined, I trust, to produce investigations, the importance of which will tend to give our city a rank, certainly not yet acquired, among those distinguished for the cultivation of natural history."

That prophecy has to a large extent been fulfilled, and it is mainly through his work and inspiring influence that it has been so.

MacGillivray occupied his chair eleven years, discharging his duties with the energy, intelligence, and independence of view which formed so essential features of his character.

In the course of his many excursions and otherwise he accumulated a large collection of zoological specimens, which he arranged into an excellent private museum, with the scientific order which was so natural to him. That museum was used by him to great. advantage as illustrative of his teaching, and it is now the property of the Aberdeen University.

His students always held him in the greatest respect, and many of them were warmly devoted to him. He was accustomed to treat them more as friends than as pupils; and one of his former students, in a letter to me, writes of him as follows :-

"I had a very great regard for him not only as an ornithologist but as a man. He was exceedingly 
lovable and undoubtedly the first ornithologist in Europe, and we were all proud of his fame. One thing always made a great impression on me: he treated his class as men and gentlemen, and we reciprocated his action. It was far otherwise with some of the professors.

"Fis interest in the habits of his students was remarkable. If he saw a good student careless he would remonstrate with him privately; while earnest attention gained his favour. With his rapid power of observation he could detect even a temporary lapse from diligence. His lectures were carefully written out, and he dictated an epitome of them once a week. Now and then he gave out a subject for an essay, say 'The Sparrow,' and he indicated a preference for a paper bearing on its habits and life on the street and on the wing. As an examiner he was patient, tender, and gentle, unwilling to say an angry word. He would rather help out the hesitating student; but it was easy to see that carelessness was an abomination to him."

Another Aberdeen student of his day, but who was not in his class, lately a professor in a Canadian university, writes of him to me as follows :-

"He was about my own height" (rather below medium stature), "firm of step, erect of gait, as he trod the pavement of Broad Street or wound his way through the Gallowgate to the old Town; great of reputation among British birds, and tireless, pedestrianising with his class among the hills and heather of Deeside. He could walk the most active of them into limp helplessness, and remain as fresh as at the outside of the march." "Keep your knees bent as you climb a mountain. You thus avoid having to raise your body at each step," 
was his advice to another student when accompanying him in a hill-climbing expedition.

Others of his former students also refer to him in terms of warm eulogy, those features of his character which appear to be most prominent in their memories being his eminence as a scientist, especially in ornithology, the attractiveness of his lectures, with his happy mode of illustration, his readiness to undertake any work, however arduous, in the interest of his science or his class, and unfailing kind consideration of his pupils.

Here is a delightful and warmly appreciative record by Lady Geddes, widow of the late Principal Geddes of the Aberdeen University, of some of the most beautiful features of MacGillivray's character and personality which could have been revealed only in the intimate relations of a perfect friendship :-

"It gives me pleasure to recall the old days, when we had the privilege and happiness of intimate intercourse with Professor MacGillivray and his family. Though far in the distant years, his figure still stands clearly before me, and I share the regret of his biographer that no authentic portrait is available as an introduction to the Life. When first we knew them the family resided in an old house with large garden, close to the Cathedral of St Machar, Old Aberdeen. We had a summer home across the river Don, which flows near, and our house stood in the crook of the crozier, revealed to St Machar in his dream as the place on the riverside for his church. The group of fine sycamore trees at our house interested MacGillivray 
greatly, and we liked to hear his views as to their age and possible purpose, for we longed to know their history. The Professor's botanical excursions with his students brought them often to the river, on their way to Seaton grounds, where wild flowers abound, and where they had permission to botanise. On these occasions, the party was rowed across in our river boat.

"Though not of a commanding figure, he was, in these days, alert. There was about him a modest dignity, and his manner was courteous and kindly. The countenance was sensitive and gentle in expression, but shaded by a persistent sadnesscharacteristics which drew towards him the affection of his students. Many of these became very distinguished men, among others Matthews Duncan, who rose high as a London medical man, and Thomas Keith, the celebrated surgeon. Another, the Rev. Dr Wisely, still survives in Malta; and I have heard all speak with devotion of their Professor. If it be a test of the great teacher to inspire enthusiasm and love of work, then MacGillivray seemed to be endowed with a double gift. My brothers were of the band who followed him, and one of them made a fine collection of shells, still preserved in a cabinet by the family. I think Keith did the same. A favourite excursion by the lads was to the fisher quarter, where they waited for the arrival of the boats, and secured specimens for a few pence. They often got some rare prize, and I remember even now, their return on one occasion with a large rare bivalve. The fisher folk believed the lads to be medical students, and begged them to prescribe for any invalid; and "Thomas Keith told me, with roars of laughter, that a fisherwoman would not let him go till he had prescribed for her child; so he said, 'I advised a poultice of warm tea-leaves, as that at 
any rate could do no harm.' This is amusing as being 'first aid' from a man who became such a benefactor to humanity.

"I was often requested by MacGillivray to examine shell sand with a microscope-for the very dust of the sea was dear to him-and I frequently found small new forms of great beauty. All were eager to work and discover something new.

"I remember one evening at a party in MacGillivray's house, the drawing-room door was thrown open, and a form in uncouth garb and scant of manners bolted into the room and held out some new specimen to the Professor, who received the lad with the same courtesy as if he had been an invited guest. An onlooker, on one occasion, remarked that if the Professor's daughter were to discover some new ugly insect, her father would likely make her name mother to the 'Guloch.'

"I attended one course of botany under MacGillivray, and his delicate and expressive hands, as he touched the plants, were remarkable. He once said when he handed specimens to each, that ladies were afraid to examine them minutely, for fear of soiling their hands. He made all most clear and interesting to us.

"During the winter session, after his lectures in Marischal College, he often called on us, and he enjoyed a talk round the fireside. He was rather reticent in conversation, but now and then there flashed out some humorous remark, showing his keen observation and knowledge of the human heart. I never heard him discuss religious topics, but like good and wise men, he was tolerant and kindly to others, and evidently reverent in his attitude to the great, mysterious, eternal verities, as has been the mood of many great scientists. For sanctimonious hypocrisy I heard him onee 
express his contempt. An agnostic whose irreverence was no secret to clerics and laymen, and whom MacGillivray knew well, died, and the last offices were performed by a clergyman. MacGillivray happened to look in on us after the ceremony, and said with indignation: 'Would you believe it, this pompous body of a minister prayed as if the dead man had been a saint.'

"As the years went on, we saw that his many cares and the stress of work were leaving their sad traces on a frame not naturally robust, so that he rather stood aloof from general society, but when he chose to be with friends, they welcomed his presence, so full of quiet charm. I sometimes thought that the very birds and creatures, whose life and ways he studied, lost their fear of man, and allowed him to get nearer them, for we know the strange perception animals seem to have of those who love them.

"Too soon MacGillivray was called away from those he loved and had to leave behind, and too soon for the studies he did so much to advance. It is a pleasure to those who knew him that a life so strenuous and useful should be placed beyond the reach of forgetfulness.

"If the few memories I recall help to bring his interesting personality more clearly before those to whom his reputation is dear, it will be pleasing to one who still cherishes the memory and friendship of a great and good man."

There appears to have been much in MacGillivray's considerate and kindly manner towards his students, which strikingly accords with Dr Barclay's treatment of him as his pupil. The two men were evidently much alike in the essential features of their character, and in all probability 
the influence of the kind friend and dutiful teacher left an impress on MacGillivray's mind which time never effaced, and which more or less influenced for good his after life.

In the autumn of 1850 he spent a holiday of about a month with his son Paul and his eldest. daughter on a pedestrian excursion to the upper part of the valley of the Dee and Braemar, his main object, as he explains in his last written book, The Natural History of Deeside and Braemar, having been to examine the "geological structure of Braemar, its Alpine vegetation, and to a certain extent its zoology."

The manuscript of that work, which had been completed by the author as if for publication, was after his death acquired from his family by the late Queen Victoria, and was printed by Her Majesty's command for private circulation.

Full details of the excursion and of its results are given in that book, which, besides its scientific value, is in several respects the most interesting and fascinating of his works. There is an unpretending simplicity in its style, while not a page is without interest, resulting either from the attractiveness of the personality of the narrator, as it comes out in connection with every detail, however trivial in itself, or from the pleasant surprise at the unexpected discovery of some Alpine plant, or the observed effect of a mass of eruptive rock as bearing on the geological character of the district, or from a strikingly picturesque 
view, or from an incidental reflective thought associated with the aspect of an object or scene which had specially impressed him, in which he gives utterance to his deepest thoughts or breathes out his most tender feelings or his holiest aspirations. There are more of such passages in that book than in any of his other works within the same compass. His sense of awe in the presence of the Great Mystery of Nature appears to have deepened. Religious thought and feeling had grown in him to greater maturity, and had come in a sense to dominate his science and his life, yet not so as to prevent him from seeing the facts of Nature as he had always seen them, or from drawing from them without bias the deductions which they appeared to him to warrant.

In his preface to that book he says :-

"If the Valley of the Dee has many a time been traversed by the wise and the learned, the man of science and the man of wit, the poet, the painter, and the tourist, it is equally instructive to the "naturalist, who ought in his own person to represent all these."

In his case the ideal naturalist was realised, for he combined all these characteristics in himself. He was eminently the man of science; he had the heart and the imagination of the poet and the painter, and he was the patient, plodding pedestrian tourist, easily accommodated with lodging and food wherever he went-in his earlier days sleeping 
at times under the open canopy of heaven after supping on a piece of oatcake and a few mouthfuls of water from a spring.

It would do injustice to most of the finer passages in the book to attempt to quote them partially, but one-a very touching passage near the end-can be so quoted without such risk:-

"The Divine Providence," he says, "has rendered my path pleasant to me in the rugged corrie, in the thick wood, and in the green valley; has prepared friends to forward my views, to protect me under their hospitable roofs, and instruct me by their conversation; has restored me to health and preserved it to me; has enabled me to accomplish the purpose of my journey, and filled me with gratitude now that I approach its termination."

It is believed, however, that although he felt at the time that he had benefited in health by the excursion, the fatigue to which he had subjected himself had been really detrimental to it. $\mathrm{He}$ became so ill a few weeks before the end of the College term of 1850-51, that he was obliged to relinquish his class duties for the remainder of that term, these having been undertaken for him by $\mathrm{Mr}$ James Farquharson, one of his most accomplished students, afterwards the Reverend Dr Farquharson, for upwards of forty years the late much-esteemed parish minister of Selkirk. MacGillivray was unable to enter on his class duties for the session 1851-52, and the same gentleman 


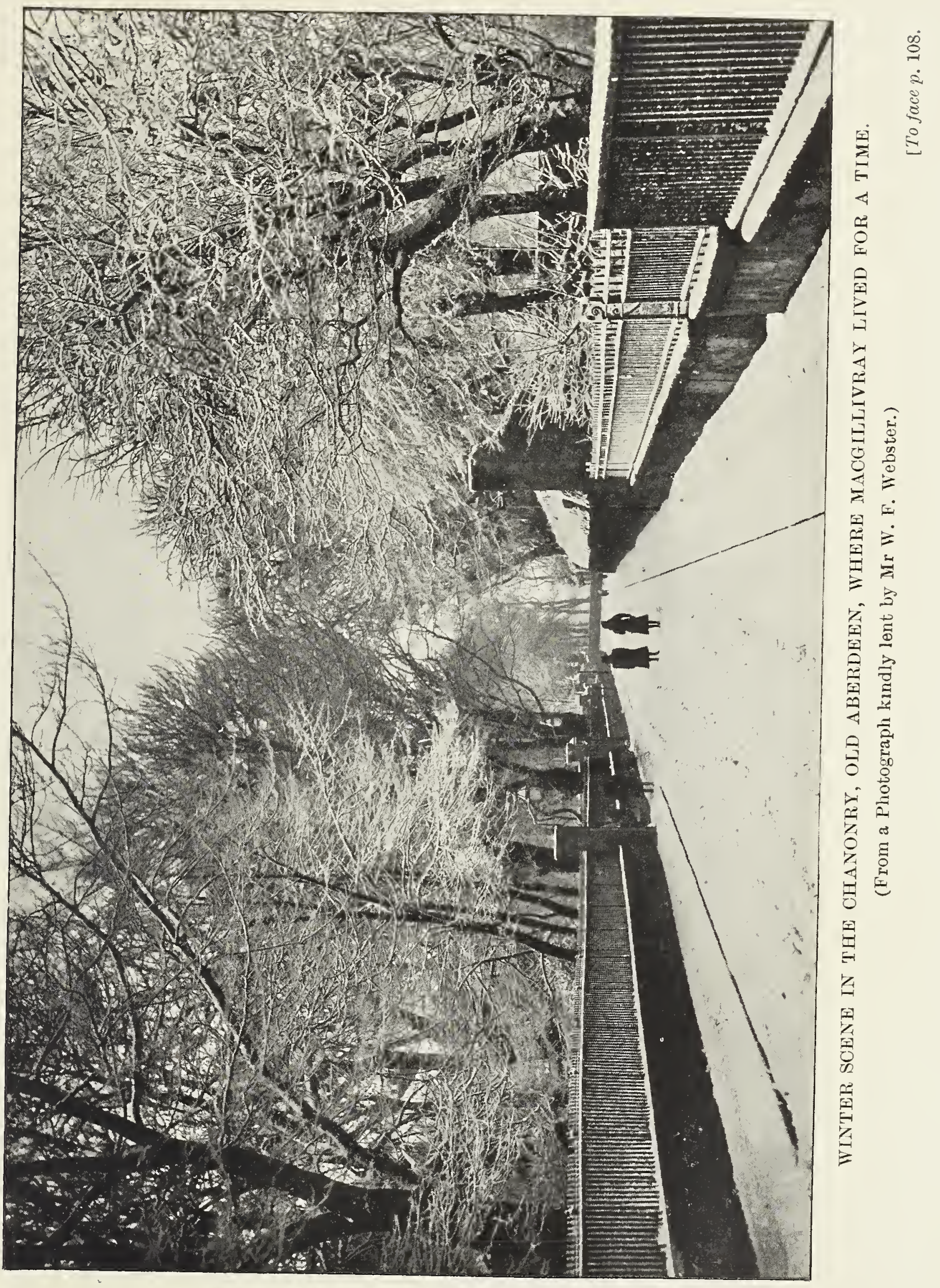




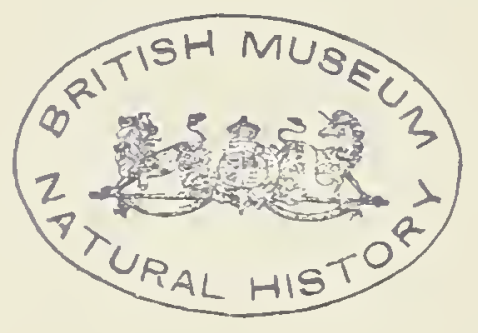


acted as his substitute again for the whole of that session. Accompanied by his eldest daughter, he went to Torquay for his health in the autumn of 1851, and while he was there his wife died suddenly in Aberdeen in February 1852.

On 8th March following, when still at Torquay, he published the fourth volume of his History of British Birds-just fourteen years after the issue of the third; and in the preface to it he makes the following touching reference to his position at Torquay at the time :-

"As the wounded bird seeks some quiet retreat where, freed from the persecution of the pitiless fowler, it may pass the time of its anguish in forgetfulness of the world, so have I, assailed by disease, betaken myself to a sheltered nook where, unannoyed by the piercing blasts of the North Sea, I had been led to hope that my life might be protected beyond the most dangerous season of the year. It is thus that I issue from Devonshire the present volume, which, however, contains no observations of mine made there, the scenes of my labours being in distant parts of the country."

The fifth and concluding volume was published on 31st July of the same year, after his return to Aberdeen, and on 8th September following, 1.852, he died in his residence in Crown Street of that city. He was buried in the new Calton Cemetery, Edinburgh, where his wife and two children had previously been interred.

The "Conclusion" at the end of that volume is calmly but deeply pathetic. In it the writer says :- 
"I have been honest and sincere in my endeavour to promote the truth. With death apparently not distant before my eyes, I am pleased to think I have not countenanced error through fear or favour. Neither have I in any case modified my sentiments so as to endeavour thereby to conceal or palliate my faults."

That "Conclusion" forms a most touching "Finis" to all his life's labours. It shows that he then realised, in quiet, self-possessed consciousness, that the end of his life's work was near, while his unquenchable love of truth and profoundly reverential recognition of the Creator of all that organic life which formed the subject of his untiring investigations-come prominently out in it. That conclusion is given as the final extract from his works in this volume, and as the most appropriate ending to it.

It is difficult now to realise what Professor MacGillivray's loss to natural science was then felt to be-the loss of "the most eminent ornithologist in Europe," as he has been designated. The loss, too, of a man who was so devout, so generous, so self-denying, so warm-hearted, so painstaking, so energetic, and so conscientious in the discharge of duty, and in the carrying out of any purpose to which he felt he had a call-who can tell what that loss was except those who had the privilege of personal relationship with him as scientists or as friends, or as members of his own bereaved family! He had thirteen children, several of whom died 
in infancy or childhood. His two sons, John and Paul, became eminent in natural science. John was naturalist on three scientific exploring expeditions sent out by the Government, viz., (1) that of the Fly, commanded by Captain Blackwood, to Torres Straits and the Eastern Archipelago, to which expedition he was appointed in 1842, when only eighteen years of age, and from which he returned in $1846 ;(2)$ in the end of the same year the Rattlesnake expedition, under Captain Owen Stanley (Professor Huxley, then an assistant surgeon in the Royal Navy, being also of the staff); and on his return from that expedition in 1850 he wrote an account of it, which was published in 1852 ; and (3) later in that year he was appointed to the Herald expedition to the coasts of South America and the South Pacific, under Captain Denholm. He, however, left the Herald on its arrival at Sydney in 1855, and thereafter devoted his life to scientific explorations in Australia and the Pacific Islands. His constitution ultimately giving way from exposure and the fatiguing nature of his work, he died at Sydney in 1867. It is said that he left journals of his expeditions and work of exploration, including amongst much else the results of special observation and study of the habits of the aborigines. These journals are said to be still in existence in Sydney, and there can be no doubt that there must be much in them that would be of extreme interest to scientists as well as to many others. It is therefore hoped that if 
they do exist, they will yet be permitted to see the light of day.

Paul also settled in Australia, and became an eminent surgeon there, but latterly devoted himself almost entirely to natural science, and made a large collection of specimens, which is now in the Museum of Natural History, Melbourne. He died a few years ago, and a monument has been erected at Bendigo, his former residence, to his memory. A third son, who died early, also showed a strong predilection for natural science, and, had he lived, might, it was believed, have rivalled his two distinguished brothers. So that the love of natural science was strong in the blood of that family.

Dr Donald William MacGillivray, a younger brother of the Professor, followed the medical profession. He was educated for it at the University of Edinburgh, living in family with his elder brother while attending the classes there. After taking his medical degree in Edinburgh he returned permanently to the Hebrides. He at first settled for the practice of his profession and for farming in South Uist, but the late Mr Gordon, the proprietor both of South Uist and the Island of Barra, who entertained a warm friendship for him, offered him the tenancy of the large and important farm of Eoligary in Barra, to which he removed, and there carried on extensive and successful farming for many years, at the same time giving the inhabitants of the island the benefit of his medical advice gratuitously. He was much trusted and highly 
respected by the islanders, and indeed by all who had the privilege of any relations with him; and when he died at Eoligary in February 1886, in the seventy-seventh year of his age, he was much missed and sincerely mourned. He, like his eminent elder brother, was interested in the ornithology of the Hebrides, as is also one of his sons, Mr William Lachlan MacGillivray, now of Eoligary, who has a fine ornithological collection there, and has made not a few presentations of birds and eggs of special interest to the Edinburgh Natural History Museum. 


\section{CHAP'TER VI}

MACGILLIVRAY'S SCIENTIFIC WORK : AN APPRECIATION

\section{INTRODUCTORY}

As the preceding biographical sketch shows, MacGillivray was for the most part a selftaught naturalist. We do not know of any decisive nurtural influences, giving him an impulse towards Natural History, so we have to assume that he had by inheritance a "love of Nature," and a scientific mood. We are on sure ground when we say that the former was fostered, by his being a country boy, and the latter by the influence of teachers and friends during his University course. Perhaps the tramps across Scotland at the end of session after session-for he always walked from Aberdeen to the West Coast to get a boat, at Glenelg, or some such place, that would take him to Harris - strengthened the interests and aptitudes that made him so pre-eminently an openair naturalist.

He was doubtless influenced by Prof. Jamieson whom he heard and assisted in Edinburgh; but the man was made before that. It is also certain that he found in Audubon a congenial spirit and a great 
encouragement, and that his museum-work in Edinburgh, first in the University and then in the College of Surgeons, helped to develop the detailed thoroughness which is so characteristic of his best work, the History of British Birds.

We do not know much in regard to the twenty years of MacGillivray's life in Edinburgh, between his marriage in 1820 and his appointment to the Chair of Natural History in Marischal College, Aberdeen, in 1841, but it was marked by an extraordinary industry. He arranged, and catalogued, and added to the Museum of the College of Surgeons; he issued a Manual of Botany, an abridgment of Withering's Arrangement of British Plants, a Manual of Geology, a History of British Quadrupeds for Jardine's Naturalist's Library, a condensed narrative of Humboldt's journeys, entitled The Travels and Researches of Alexander von Humboldt, and a book on the Lives of Eminent Zoologists. From 1835 to 1840 he edited the Edinburgh Journal of Natural History and Physical Science, and evidently wrote a large part of it. He collaborated with Audubon in preparing his Ornithological Biographies, contributing with the pencil as well as with the pen. He also wrote Descriptions of the Rapacious Birds of Great Britain. Meanwhile he was devoting most of his time and strength to the History of British Birds, of which the first three volumes appeared during these arduous years.

"By his talents and industry he had won for 
himself a front rank in natural science, but with small means of supporting his family; and the appointment to the Chair of "Civil and Natural History" in Marischal College in 1841 must have brought a welcome relaxation of the strain." ${ }^{1}$

MacGillivray often said that his life had been very rich in friends; but it is difficult, now at least, to say definitely that he owed much to any, except to his fellow student William Craigie and to the young physician, George Barclay, under whom he began the study of medicine. We are inclined to think that his success was in the main the natural outcome of innately fine abilities, sharpened by enduring hardness in his youth, and developed by strenuous self-discipline. For MacGillivray's life well illustrates the soundness of an often forgotten ancient counsel, which recommends patient preparation as a condition of lasting achievement:- "Prepare thy work without, and make it fit for thyself in the field; and afterwards build thine house" (Proverbs, xxiv. 27). What cannot but be regretted, however, is that MacGillivray did not live longer in the enjoyment of the house that he had built. For he only held his professorial chair for eleven years, and he died when he finished the fifth volume of his great book on British Birds.

1 "Natural Science in the Aberdeen Universities," by Prof. J. W. H. Trail, M.D., F.R.S., Aberdeen Quatercentenary Studies, p. 169. 


\section{The All-Round Naturalist.}

Looking from a distance of more than half a century on the scientific work of William MacGillivray, we have as our first impression that he stands for a type rapidly becoming rare-the allround naturalist. For, while he has left his deepest mark on ornithology, he took all natural science for his province, and does not seem to have been embarrassed. This all-round type is rare now, for scientific analysis is carried deeper, and the area within which an investigator can claim competence has been proportionally narrowed; so that, from amid our modern specialisms, we look back with almost incredulous surprise on the fact that MacGillivray was a well-equipped geologist, botanist, and zoologist, and that he taught all the three sciences with conspicuous success.

Nor does the difference between the old and the new naturalists relate merely to range of knowledge but to range of interest. All natural happenings were grist to MacGillivray's mill ; and even when the birds became paramount, it was rather that their fascination had become greater, than that his interest in plants or rocks had become less.

The all-round naturalist is seen, not so much in the fact that the ornithologist wrote a manual of geology and another of botany-for necessity has provoked many similar tours de force, though not always so dexterous as MacGillivray's - it was seen 
in his whole walk and conversation, and especially in his Natural History of Deeside. This work, indeed, shows his synthetic outlook to the highest advantage. It is a regional survey, precise and detailed in parts as every floristic and faunistic and geographic study must be; but its chapters compose into a picture, in which flowers and birds and rocks and weather are seen in perspective and harmony. As we read it we feel that the author saw Nature whole. It is significant that Alexander von Humboldt was one of MacGillivray's heroes, and that the Scotch naturalist should have given a year of his life to preparing an authorised account of the German's travels and researches (1832). Perhaps it is not going too far to say that the influence of the author of Cosmos remained with MacGillivray, for it was characteristic of both that they were able to look out on all orders of facts with keenly intelligent eyes, that they pointed forward to Darwin in the success with which they realised the complexity of inter-relations in Nature, that they tried to correlate peculiarities of fauna and flora in an area with the actual environmental conditions, and that they had an artistic as well as a scientific sense of the "physiognomy" of different regions.

We are not, indeed, comparing the scientific importance of MacGillivray's "simple journey" up and down the valley of the Dee with that of. Humboldt's travels in South America, but we are convinced that the two naturalists had the same outlook and the same methods: 
"A single-minded man," MacGillivray writes, "may by the right use of his eyes, anywhere that the sun shines, and the winds blow, and the rains fall, find abundant matter for observation and instruction.... The world is everywhere replete, not only with wonders to exercise the imagination, but with truths to improve the judgment. Even on the border of the most frequented paths are many things travellers have passed by unheeded or unexamined; and, if the Valley of the Dee has many a time been traversed by the wise and the learned, the man of science and the man of wit, the poet, the painter, and the tourist, it is equally instructive to the naturalist, who ought in his own person to represent all these characters."

It was in this mood that he told the story of his rambles, and the book, fascinating to those who know the ground, and remarkable for the beauty of some of the word-pictures, remains a fine pattern of what a regional survey should be like. $^{1}$

\section{The Open-Air Naturalist.}

MacGillivray was brought up in the country, and throughout his life he was at home there. During his studies in arts and in medicine he spent most of his summer vacations in the Hebrides. Of his long walks in later years the biographical sketch has told us; even at his busiest he would make time for a tramp over the Pentlands, or up Deeside.

1 Many have expressed the wish that this very rare book should be reprinted, but much of its geology at least.would require modification, and there are few who would care to begin tampering with the beautiful story. 
The modern student-victim of his times-is apt to develop the vicious habit of cerebrating only in the presence of print; the boy who came from Harris to King's College more than a hundred years ago had the habit of thinking in the open air. Professor Trail writes of him :- "During the vacations, and, when possible, during the sessions also, he took every opportunity to watch the life of birds and other animals in their natural surroundings, and to seek out and study plants, minerals, and rocks, from the sea coasts to the wildest recesses of the mountains. In his writings there are many passages that tell of the delight shared, whenever possible, with his close friend, William Craigie. An artist in words, as well as with pencil and brush, he depicts most vividly the fascination of such pursuits, and of the scenes into which they led him; and scarcely less evident in him is the longing to aid others to acquire the pleasures that meant so much to himself." This is well set forth in the biographical sketch, but we wish to emphasise the fact that, keen dissector as he was, MacGillivray was at his best in the field.

Professor Patrick Geddes has well said that "Nature-Study is the culture of the habit of observing and thinking for one's self, and at one's best, without books or helps, in presence of the facts, and in the open air," and we believe that MacGillivray came near the height of the naturalist's calling in the direction of this definition. In the preface to the first volume of British Birds he 
explains that it had been his ambition for twenty years to provide descriptions more detailed and more correct than any previously offered:

"To accomplish so ambitious a purpose, I judged it necessary to direct my attention to the living objects themselves, rather than to their skins in collections, or their portraits in books, to follow them in their haunts, observe their manners, procure unmutilated specimens, carefully examine all their parts, and thus be enabled to bring forward facts that had been entirely overlooked, and place others in a light in which they had not previously been viewed."

To some zoologists field work has seemed a necessary but irksome condition of subsequent laboratory work; to MacGillivray the laboratory work was a means to making the field work more intelligible. He points out, for instance, that the dissection of the alimentary system throws light upon the habits and haunts of the bird. By his thorough anatomising he made field work more significant for those who have neither inclination nor aptitude for anything else-and the restriction is an entirely legitimate one. But for the serious student, who would be a scientific ornithologist, MacGillivray's advice is clear and wholesome:

"Let us betake ourselves to the fields and woods; let us traverse the hills and valleys together; let us there study our favourites, pursue them from brake to bush, procure as many as we need, and returning to our homes, inspect their exterior, look closely to their bills, feathers, and 
feet, and not resting content with this, open them up, examine their internal organs, and record as much of our observations as we may judge useful to ourselves and others."

Later on he points out that while the open-air study of birds is very delightful, it is not easy :-

"The observer of habits must perform laborious, expensive, and sometimes dangerous journeys, and after all his exertions, may count himself singularly fortunate if he has succeeded in discovering some interesting facts previously unnoticed."

When we remember MacGillivray's devotion to anatomy-for his diligence in dissection was extraordinary-we are almost startled at times by the vehemence of his insistence on Open-air Natural History :-

"Is there a man so dead to Nature that, regardless of the leafy woods, the green fields, the gliding brooks, the rugged rocks, and the wave-washed shores, among which only can one study birds to advantage, he gathers around him the spoils of every land, arranges them into circles and groups which he imagines to be concentric, parallel, or diagonal, measures their bills and counts their feathers, and having thus performed his task, chuckles over it with the consciousness of his being a philosopher? Let him alone; you cannot kindle his heart with a spark of ethereal fire; but come along, and let us study Nature wherever we find her glories displayed. We cannot trace a bird without taking note of the plants and knolls and crags among which it lives; and if it digresses ever in its search for food, so must we digress in describing its actions." 


\section{The Observer of Habits.}

Like many of the naturalists 'of the old school, MacGillivray was strongly attracted to the study of habits and behaviour-and of the relations of the living creature to its environment-a study which, in new- fashioned terminology, is often called CEcology or Bionomics. He liked to study his plants in relation to their habitats, in their associations; he liked to study his birds as going concerns. It was organic life as it is lived in Nature - the business of living creatures - that appealed to him most strongly. This is very clearly seen in his History of British Birds, where so much attention is given to the haunts, the diet, the breeding, the seasonal changes of the species described. We notice also the continual attempt to correlate peculiarities of structure - particularly in the alimentary system-with peculiarities in habits and surroundings.

MacGillivray occupies an interesting position in the history of the science - representing the transition between what we may call the Linnæan and the Cuvierian levels of scientific description and interpretation. ${ }^{1}$ By the Linnæan level we mean the precise description of the intact creature, the corresponding description of its habits as a whole, and the correlation of the two. By the

${ }^{1}$ An interpretation of the history of Biology (since the time of Buffon) as a gradually deepening analysis is given in Prof. Patrick Geddes's remarkable "Synthetic Outline of the History of Biology," Proc. Roy. Phys. Soc. Edinburgh, 1885-6, pp. 905-911. 
Cuvierian level we mean the analysis of the body into its chief parts and organs, the corresponding study of the uses of the chief parts, the functions of the organs, and the correlation of the two. MacGilliviay's work seems to us to represent very precisely the transition from the Linnæan description of externals to the deeper Cuvierian description of the internal economy of the organism. Since his day, as is well known, the analysis of structure and of function has been pushed more and more deeply-from organs to tissues, from tissues to cells, and from cells to the living matter itself.

From the old-fashioned study of habits there has been until within recent years some measure of recoil, partly because of the fascinations of other lines of inquiry, but partly because it did not in its methods keep pace with the deepening analysis of structure and function. And here we see one of the interesting features of MacGillivray's work, that he felt the necessity of deepening the study of habits by bringing it into correlation with the results of anatomy and physiology.

Generalising the twofold lesson which is so forcibly suggested by MacGillivray's British Birds, we may say, in the first place, that natural history (in the narrower sense of œcology or bionomics) cannot be either stable or progressive, if it stand aloof from the results of the anatomical and physiological disciplines; and, in the second place, that these disciplines are saved from losing perspective and interest by being kept in touch with 
life as it is lived in Nature. Amid the undoubted and surely legitimate fascinations of dissection and osteology, of section-cutting and histology, of physiological chemistry and physiological physics, of embryology and fossil-hunting, and the like, do we not need to be reminded sometimes of what MacGillivray felt so strongly, that the chief end of our study is a better understanding of living creatures in their natural surroundings? In what we may perhaps call the keenly analytic atmosphere of modern zoology, there is no risk that any one will fail to appreciate the value of the abstractions which we make when we study the dead beast on the dissecting tray, or sections of parts of it under the microscope, or solutions of parts of it in the test-tube-but is there not a risk lest we forget that the picture and the problem with which the naturalist starts, and to which he must eventually return, is the picture and the problem of the shore-pool, the wayside pond, the open sea, the moorland tarn, the birdberg-in short, wild Nature and its drama of life?

To give a single instance of MacGillivray's vivid and careful pourtrayal of an episode in the business of life, we may quote his description of the pursuit of a lark by a hawk:-

"When about a mile beyond the Loch of Achlossan, I had my attention attracted by the cries of a lark, which I saw pursued by a hawk. It strove incessantly to keep above its enemy, which equally endeavoured to gain the ascendency, and 
sometimes succeeded. Numerous were the attempts the hawk made to seize the little bird, which, with wonderful agility, always evaded it by turning aside and shooting abruptly upwards. A single false movement would have been fatal. The hawk, unable to turn so quickly as the lark, endeavoured to seize it from one side, then from the other, sometimes from beneath, and now and then from above. Whenever it attempted to ascend, the lark strove to outdo it, and frequently succeeded. It seemed as if the lark could not venture to shoot off, for it always kept close to the hawk. The chase continued for about fifteen minutes, attempts at seizure being made at very short intervals all that time. Sometimes the hawk, shooting down obliquely, the lark, however; evading it, could not overcome the impetus given in time to have another clutch, but wheeled off to some distance. At length the lark appeared almost exhausted, and seemed drawing near the end of its career. Unable to rise above its enemy, and coming nearer and nearer to the ground, it tried a rapid descent, but was instantly overtaken, and repeatedly pounced at. The birds were now for a while quite close to each other, and several very quick movements were made by the hawk, and dexterously avoided by the lark. They were gradually descending, when the lark suddenly sped away towards a farm-steading about five hundred yards distant. The hawk pursued, and both passed so near to me, as I leaned against a wall, that the greyish-blue tint of the dorsal plumage, and the black moustaches of the pursuer were distinctly visible. Rapidly shooting in between the, corn-stacks, the lark was as rapidly followed. In a little while both birds re-appeared, flew round the house, and amongst the trees in the garden, then again shot in between the stacks, darted back among the trees, rose high 


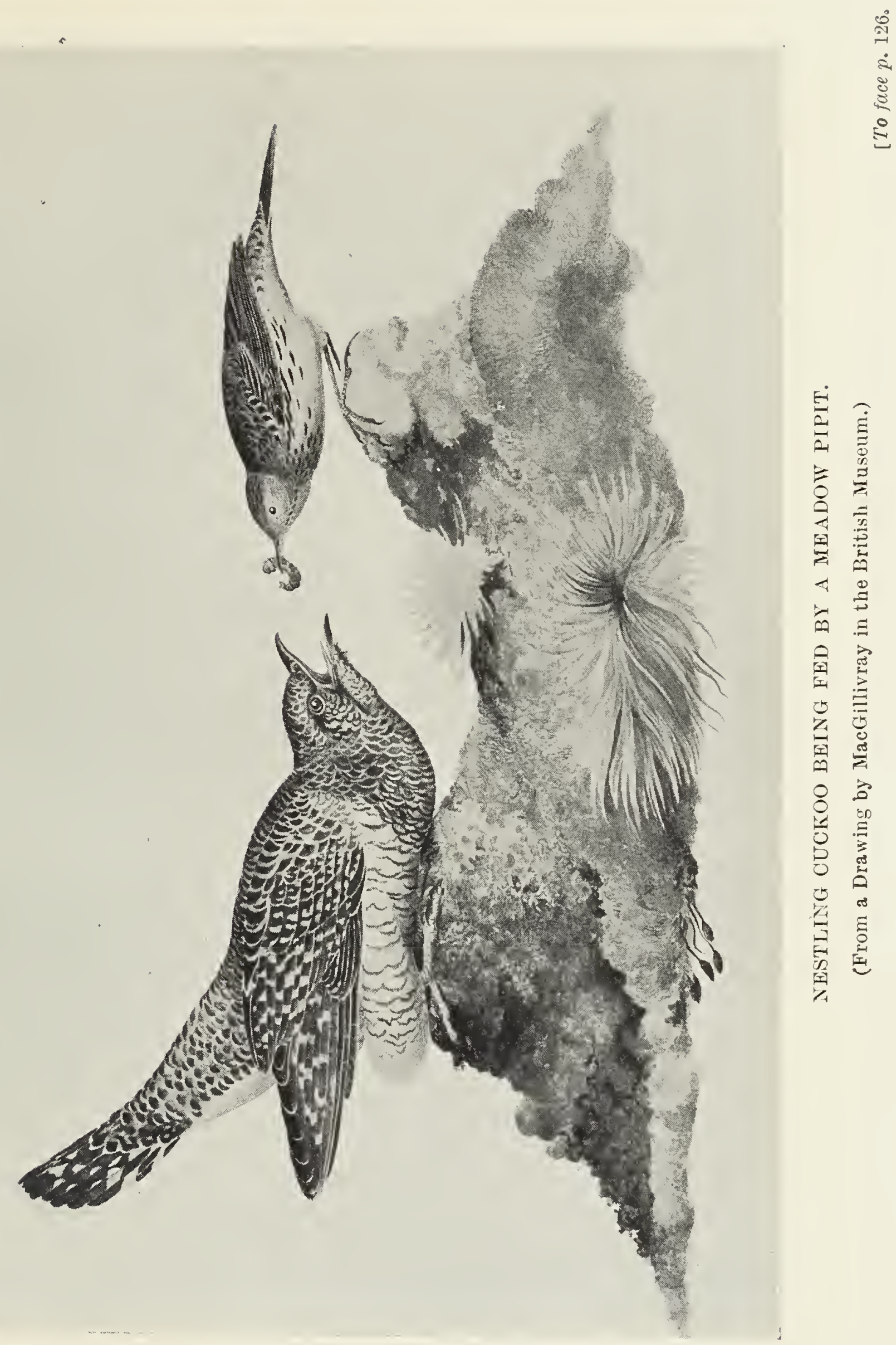



above them, and then sped away to this side and that, the lark all the while emitting at short interval's a low chirp, the hawk silent. At length, the lark suddenly dropped down among the trees and into the bushes, but so did the hawk. It was all over, I thought; but no-when the hawk re-appeared, he had nothing in his talons. He flew slowly along one side of the garden wall, then along the other, shot in among the trees, then among the stacks, flew round the house, searched the trees once more; but not finding what he looked for, flew off to a small tree by the road, and alighted on it.

"I have seen a more protracted chase, but none so interesting. It was evident that the lark could turn more abruptly than the hawk, and had equal speed in a direct flight. Probably, however, it had not equal endurance, and it seemed to know that if its enemy could come down upon it, all would be lost. In an open space, at least over water, the hawk must at length have secured it. The shelter of trees or bushes would not have availed the lark, had its pursuer been a sparrowhawk, which, however, could not have turned so quickly in the air. It seems surprising, after all, that there should be so little difference in the speed of two birds, one intended to capture and feed upon the other" (Natural History of Deeside, p. 299).

\section{A Lover of the Details of Life.}

When we say that MacGillivray was a type of the true naturalist, we mean that he had a synthetic outlook - on Nature, rather than on Birds and Beasts, or on Plants, or on the Earth; we mean also that he studied the life that is lived in the open, though of a truth he could wield the scalpel in the laboratory with the best; we mean 
that he cared much about the business of living creatures, their habits and instincts, their ways and means, their struggle for existence, their endeavour after well-being; but we mean something morethat he had the hardly-to-be-defined quality of almost affectionate regard for things in themselves, (not apparently, but perhaps really in the Ding-ansich sense), that he enjoyed a fine stone, that he handled his shells tenderly, that he had an acquaintance with many birds as personalities-that he had, what Meredith calls "a love-exceeding a simple love-of things that move in rushes and rubble of woody wreck."

One of the marks of a naturalist of this species - to which Huxley, with all his magnificent genius, confessed that he did not belong-is a delight in details, which so often reveal the personal equation of the organism. To detect this, and the part it plays in the plot, is no small part of the perennial charm of natural history.

It was this mood that led MacGillivray to notice that the squirrel peeled its beech-nuts after unshelling them; to time the duration of the lark's song in varying conditions; to count the 2379 feathers in the nest of the long-tailed tit; to watch the water-shrew sporting on the surface of the water, rapidly shooting along in curves, yet scarcely causing a ripple; to chronicle every movement of the long-eared bat as it prepares to go to sleep; to measure the great ant-hills, seven feet by five, in the pine woods at Invercauld; to sort out 
the 600 odd ants and flies and beetles in the green woodpecker's stomach; to peer into a thousand and one little details of this sort, which make his studies of Birds and of Mammals so realistic and interesting. He was, indeed, far removed from the impressionist type of natural history.

\section{"The Accurate MacGillivray."}

Emotional Celt that he was, MacGillivray had a highly developed sense of precision, and welldeserved Darwin's epithet with which we have headed this paragraph. What was characteristic of his inherited mental framework was doubtless developed by not having many books or teachers to lean on, when he was training himself, and by his prolonged discipline in dissection, drawing, and museum-work. Even the neat labelling was symptomatic of "the accurate MacGillivray."

Professor James W. H. Trail, in referring to the work he did many years ago in the Natural History Museum of Aberdeen University, writes as follows :-

"During my work I had occasion to become well acquainted with Professor MacGillivray's collections preserved in the Museum. The neatness of his writing and methods were conspicuous in all his work; but admiration of this was soon followed by respect and honour as I came to know more fully the width and accuracy of his work. From his collections I turned to his writings, to find only still stronger reason for wonder that he could have found opportunity to write so much, and on so 
widely different sides of natural science. But still higher rose my respect for his talents as I realised that he was no mere compiler, but that all he wrote showed that he had learned in practical study what he sought to teach."

His independence may be illustrated by a concrete case. It is well known that the stoat (Mustela erminea), which is brownish-red in summer, usually becomes white in winter, all but the black tip of the tail, and is known as the ermine. The prevalent view in MacGillivray's day was that the brownish-red hairs lost their pigment and became white, a theory backed by the authority of Bell. But when MacGillivray, after his wont, looked into the matter for himself, he found the accepted account unsatisfactory :-

"In an individual obtained in December 1834, the colour was a mixture of white and brownish-red. The hairs of the latter colour were not in the least degree faded, and those of the former were much shorter, and evidently just shooting; so that the change from brown to white would seem to take place by the substitution of new white hairs for those of the summer dress."

This view has been confirmed by the very careful investigations of Professor Schwalbe. Several instances of stoats of a brown colour patched with white, in which the white hairs were of the same length as the brown, led MacGillivray to think that "sometimes the brown hairs themselves, on the application of intense cold, become whitened "; and it is interesting again to notice that 
there is modern corroboration of this exceptional occurrence. In the case of the mountain hare, where, according to MacGillivray, the white winter hairs are due to fresh growth, the investigation of von Loewis leads to the conclusion that brown hairs may sometimes be changed in situ into white ones. But the merits of the particular case do not here greatly concern us, our point being merely to illustrate MacGillivray's independence and carefulness.

\section{The Ornithologist.}

In the history of British ornithology a very high place must be given to MacGillivray for three reasons-(1) because of his classification, which got below the often misleading resemblances in superficial appearance and habits to the affinities indicated by anatomical architecture; (2) because of the pattern of thoroughness which he set in his anatomical investigations; and (3) because of the excellence of his observations on the life and habits of birds. We have already referred to two of these merits, but let us explain the importance of the first.

Without going far into the discussion of a difficult and technical subject, we can perhaps best explain the importance of MacGillivray's work in classification by noticing that the arrangements in vogue among British ornithologists about 1837, when the first volume of the History of British Birds appeared, were based for the most part on the characters of the bill, the legs, the toes, the 
claws, and so forth. Some went so far as to take the tongue as their guide, but it proved, as the late Prof. Alfred Newton said, a very unruly member for the classifier! All these characters are of zoological interest, but they are superficial adaptations to similarities of habit, and are of no service in revealing the deep-seated structural affinities which a natural classification should reflect. Thus it is certain that swifts are not nearly related to swallows, nor owls to eagles and hawks.

Prof. Alfred Newton points out that in Sir Richard Owen's celebrated article "Aves," in Todd's Cyclopoedia of Anatomy and Physiology, which appeared the year before the first volume of MacGillivray's British Birds, the distinguished zoologist was content to adopt, as he tells us, a classification proposed by Kirby, which was practically that of Linnæus, improved by Cuvier, with an additional modification of Illiger's-" "all these three authors having totally ignored any but external characters."

What then did MacGillivray do? He insisted on getting below superficialities to the internal architecture, devoting particular attention to the alimentary system. This was a turning point in the history of British ornithology, and it may be of interest still to quote some of the terms of MacGillivray's thesis :-

"Some ingenious writers have attempted to show that a knowledge of the internal structure of animals is not essential to the zoologist, who, it is said, may get on remarkably well, and form the 
most natural arrangements, by attending merely to the exterior. The views of such persons are not likely to find much favour in the eyes of those who have studied animals as organised beings, and who do not remain satisfied with inspecting their surfaces. Zootomy regards the entire structure of animals, which must be examined in all their parts before the zoologist can arrange them according to their affinities. The study of their interior must in fact form the basis of all arrangement; and although many natural groups may be formed by attending exclusively to the exterior of animals, it is only because their internal organisation is presumed to be similar. The external parts afford an index to the internal; and if we find a bird having a short hooked bill and curved claws, we shall not be wrong in inferring that it has a wide œsophagus and a large membranous stomach. ..

"No rational system of ornithology has ever" appeared, for these two reasons: because no system-maker has been equally acquainted with the internal structure, the external parts, and the habits and actions of birds; and, more especially, because birds have not yet been subjected to a sufficiently minute examination. I have been induced to offer these remarks, because I regret that the science has been degraded by having been left entirely in the hands of those who appear to despise, because they have no knowledge of, the internal structure of birds; and I have considered it my duty to impress upon the student the necessity of dissecting with all diligence.

"Were it possible to cast away all the knowledge already acquired, and commence anew upon the plan of considering birds as admirable specimens of divine workmanship, to be excmined in all their details, we should, I believe, be great gainers in real knowledge." 
There is perhaps a suggestion of the "new broom" in this desire to sweep away the accumulations of the past and begin afresh, and it must be remembered that, while Britain lagged behind, there had been several steps of progress on the Continent towards a scientific system of birds. We may refer especially to the merits of the arrangement proposed by L'Herminier in 1827, of which MacGillivray was doubtless aware, since there is a notice of it in the Edinburgh Journal of Natural History $(1837$, p. 90) which he edited. The notice, which was probably by MacGillivray himself, ends with the paragraph :-

"By researches of this kind, that is by comparing the parts in different genera and families, it may be expected that much light will ultimately be thrown on the natural arrangement of birds, which at present is left in the hands of persons who can do little more than compare skins and stuffed specimens, and who, ludicrously, enough, perpetually talk of the 'strict analysis" by which they have absolutely fixed the order of Nature."

Surprise has often been expressed that MacGillivray, in spite of his insight into the sound method of classification, should have committed at a deeper level the mistake for which he blamed his predecessors; they trusted to external features and he to the alimentary tract - too narrow a basis for both. It is remarkable, moreover, that while he made important discoveries in regard to 
differences and resemblances in the vocal muscles, he left it to Johannes Müller to point out their taxonomic value. The explanation is doubtless perfectly simple, that all the energy MacGillivray could spare from professorial duties and Brodwissenschaft was occupied in the great task of completing his History of British Birds, of working out the actual descriptions-so incomparably well done. He never had time to return to the general problem of natural relationships.

Of MacGillivray's contribution to the classification of birds, the late Prof. Alfred Newton writes in the Introduction to his Dictionary of Birds (1896):-

"No one in Britain seems to have attempted to found any scientific arrangement of birds on other than external characters until, in 1837, William MacGillivray issued the first volume of his History of British Birds, wherein, though professing (p. 19) 'not to add a new system to the many already in partial use, or that have passed away like their authors,' he propounded (pp. 1618) a scheme for classifying the birds of Europe at least, founded on a 'consideration of the digestive organs, which merit special attention, on account, not so much of their great importance in the economy of birds, as the nervous, vascular and other systems are not behind them in this respect; but because, exhibiting great diversity of form and structure, in accordance with the nature of the food, they are more obviously qualified to afford a basis for the classification of the numerous species of birds' ( $p .52)$. Experience has again and again exposed the fallacy of 
this last conclusion, but it is no disparagement of its author to say, that in this passage, as well as in others that might be quoted, he was greater as anatomist than as a logician.

"He was indeed thoroughly grounded in anatomy, and though undoubtedly the digestive organs of birds have a claim to the fullest consideration, yet MacGillivray himself subsequently became aware of the fact that there were several other parts of their structure as important from the point of view of classification. $\mathrm{He}$ it was, apparently, who first detected the essential difference of the organs of voice presented by some of the New World Passeres (subsequently known as Clamatores); and the earliest intimation of this seems to be given in his anatomical description of the Arkansas Flycatcher, Tyrannus verticalis, which was published in 1838 (Ornithol. Biog. iv., p. $425)$, though it must be admitted that he did notbecause he then could not-perceive the bearing of their difference, which was reserved to be shown by the investigation of a still greater anatomist, and of one who had fuller facilities for research, and thereby almost revolutionised, as will presently be mentioned, the views of systematists as to this Order of Birds. : .

"His scheme of classification, being as before stated partial, need not be given in detail. Its great merit is that it proved the necessity of combining another and hitherto much-neglected factor in any natural arrangement, though vitiated, as so many other schemes have been, by being based wholly on one class of characters."

In an appreciation there is always a danger of overpraising the subject, and it is therefore satisfactory to be able to quote the verdict of the 
late Prof. Alfred Newton, who was not lavish in his compliments :-

"This is not the place to dwell on MacGillivray's merits; but I may perhaps be excused for repeating my opinion that, after Willughby, MacGillivray was the greatest and most original ornithological genius save one ${ }^{1}$ (who did not live long enough to make his powers widely known) that this island has produced." 2

\section{And again he says :-}

"Among ornithologists of the highest rank there have been few whose opinion is more worthy of attention than MacGillivray, a trained anatomist and a man of thoroughly independent mind." 3

\section{Independence and Carefulness of his Work.}

The qualities of independence and thoroughness which made MacGillivray so sure-footed as an ornithologist were characteristic of the man, and might be illustrated in reference to all his works. His book of 400 pages on the molluses of the north-east of Scotland was completed in less than two years, during which he had many other irons in the fire. But there is no careless work in it. He deals with 340 species, more than two-thirds of which were collected by himself. With one exception he admitted no species that he had not examined himself; and all the specific descriptions were original. He certainly made too many new

1 Probably H. N. Turner.

2 Dictionary of Birds, 1896, Introduction, p. 60. $\quad$ Ibid., p. 117. 
species (which the limited facilities at his command in the way of books and specimens for comparison may excuse), and perhaps a naturalist of his clearness and insight might have shaken off some of the inherited fallacies of classification, such as including spirally coiled Foraminifera among Cephalopods, yet so good was his workmanship that the book remains not only interesting but valuable. Let us again illustrate the wholesome humour of the $\operatorname{man}:-$

"I present it with confidence to the public; because I am conscious of having prepared it with great care, and because I think it will be useful. The specific descriptions I have made fuller than usual, because I am anxious to induce my pupils, not to content themselves merely with learning the names of objects, as I have observed to be the prevailing practice both here and elsewhere. It is, in fact, a matter of no importance to an individual, by what name an object is known to him, provided he be acquainted with its structure and relations; although a fixed nomenclature is essential to the general progress of knowledge. For this reason, I have not withheld the various species which have appeared to be new to science, although the want of access to all the works and essays published of late years, leaves it probable that some of them have been already named. It is but a pitiful manifestation of self-esteem to withhold the knowledge of an object, lest it should ultimately be found to have been already communicated in some work inaccessible to the student. Besides, if I have ignorantly given new names to objects already named, who of the most successful cultivators of zoology has not often committed similar errors?" 


\section{His Enthusiasm fór Natural History.}

MacGillivray had a strongly marked Celtic temperament. Very reserved, he was emphatically a man of feeling; full of enthusiasm for Nature, he expressed this in a quietly habitual outlook and activity, and only occasionally in outbursts of language. He did not suffer fools gladly, nor those who, being deaf and blind to Nature, despised his craft. Fundamentally scientific as he was, he had the "second sight," that sees the transcendental side of things. Those to whom this temperament is as a rune whose meaning has been lost, cannot understand that the sometimes extraordinary outbursts of enthusiasm were "spates" on a habitually gentle stream, and that the religious reflections, which sound a little strange to modern ears, were perfectly natural to the author and congruent with the happily serious mood of the age.

One simple fact should be borne in mind, that whereas the study of animated nature is now regarded as a worthy discipline of the developing human spirit, and even as a possibly useful branch of science-for that counts for much before the judgment seat of respectability-this was far from being the case in the first half of the nineteenth century. So when MacGillivray's enthusiasm leads to a fervour of language which seems sometimes a little overdone, we must remember what he 
says at the beginning of his Lives of Eminent Zoologists (1834) :-

"Only a few years ago, natural history was held in some degree of contempt by the enlightened as well as by the ignorant; its cultivators were considered as triflers, wasting their energies upon that which could profit nothing; and the information which it affords was looked upon as unworthy of the attention of persons fitted for intellectual pursuits."

In the preface to his History of the Molluscous Animals of Scotland (1843), he notes that it is the first zoological work emanating from the University of Aberdeen, and goes on to say :-

"I cannot but look upon it as indicating the not distant dawn of an era, destined, I trust, to produce investigations, the importance of which will tend to give our city a rank, certainly not yet acquired, among those distinguished for the cultivation of natural history, the most delightful of all sciences, the source of all knowledge, the study best adapted to refine our affections, and to bring us continually into the presence of our Creator, the maker and preserver of us, and all those wonderful objects that everywhere present themselves to our view. The time is almost gone when a little Latin, a little Greek, a little mathematics, a little natural philosophy, and a little moral philosophy, in such spare quantities as 'one small head could hold,' made an accomplished scholar. The book of Nature has been opened to us, and whatever profit there may be in storing our minds with phrases, it would require some ingenuity to show that the knowledge of things is not more useful than that of words. 
Some defend the system of wasting five or six years of a man's life in learning so much Latin as may barely suffice to enable him to read a page of a classical author without the aid of a Dictionary, on the ground of its being an exercise calculated to fix the attention and to exercise the memory; but a more useful and far nobler study is that of Nature, which calls into action every faculty of the mind, engages the best affections, and has reference to the perfect works of a perfect Creator. 'Ask now the beasts, and they shall teach thee; and the fowls of the air, and they shall tell thee; or speak to the earth, and it shall teach thee; and the fishes of the sea shall declare it unto thee. Who knoweth not in all these that the hand of the Lord hath wrought this?' Let Latin and Greek have their due share of attention, but let not the incubus of classic lore be permitted to smother the mind, that, if unrestrained, would inhale with delight the pure air of heaven."

This was written in 1843, and while it has a quaint, antique flavour - the young science encouraging itself under the ægis of religion-we read in its naïve frankness what we may find around us to-day, on the one hand the naturalist's constitutional difficulty in appreciating the significance of the humanities, and, on the other hand, the perennial hopefulness of the enthusiast that along his line of study will be found at last that liberal education which mankind has sought after for thousands of years.

\section{His Style.}

In estimating MacGillivray's share in the development of natural history in Britain, we must 
take account of the influence of his style in attracting students and amateurs to the science. He was notable for what was in those days rare-a combination of picturesqueness and accuracy. He had also a sense of perspective in presenting his studies to the laity-in their many degrees-so that his exposition was interesting without being falsely simple.

In regard to his style it must be admitted that it is at times exuberant, and at times very unconventional; but it is interesting to observe that he was fully conscious of this, and there was a deliberate method in his variations. Speaking of this in the preface to the second volume of his British Birds, he says :-

"In the present work, as in others, and in all my papers published in various journals, I have endeavoured to adapt the style to the subject, rendering it compact and precise when engaged with technical descriptions, copious and florid when treating of the actions and haunts of birds, abrupt or continuous, direct or discursive, harsh or harmonious, according to the varying circumstances of the case. My aim has been to amuse as well as to instruct, to engage the affections as well as to enlighten the understanding, to induce the traveller on the road to science to make occasional excursions tending to raise his spirits, and to show to the public that ornithology is not necessarily so repulsive as some of its votaries represent.

"Seated on the brow of this craggy cliff, with the glorious ocean and the boundless firmament spread out before and around him, who, that has a mind sensible to the beauties of creation, could look 
down upon the shelf that holds the fierce nestlings screaming over the bloody prey which their mother has just laid before them, and commence a description of the golden eagle in the 'plain didactic style' recommended by those whose frozen heart never thaws, whose tuneless throat emits grave and measured croaks, but can utter no song of joy and love and praise."

\section{Of the wealth of life he writes:-}

"From the gigantic elephant that roams among the splendid forests of the warmer regions of the earth, the unwieldy hippopotamus that plunges in the pools and marshes of the African wilds, and the timid and graceful giraffe that bounds over the sandy desert, down to the little dormouse that we find slumbering in its winter retreat, to the lemming that in congregated myriads overruns the fields of the North, or to the mole that burrows under our feet, we find an astonishing variety of beings, exhibiting forms, instincts, passions, and pursuits, which adapt them for the occupation of every part of the globe. The woods, the plains, the mountains, and the sands of the sea, are replete with life. The waters, too, whether of the ocean or of the land, teem with animated beings. Scarcely is a particle of matter to be found that does not present inhabitants to our view; and a drop of ditch-water is a little world in itself, stored with inmates of corresponding magnitude."

Of the fundamental mysteriousness of even the commonest things he writes :-

"In the construction of the familiar fly that buzzes through our apartments, not less than in the frame of the mighty elephant-in the simple blade

\footnotetext{
1 Lives of Eminent Zoologists, 1834, p. 28.
} 
of grass that springs from between the stones of the pavement, not less than in the knotted oak or the graceful palm-in the small cube of salt, not less than in the granitic mountain or the volcanic cone-there is something of a mysterious nature, the comprehension of which would be a much more glorious achievement than any that the human intellect has yet performed."

And again :-

"The world is full of wonders. . . . In every corner, as well as in every open place, you meet with something not understood."

On leaping a wall he came suddenly upon a fungus :-

"There it stood, not at all courting observation, on a tuft of green hypnum, beside a pine-trunkits broad pileus, six inches in diameter, glowing with tints nowhere else to be seen in Nature-carmine in the centre, shaded into orange-scarlet, the margin buff. Some pale warty scurf, the remains of the volva, still adhered to it, but did not mar its beauty. Its stalk, eight inches high, and nearly an inch thick, stood erect upon its bulb. From its upper part hung all round a delicate sheath, of a pale-yellow tint, so tender that you might blow it into shreds with a breath. Its beautiful yellowish-white lamellæ could be seen only after it was pulled. A snail had eaten a large hole into its stem. Was it formed to be devoured by mollusca? What are its uses? Why was it placed here? (Natural History of Deeside, p. 263.)

As an illustration of simple and unaffected, but very vivid description, we may take part of his sketch of the squirrel :-

1 Lives of Eminent Zoologists, p. 18. 
"It is amusing to watch it in its arboreal excursions, when you see it ascending the trunk and branches with surprising speed, running out even on slender twigs, always when in motion keeping its tail depressed, occasionally performing leaps from one branch to another, and when alarmed, scampering away at such a rate that you almost expect to see it miss its footing and fall down headlong. It feeds on nuts, beech-mast, acorns, buds, and the bark of young branches; generally, while eating, sitting on its haunches, with its tail elevated, holding the object between its paws, and dexterously unshelling the kernel, from which it even removes the outer pellicle before munching it. It does not reside entirely on trees, but frequently resorts to the ground, where it moves with nearly equal agility, leaping like a rabbit. The female produces three or four young ones about midsummer, which are deposited in a nest, formed of moss, fibrous roots, grass and leaves, curiously interwoven, and placed in a hole, or in the fork between two large branches.

"In autumn it lays up a store of provisions for winter, but usually in an irregular manner, depositing nuts in different places in the ground, and in holes of trees. When the cold weather commences, it becomes less active, and often dozes for days in its retreat; but it does not become completely torpid; and I have often seen it abroad in the midst of a most severe snowstorm. If the weather be comparatively mild, it exhibits its usual activity, feeding on bark and twigs."

That there is picturesque and accurate description here must be admitted on all hands, and the result of experiment leads us to confess that it is very difficult to shorten MacGillivray's sketch without losing something of value. 
Or take this description of the nest of the longtailed tit :-

"This nest is extremely beautiful, being of a very regular oval form, seven inches in length, and four inches and a quarter in the middle. It is composed of hypna, kept together by means of the flaxen fibres of plants, some wool, and delicate filmy shreds, interwoven chiefly in a transverse direction, and has nearly the whole of its outer surface stuck over with small grey lichens, which are not agglutinated, but kept attached by filaments. The aperture, which is round, is an inch and a quarter in diameter, and an inch and a half from the summit or dome. The outer shell thus formed, although well felted and interwoven, is only a quarter of an inch thick. Its inner surface is stuck over with large feathers, and the whole internal cavity is not merely lined but filled with the same materials. They are pretty closely compacted at the bottom and along the sides, and when shaken suffice to fill a hat of moderate phrenological pretensions, although not exactly mine, which belongs to what may be called a dunderhead. On being counted by a young man, the number is found to be 2379. They belong chiefly to the pheasant, wood pigeon, rook, and partridge; but there are also feathers of the breast of the missel thrush, of the yellow bunting, and of several other birds."

\section{As REGaRds Species.}

MacGillivray died seven years before the publication of The Origin of Species, and it is hardly surprising that there is little indication of the evolutionist outlook in his writings. In spite of the important work of the pioneers of evolution- 
theory-Buffon, Erasmus Darwin, Lamarck, Goethe, Treviranus, Etienne Geoffroy St Hilaire, and in spite of the many editions of the anonymous Vestiges of the Natural History of Creation (by Robert Chambers), we do not find that MacGillivray ever expressed himself on the new view of Nature which was beginning to dazzle men's eyes. There are passages, however, in which we can see this at least, that MacGillivray had moved away from the Linnæan dogma of the fixity of species. To one of the most explicit of these my attention has been directed by my colleague Prof. James W. H. Trail, and it is of sufficient interest to warrant full quotation. It is in MacGillivray's Manual of Botany, published in 1840. ${ }^{1}$

$\mathrm{He}$ adheres to the general view of his time in such a sentence as the following: "If we assume that a few individual plants, precisely similar in all respects, and differing in some respects from all others, were originally created, we should call these plants and their progeny, up to the present day, a species." But there is a symptom of a change of view in what follows. "From various causes, individuals that have been derived from these original individuals may differ considerably from them, and yet be of the same species. ... All species have a tendency to form varieties, insomuch, that no two individuals are ever precisely alike in all respects." We have not here any suggestion that one species has actually evolved from another,

${ }^{1}$ In the second edition, the passage is in Chapter XXVII., p. 229. 
but there is a distinct departure from the hard and fast idea of the fixity of species. Indeed he goes the length of saying, "We have no certain data from which we can infer the general permanence of specific forms."

After defining a species as "the aggregate of individuals agreeing in all their essential characters, breeding freely together, and producing perfect seed, which gives rise to similar individuals, also breeding together," he goes on to say: "There is nothing absolutely certain as to species, much less as to the groups into which they are disposed, as genera, families, orders, tribes, and the like. We merely agree to consider as species individual plants which closely resemble each other in the structure and form of their organs. Such species, however, often pass into each other by gradations, which render it impossible to draw a line of demarcation, and thus all species are more or less arbitrary. We know from observation, that all assumed species undergo changes from climate, cultivation, and other infuences; ${ }^{1}$ and individuals exhibiting remarkable alterations we call collectively varieties; but variety is a still more vague idea than species."

It is interesting to find that the subject of variations had a particular attraction for MacGillivray, and formed the theme of three articles in the Edinburgh Journal of Natural History (1837) which he edited. He there distinguishes minor 
individual differences from "extended degrees of aberration from regular specific characters," and he argues that the frequency of varieties is much greater among the simpler animals and plants. He cautiously admits: "It is also highly probable that these new forms of difference may sometimes be permanent, and transmit their peculiarities of structure or appearance to their progeny, with or without the aid of those circumstances which originally induced these varieties."

Is not a sentence like the last almost evolutionary? It sounds so for the moment, but MacGillivray never seems to have entertained the idea that one species could by variation give rise to another. "The boundaries of species," he says, "are absolutely fixed by Nature, one kind having no alliance with another."

In his brief review of the varieties occurring in animals and plants, MacGillivray expresses the conviction that "some intention or design, in regard to varieties, pervades Nature":-

"Unless we admit that some particular office, or function, is set apart for very many varieties we meet with, I do not see how we are to account for their differences being so great. I conceive that in many instances, not only are the amounts of difference assumed as varieties as great as those between species, but that their uses are as peculiarly important in the great scheme of the universe as those of a vast number of species belonging to the same class or tribe as the varieties. It is not pretended, however, that these uses can be defined, 
and it is but an inference to say varieties execute functions different from ordinary specimens."

One cannot help feeling that MacGillivray was on the line of finding a solution of his problem, but that he was kept back by his conviction that "Nature has been desirous of fixing the bounds" of species and varieties alike. He narrowly escaped making a great discovery.

It is very interesting to find, separated by a page of the Journal, a careful inquiry, with measurements, into the varieties of fox in Scotland, and, on the other hand, his frank confession of the mystery of variation, which is, indeed, part of the central mystery of life itself :-

"It is of course easy to refer all occurrences and all productions to the great source of beauty and variety in Nature; but it is the business of the naturalist to search for immediate causes, even though the search be likely to prove fruitless, and though we should be in danger of setting that down as a cause which is perfectly inadequate to the office, whilst the true cause remains hidden, and unadapted to human comprehension. If, however, no cause can be discerned or surmised, it is equally the business of the philosopher to ascribe the circumstance to the superintending agency of God; at least until further discoveries have been made, very many circumstances in connection with our subject must be disposed of in this way."

\section{A TEACHER.}

We cannot close this appreciation without referring to MacGillivray's influence as a teacher. Some of his students who rose to positions of 
distinction-such as Dr Matthews Duncan-have spoken with gratitude of what they owed to his lectures. It could hardly be otherwise, for he was keenly interested in his subject and believed in it as an educative discipline, and he had the gift of a picturesque style.

It is fitting to include here what was said by one of his students, the late Dr John F. Whitewho had much in common with MacGillivray-on the occasion of the presentation of a mural memorial tablet to Aberdeen University in 1900:-

"I must notice how easily he attracted to his special subjects even those students whose bias lay rather towards classics and mathematics. For it was a noticeable fact that many of his best prizemen were not students of science, but of other subjects. I do not know exactly whether it was owing to the magnetic influence of the earnest Professor, or whether it was that such students were attracted by the fresh study of Nature, hitherto to us a sealed book, but this I can say, that even the students of literature felt that here was no antagonism between the two pursuits, but rather that the one was complementary to the other. We felt that new powers were being awakened within us; that the hitherto dormant faculties of observation, comparison, classification, and generalisation were receiving a new stimulus. ... The influence of MacGillivray's methods and spirit abides indelible.

"MacGillivray's lectures were formal and precise, full of detail-perhaps overladen with detail. . . . But as he always illustrated by specimens, even these details were not felt burdensome. ... The Vestiges of Creation had appeared in the 
early forties, and clergymen attended MacGillivray's class in numbers to hear what science had to say in regard to the age and creation of the world. Professors came also; among others Professor Blackie, always eager for knowledge, enrolled himself as a student. In my own year, the late Principal Pirie, then Professor Pirie of the Theological Faculty in Marischal College, was a regular attender, and he gave a prize for a special examination in geology. But MacGillivray's activity did not end here. His Manual of the Mollusca of the North-Eastern Counties sent many classical and mathematical students twice or thrice weekly to the Fisher's Square, Footdee, to complete their collections and to search for the rare specimens to be found in the baskets of the deep-sea fishermen. When there was difficulty in identifying the specimen from the manual, it was taken to MacGillivray. It was at times like these that MacGillivray was seen at his best. Holding the specimen tenderly in his taper fingers, and applying to it a lens, he would descant on the difference or want of difference between a variety and a species. These were the half-hours in which Matthews Duncan, Thomas Keith, and Charles Murchison received their first lessons in science, long before they took to the study of medicine, in which they afterwards became famous. It was then that the Rev. Dr James Farquharson acquired early that knowledge which enabled him, when he had just taken his M.A. degree, to conduct for more than two years the classes of natural history and of botany during MacGillivray's last illness, and afterwards led him to take an active part in the work of the Berwickshire Naturalists' Club during his forty years' residence in Selkirk. It was under this sort of stimulus that Dr Thomas Jamieson of Ellon threw himself into the geo- 
logical studies which have since made him the recognised authority in Scotland in regard to the alluvial deposits. It was MacGillivray that led Andrew Leith Adams, son of the great Banchory scholar, to devote himself when a surgeon in the army to prolonged studies in natural history, studies which led to his retirement from the army to occupy a chair in Queen's College, Cork. In this class-room there sat for many years the late Dr Alex. Cruickshank, storing his mind with the secrets of the Nature he loved so well, the joy of his life. It is to these studies that the university and the city owe the munificent gift of our Botanic Garden, presented by Miss Cruickshank in memory of her brother. I could give the names of many schoolmasters, such as James Anderson of Foveran, men who carried their love of natural science into their several parishes, studying the works of Nature themselves, and inculcating her lessons on their pupils."

In connection with MacGillivray's teaching we may quote a paragraph from the preface to his book on molluscs-a remarkable preface, of which Prof. Trail well says - "It is so characteristic of the man's whole work, that it should be read for its value as a clue to his outlook on life and as a standard for all workers, whether in natural science or in other fields":-

"Having been recalled to my native place, in May 1841, I naturally felt a desire of renewing my acquaintance with the productions of a district often traversed by me while prosecuting my studies at the universities there, and not being aware of any very important investigations having been conducted in 
this much neglected, though not uninteresting, part of Scotland, with reference to its zoology, I thought it might be useful to describe some or all of its numerous animals. I therefore at once commenced an examination of the mammalia, birds, reptiles, fishes, mollusca, insects, and radiata, the results of which I intend, in due time, to lay before the public. Thinking, however, that the pupils whom I have to initiate in the science to which my labours have, for many years, been directed, could not acquire much practical acquaintance with most of these tribes of animals, in the winter season, when engaged with their various academical studies, I selected a branch of zoology, which I thought capable of affording them greater facilities for observation than any other."

In commenting on this preface, Prof. Trail remarks :-

"The promise thus given in the commencement of his tenure of duty in Aberdeen was well kept up during the eleven years that he held the Professorship. He taught zoology and geology in winter, and botany in summer; and into all he brought the same spirit of inquiry. There was no provision within the University, until many years after, for work in the laboratory; but MacGillivray delighted in excursions, to which he welcomed those who would come; and few teachers were more fitted to aid beginners in such studies. The materials collected in his excursions were employed in the formation of a museum to illustrate the courses of study." 1

MacGillivray was the originator of a Natural

1 "Natural Science in the Aberdeen Universities," Aberdeen Quatercentenary Studies, p. 170. 
History Society in Aberdeen, to which he communicated a series of papers on the Natural History of Deeside; and in the lineal descendants of this old Society the MacGillivray tradition is still happily sustained, as it also was very effectively in the admirable work of the late Mr George Sim, author of The Vertebrate Frana of Dee. MacGillivray's herbarium is carefully preserved in Aberdeen University by Prof. Trail, and some of his natural history specimens are still in the University Museum, though many have gone the way of all things brittle and stuffed. Some of the latter, it is interesting to notice, have been replaced by the pious hands of the great ornithologist's nephew, $\mathrm{Mr}$ W. L. MacGillivray, of Eoligary in Barra. A MacGillivray Prize in Natural History, instituted recently by Mrs Beaton, the Professor's daughter, was gained for the first time in 1909 by a student who sent in a fine collection illustrative of the external characters of birds. In these, and in many other ways, we hope, the influence of one who worked strenuously and thoroughly remains. It is interesting even to inquire whether Charles Darwin himself was not influenced by the long Natural History talks he used to have when an impressionable student in Edinburgh with the quiet, but wonderfully attractive, hard-working Conservator of the College of Surgeons' Museum-so full of first-hand knowledge - "the accurate MacGillivray." 


\section{NATURE'S SOLACE.}

Like many naturalists before him and after him, MacGillivray had a touch of Nature-Mysticism. The strings of his nature were so tuned that they responded readily to certain aspects of Nature, and found some satisfaction in the response. This is a deep and difficult question, but we may remind ourselves that Man was cradled and brought up in Nature, and that it is therefore a probable condition of emotional sanity that he should periodically return to the old home, as the migratory birds do. It is this that gives deep import to that "uprush of feeling from below the ordinary level of consciousness," which we experience when we allow the beauty and meaning of Nature to work upon us.

It is probable, then, that we do not misunderstand MacGillivray when we say that, apart from the theodicy which Nature always was to him, he found in certain of its aspects a mystical solace. Remembering his sensitive and plastic Celtic temperament, let us take in illustration of his outlook the remarkable passage that follows ${ }^{1}$ one of the most self-revealing in all his writings :-

"One accustomed to the scenery and habits of

1 I owe my knowledge of the passage to my friend Dr Rudolf Galloway, Aberdeen, who has been loyal to the MacGillivray tradition in his devotion to birds and the breeding of them. It is from an article in the Northern Farmer, vol. i., p. 41, August 1844, entitled"On the Maritime Pastures of the Western and Eastern Coasts of Scotland." 
the eastern parts of Scotland would probably find no pleasure in these half-desert places, where not a whin-bush is to be seen, nor a rook or a rabbit to be met with. But to me the wild shores of the remote Hebrides have a peculiar charm. There, in the north, extends the crowded range of the Harris mountains, partially shrouded in vapours; on the other side are seen the hills of South Uist, among which Hecla stands pre-eminent; behind you are broken crags, patches of heath, pools of brown water, edged with sedges and horsetails, and covered with water-lilies; on either hand are long ranges of alternating cliffs and sands; and before you is spread out the great ocean, glowing with the reflected blaze of the setting sun. Strings of gannets are passing westward in the direction of St Kilda, forty miles distant, where they will arrive in less than half an hour; the sand fords resound with the creaking cries of the terns, which are seen hovering over a shoal of fry; the shrill cries of the oyster-catcher, and the loud screams of the curlew come from the distant corran; the thickets of the yellow iris around give out the singular notes of the corn-crake; and at intervals come the swellings of the ocean-murmur wafted by the gentle breezes from the rocky shore of the bleak headlands, where the grey eagle has perched his huge erie.

"The cattle are in the fold, the labourer at his evening meal, dimness is creeping westward over the sky, all Nature is in harmony with itself; there are no jarrings or discords; a holy calm steals over the mind, there is peace with the world, or rather the world is forgot and forgiven; injuries received rankle not in the breast; no envy is felt; the presence of the Eternal is around, it encloses you; you cannot, if you would, escape from it; and there when the broad disk of the great luminary 
has sunk behind the ocean's verge, on which project the dark masses of the St Kilda Isles, you are left in peace, to the communings of your own spirit, which, if in such circumstances it can harbour an unholy thought, must be desperately depraved. Who, in such a case, could wish to be back to society, to encounter the discords of an evil world, whose very zeal for the holiest of causes exhibits itself in animosities, hatreds, envies, jealousies, wranglings and strifes; when your most simple word or act is misrepresented, your beneficence repaid by ingratitude and calumny, your feelings heedlessly or gratuitously lacerated; your whole life spent in a perpetual struggle with the evils that assail you from without and from within.

"No, let me live here in peace, and die in hope, and let the green turf, in which the shamrock and the centaury rear their simple forms, cover the dust of one who is weary of the world, and like the captive falcon, would spread his pinions to the breeze, and joyously hasten to the rock of refuge.

"But other thoughts succeed, and the mind resumes its wonted tone. Another country, inhabited by a more enlightened and industrious race, has attractions of a different kind. There the natural pastures are of less importance, because the united labour and science of a civilised people have converted the barren moors into fertile fields, rendering of little trust the precarious supply of Nature's bounties, on which the Hebrideans chiefly live. Leaving these lonely shores of the west, I therefore hasten eastwards, where kind friends and intelligent pupils invite me to an excursion along the links of Belhelvie." 


\section{CHAPTER VII}

EXTRACTS FROM PROFESSOR MACGILLIVRAY'S WORKS, DESCRIPTIVE OF BIRD LIFE, OF PERSONAL ADVENTURE FOR SCIENTIFIC INVESTIGATION, OF PICTURESQUE SCENES, ETC.

\section{1.-The MerLin}

ON the side of the Lammer-Law, the highest hill of the low range that extends from the County of Peebles towards St Abb's Head, near the brink of a scar which has been worn deep in the gravelly soil by the undermining action of a rill, is a nest of the merlin, if nest that can be called which is merely a little flat space, strewn with a few sticks and withered sedges. You hear the hungry plaint of the young as the morning dawn rouses them from their slumbers. See! the mother advances a few steps, stretches her wings, shakes herself, inspects her plumage, trims a bent feather in her tail, picks a little clot of peat from her toe, eyes the heavens slantingly, and, throwing herself forward, spreads out her beautiful pinions and, launching into the air, ascends a few yards by strong flappings. How lightly she wheels on her circling flight, as she 
seems now to glance toward her young a look of maternal affection, and again surveys the distant plains! Now, her few short wheelings ended, off she shoots, flying in a direct line towards the Gifford Woods, where no doubt she expects to find a missel thrush by the edge of the orchard, a young partridge beneath the hedge, a lark carolling over the field, or at all events some object worthy of her pursuit. As you watch her motions, the male, having shaken off his drowsiness, trimmed his plumes, and scratched his cheek-he could do no more, for he has none of those combs in his claws with which the philosophers tell us some birds are furnished for the purpose of combing their whiskers - springs into the air and, almost touching the tops of the broom and heather, the inhabitants of which might conceive him to be a harpy, speeds directly over the shoulder of the hill to search the upland moors. They are gone, and what remains? Look around you.

In the crimsoned east stretches out the smooth expanse of the German Ocean, bounded to the northward by the coast of Fife, toward the south by the shores of East Lothian. Straight before me, like a giant leaning on his elbow, or a volcano that in a single night has emerged from the deep, rises the rocky protuberance of the Bass, the haunt of thousands of gannets which, at this distance, however, I can perceive only with the aid of fancy. Beyond this, to the left of the dim Isle of May, with its glimmering light surmounting a range of whitened 
cliffs, and indicating to the mariner in the darkness of night and amid the howl of the tempest the path which will lead him to his desired haven. Along the eastern horizon stretches a dim ridge of undulated ground, the culminating points of which, as the French geologists say, are the broad eminence of Largo Law, the two Lomonds, and, lastly, the Ochil Hills, far in the north-west and shrouded in the undispersed haze of night. Nearer, but yet distant, is the beautiful mountain called Arthur Seat, behind which is the metropolis of Auld Scotland. There, though you cannot see her, sits Edina, like a queen on her throne of hills. As yet, none are astir on the quiet streets of the fair city save the drowsy watchman who, methinks (or, more correctly, I think), I hear at this moment proclaiming to the tall houses of the High Street or the arches of George the Fourth's Bridge that it is half-past three.

But look this way. A merlin has already arrived, bearing in its claws an unfortunate snipe which he clutched as it was searching for a few worms to satisfy the hunger of its patient uncomplaining young, that lay squat among the moss in the low grounds beside the Milton Burn. What a clamour the ravenous creatures make as their mother throws down the prey, which one of them presently seizes and appropriates to himself. Now she is off. But what is that on the hill top? A hawk, I guess, with a burden as large as itself. It comes, and that not slowly. It has arrived. A 
golden plover, with its beautiful black breast margined with white stood on the top of a mossy mound that overlooked a bog covered with the "snowy canna of the hill," of my great-grandfather, old Ossian, the Eriophorum angustifolium of my brethren in arms, the modern botanists, these "sons of little men," or men of great souls, as you please; when suddenly there came upon him the ruthless plunderer. Loud screamed the bird of the moors, as he sprung on wing and sped his rapid flight. It was a beautiful sight to be seen. Like a pirate chasing a merchantman among the shoals of Cuba, did the merlin thread the mazes of the plover's path, 'until at length, coming down upon him at an unlucky turn, he drove him to the ground, stunned and gasping, his right pulmonary vein ruptured (as you might have guessed had you seen the bright blood that issued from his mouth, for had it been the artery, as you well know, the blood would have been dark). There the ruthless marauder squeezed and pushed him with his talons like a burker of true breed, and scalped him as a Red man of "the Ohio woods" used to scalp the pioneers fifty years ago, and screamed over him like a smocked Cossack over a murdered Frenchman in the Hundred Days.

Let him divide the prey; for see how gorgeous the crimson of the canopy that hangs over the eastern waters! The plains of Lothian stretch towards the sea, covered with woods and corn, farmhouses and villages. There rises the beautiful 
cone of Berwick Law, here the rounded eminence of Traprain; beyond Haddington the undulated ridge of the Garlton Hills. All these, with the isles and the mountains before observed, you perceive are igneous or trap rocks, while the plains through which they protrude belong to the "coal formation," or to some formation the precise station of which seems to puzzle those ingenious people, the geologists, who are perpetually building worlds and pulling them to pieces. The blaze of the eastern sky becomes more intense. Anon a flood of light streams from the edge of the ocean and now, emerging from the deep, slowly and steadily, mounts the great orb of day, until at length it clears the horizon and rolls upwards into the heavens, a glory in the full splendour of which your eyes are no more fitted to gaze than your intellect to contemplate the perfection of its Maker. Now just recollect all the beauties of the ancient mythology; fancy to yourself Apollo rising from the lap of Thetis, or "Dan Sol" with his golden wheeled chariot and fiery steeds, and think for a moment what a contemptible figure they make compared with that sun which now advances "rejoicing like a strong man to run a race," that ocean which blazes with light, and that sky suffused with all glorious tints, from the intense brightness of its eastern region to the crimson of the light clouds that hover over the Firth and the purple blue of the western hills. Joy spreads over Nature. The lark carols in the sky, the mavis pours forth 
his mellow song from the hill, the plover whistles shrill on the moor, the plaint of the lapwing comes from the bog beneath, and hear! Was it thunder? No - hear! From far overhead comes the drumming sound of the snipe, which you may see wheeling and diving in the upper regions of the air. The "lang yellow broom" on "the ferny brae," the white flowered parnassia in the mossy swamp, the golden hieracium on that greywacke crag, and the long clusters of the purple foxglove scattered along the sides of the "scar," all seem to burst in beauty on your sight. It is a lovely world after all. Let them talk of their myrtle groves of the "sweet south," their pine forests of "the stormy north," their tangled jungles of "the gorgeous east," their primeval woods of "the far west," their palmy isles, their green savannahs, their steaming swamps, their burning desertsplace me among the purple heather of one of the Lammermoor hills, with a merlin's nest in view, and I leave them to enjoy their own pleasures. If they please they may ride crocodiles and thrapple rattle-snakes, for aught I care.

Again one of the falcons has arrived, with a lark in his claws. Come let us go for we have much to do before we reach Gifford where we are to breakfast. Nay, not so fast, "wait a wee"; we are on the Lammer Law, beside a hawk's nest, and I wish to shoot that smart little fellow that you see hastening away to Danskin Loch. In five minutes he will be there, for eight miles to a 
merlin are nothing. There I think $I$ see him as he goes dashing over the woods. The still pool, overgrown in parts with rushes and reeds, and shadowed by thick firs, brightening under the morning beams that shoot slantingly over the hollow in which it lies. The water hen moves merrily along, jerking up its white patched tail, as it leads its sooty brood to the sedgy thicket, the mallards are muddling and spluttering by the edge of the swamp, and a single heron stands on a little rocky isle, on a single leg, with indrawn neck and yellow bill directed forwards. Is there nothing else? Yes, the merlin skims over the pool; a sandpiper flies off and is pursued; the gallinules scramble among the reeds, the ducks splash in the water, and the heron lets down his leg and places himself in an attitude of observation. But the chase is over; the merlin flies off with his prey. Had I the "telescopic eye" of a kite I might see him advancing over the Cairn Hill. Here he comes; we can now see him without glasses. You may imagine, good reader, that you hear a shot, that the merlin comes to the ground, that thereupon the curtain falls, the "whaups" on the hill scream, and the company disperses. 


\section{2.-Mountain Inspiration.}

It is delightful to wander far away from the haunts and even the solitary huts of men, and, ascending the steep mountain, seat one's self on the ruinous cairn that crowns its summit, where, amid the grey stones, the ptarmigan gleans its Alpine food. There, communing with his own heart, in the wilderness, the lover of Nature cannot fail to look up to Nature's God. I believe it in fact impossible, in such a situation, on the height of Ben-na-muic-dhui or Ben Nevis, for example, not to be sensible, not merely of the existence but also of the presence of a Divinity. In that sacred temple, of which the everlasting hills are the pillars, and the blue vault of heaven the dome, he must be a fiend indeed who could harbour an unholy thought. But, to know himself, one must go there alone. Accompanied by his fellows, he may see all of external Nature that he could see in solitude, but the hidden things of his own heart will not be brought to light. To me the ascent of a lofty mountain has always induced a frame of mind similar to that inspired by entering a temple; and I cannot but look upon it as a gross profanation to enact in the midst of the sublimities of creation a convivial scene, such as is usually got up by parties from our large towns, who seem to have no higher 
aim in climbing to the top of Ben Lomond or Ben Ledi than to feast there upon cold chicken and "mountain dew," and toss as many stones as they can find over the precipices.-British Birds, vol. i., p. 204.

\section{3.-Flight of Birds.}

The folly of chasing sparrows depends upon the object you have in view. If the divine wisdom and power have been exercised in creating them, and the good providence of God displayed in caring for them, it cannot be foolish in us to study their habits, provided we look upon them with relation to the author of their being. However, let us go on: they have flown, and you see that they move about in flocks, that is, are gregarious at this season, as many species of small birds are in winter-the lark, for example, linnets, and buntings. Before us are some birds in the hedge, chaffinches, which, as you observe, fly in a manner somewhat different from that of the sparrows. Then, the rooks, which you see high in the air, moving steadily and sedately along, with regularly-timed beats of their expanded wings, and now, as if seized with some sudden panic, or impelled by some frolicsome propensity, dashing down headlong, crossing each other, whirling and undulating: how different is their flight from that of those wood pigeons, which 
advance with rapidity, moving their wings with quick strokes, and making the air whistle as they glide along; while the two white gulls, with their outstretched, long, arched wings, float buoyantly in the clear sky, bending gently to either side, as they advance from the sea.-British Birds, vol. i., p. 238.

\section{4.-A Lover of Nature-Audubon.}

We are all school-boys, or at least scholars, and when we forget that we are so, we become fools. If we go to the school of Nature, and study God's providence, we can be better employed only when in the school of revelation we study God's grace. Let us ever retain our school-boy feelings, so long as they are innocent. There is a freshness of heart manifest in every real lover of Nature-a delightful feeling, gratifying not to one's self only, but to his companions. When it is gone, and the frost of worldly wisdom has chilled the affections, the naturalist becomes a pompous, pedantic, stiffnecked, cold-blooded thing, from which you shrink back unwittingly. I have the pleasure of being familiar with an ornithologist who has spent thirty years in study, who has ransacked the steaming swamps of Louisiana, traversed the tangled and trackless woods of the Missouri, ascended the flowery heights of the Alleghanies, and clambered 


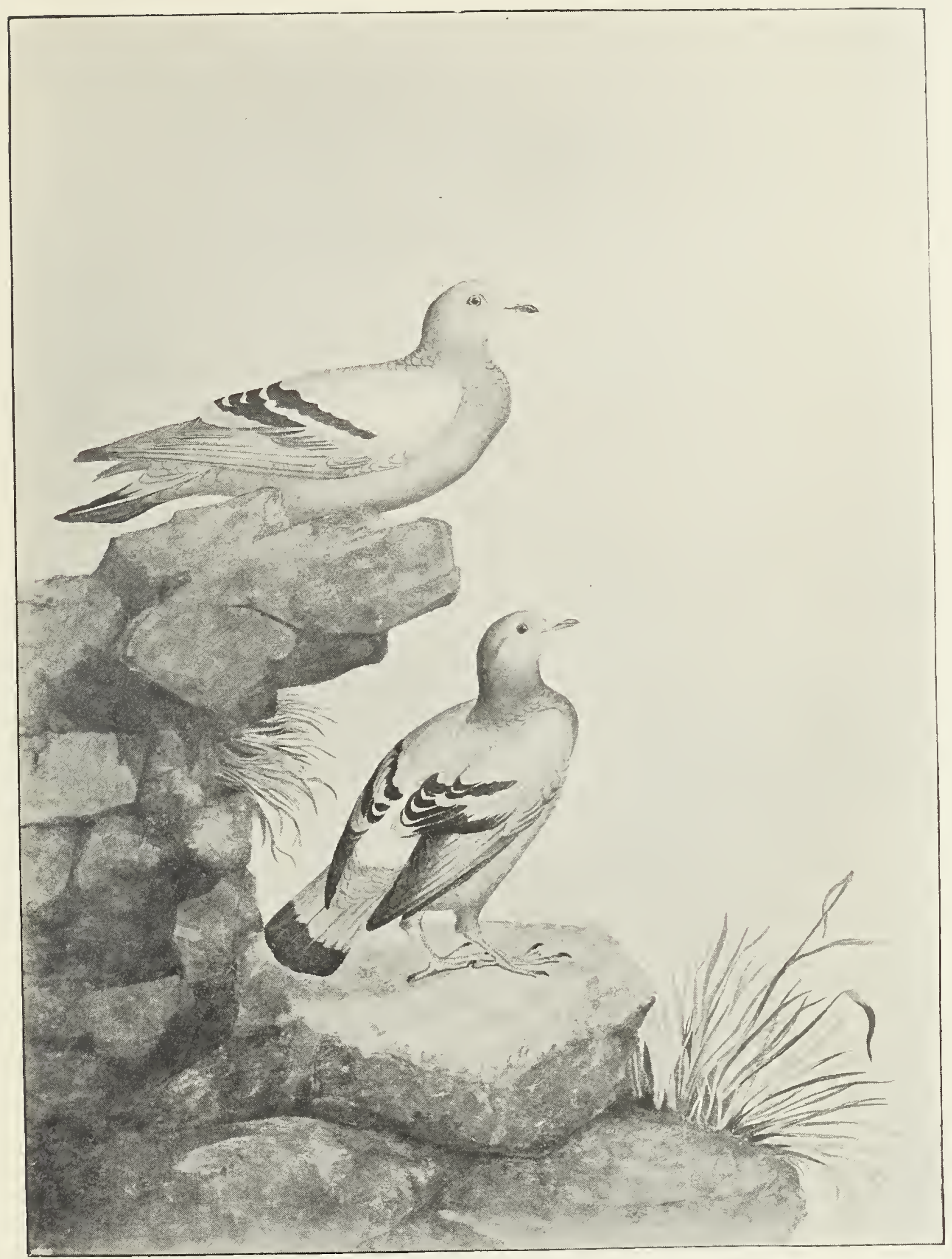

THE ROCK DOVE, ADULT FEMALE AND YOUNG.

(From a Drawing by MacGillivray in the British Museum.) 


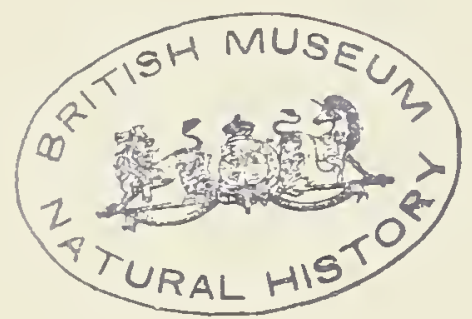


among the desolate crags of cold and misty Labrador; who has observed, and shot and drawn, and described the birds of half a continent. Well, what then? Has this man the grave and solemn croak of that carrion-crow, or the pertness and impudence of that pilfering jackdaw. No, I have seen him chasing tom-tits with all the glee of a truant school-boy, and have heard him communicate his knowledge with the fervour and feeling of a warm-hearted soul, as he is._British Birds, vol. i., p. 239.

\section{5.-A Tame Young Rock Dove.}

The boys in the Outer Hebrides often attempt to rear young doves, but their cares are seldom continued long enough. They introduce the food, dry barley grain, by the side of the mouth, which occasions inflammation and swelling of the basal margins of the mandibles. When a boy, I had a young rock dove, which I fed for some time in this manner, until the bill became tumid and sore, when, in consequence of advice from a friend, I took a mouthful of barley and water, and introduced the pigeon's bill, when the bird soon satisfied itself, flapping its wings gently and uttering a low cry all the while. It grew up vigorously, shed the yellow down-tips of its feathers, and began to fly about. Towards the middle of autumn it renewed 
its plumage, and assumed the bright and beautiful tints of the adult male. Whenever I escaped from the detested pages of Virgil and Horace, the pigeon was sure to fly to me, and sometimes alighted on my head or shoulder, directing its bill towards my mouth, and flapping its wings. Nor did it ever fly off with the wild pigeons, which almost every day fed near the house, although it had no companions of its own species. At length some fatal whim induced it to make an excursion to a village about a mile distant, when it alighted on the roof of a hut, and the boys pelted it dead with stones. Long and true was my sorrow for my lost companion; the remembrance of it will probably continue as long as life. I have since mourned the loss of a far dearer dove. They were gentle and lovely beings; but while the one has been blended with the elements, the other remains "hid with Christ in God," and for it I "mourn not as those who have no hope."-British Birds, vol. i., pp. 275, 276.

6.-A Winter Bird Scene at the Mouth of the Almond.

The tide is out, and on the muddy flat at the mouth of the Almond you observe vast collections of rooks and gulls. Small flocks of ducks are swimming about in the stream, and groups of sandpipers are diligently probing the mud along 
its edges. Far away, at a safe distance, are many curlews and oyster-catchers. But see, scattered all over the sand, running with a half-hopping motion, and as they rise on wing displaying the white of their wings and tail, the beautiful snow buntings. At the edge of the water stand in a fixed and watchful posture a pair of herons; and, out at sea, are seen here and there a few dark-coloured birds, which may be cormorants or ducks. A flight of sandpipers is a beautiful sight; there they wheel around the distant point, and advance over the margin of the water; swiftly and silently they glide along; now, all inclining their bodies to one side, present to view their under surface, glistening in the sunshine; again, bending to the other side, they have changed their colour to dusky grey; a shot is fired, and they plunge with an abrupt turn, curve aside, ascend with a gliding flight, and all, uttering shrill cries, fly over the stream to settle on the shore that stretches out towards Barnbogle ruins. I have seen the sand fords of the Hebrides in autumn, when those birds descend with their broods from the moors, almost completely covered with them and the golden plovers.

What interest one could find in merely describing the skins of these birds in his closet, it is somewhat difficult to imagine; nor is it obvious that the examination of their structure, without any reference to their habits, is a much more rational occupation. The mere closet-naturalist, and the mere anatomist, find little to interest them in such a sight as this; 
and the mere field-naturalist, however delighted with it, cannot enjoy that true pleasure which results from a knowledge of the adaptation of means to ends, by which all these species have their peculiar spheres of action determined.-British Birds, vol. i., pp. 301, 302.

\section{7.-On Clisheim in a Snow-Storm.}

Having in October 1817, as I find by one of my note-books, left Borve in Harris, in company with the Reverend Mr Alexander Macleod, minister of the Forest district, I crossed the sand ford and hills of Luskentir to the little Bay of Kindibig, where we lodged with a farmer, who next day ferried us over Loch Tarbert to a place called Urga. We remained there for a night, and then continued our journey, proceeding up a long, craggy, and bleak valley, in which is a very darkcoloured lake, famous for a goblin-beast which is seen upon it in summer in the form of a black mass having three humps. The wind was exceedingly keen, the hail came in great showers, and the summits of the mountains were covered with snow. I left the parson a little above Marig, a creek on Loch Seaforth, in which was his dreary-looking habitation, and having resolved to ascend the highest hill, in order to witness a Hebridian snowstorm in all its glory, I proceeded towards Clisheim, 
the height of which is estimated at somewhat more than three thousand feet. In despite of hail and snow, and the furious whirlwinds or eddying blasts that swept the mountain at intervals, I made my way, though not without labour, to the summit; and well was I recompensed, for there I enjoyed a very sublime spectacle. I was on the highest pinnacle of that range of islands denominated the Outer Hebrides or Long Island, perched, like a ptarmigan, on a craggy and precipitous ridge. The islands of Uist, Harris, and Lewis lay, as it were, at my feet. Toward the east and south, in the extreme distance, appeared the mountains of the counties of Ross and Inverness, with the pointed hills and craggy capes and sloping plains of Skye. Westward, a long series of summits, commencing with that on which I stood, and forming a broad ridge, intercepted transversely by deep valleys, extended for several miles. They appeared to be much lower than the mountain on which I was, and resembled heaps of sand formed by pouring it from a vessel. The snow lay rather deep on them all, and the whirlwinds that swept along their ridges, scattering it in spiral flakes, presented an indescribably beautiful and sublime appearance. I was enveloped in one, but it did not prove very boisterous. The Atlantic was covered with huge clouds, that advanced in disorderly groups, nearly on a level with my position, but the waving streams of snow and hail that poured from them left no trace on the stormy waters. Toward the north lay 
the dreary flats of Lewis, covered with lakes and flanked with the Park and Uig mountains. Having gazed upon the splendid scene until nearly frozen, I descended with considerable difficulty into a deep valley, where $I$ encountered a fall of snow so dense as to render me apprehensive of being smothered by it. I felt too, for the first time perhaps, the benumbing effects of cold, my feet and fingers having become almost senseless, and a feeling of faintness having crept over me. However, by walking and running I soon recovered heat enough, and after passing the deep glen of Langadale, ascended an eminence in a kind of pass between two mountains, whence I discovered tokens of cultivation at the distance of three or four miles.British Birds, vol. i., pp. 306, 307.

\section{8.-Crossbills Feeding}

In the autumn of 1821 , when walking from Aberdeen to Elgin, by the way of Glenlivet and along the Spey, I had the pleasure of observing, near the influx of a tributary of that river, a flock of several hundreds of crossbills busily engaged in shelling the seeds of the berries which hung in clusters on a clump of rowan trees. So intent were they on satisfying their hunger that they seemed not to take the least heed of me, and as I had not a gun, I was content with gazing on them, 


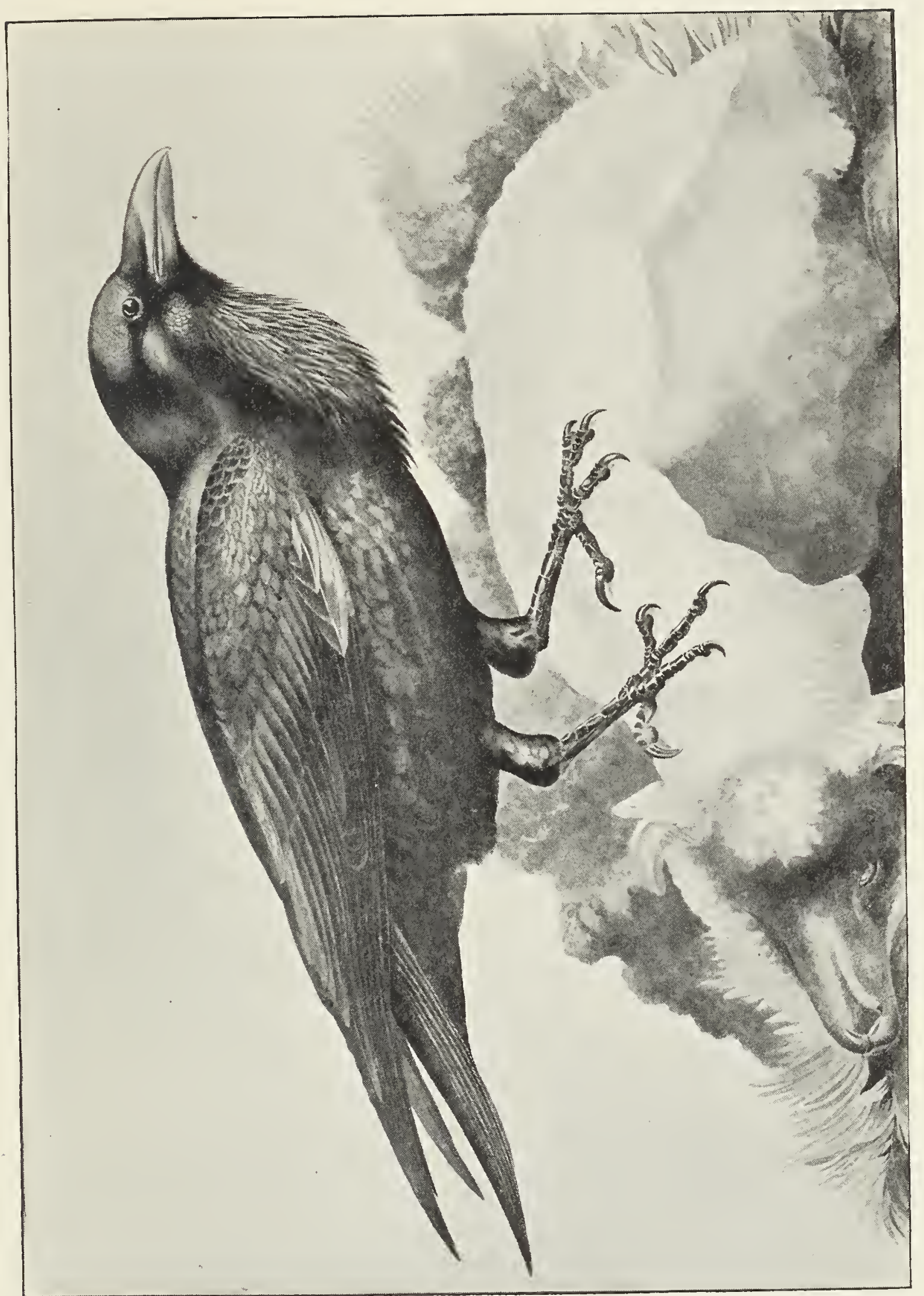

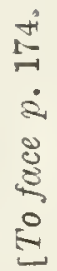

章 

without offering them any molestation. They clung to the twigs in all sorts of positions, and went through the operation of feeding in a quiet and business-like manner, each attending to his own affairs without interfering with his neighbours. It was indeed a pleasant sight to see how the little creatures fluttered among the twigs, all in continued action, like so many bees on a cluster of flowers in sunshine after rain. Their brilliant colours, so much more gaudy than those of our common birds, seemed to convert the rude scenery around into that of some far distant land, where the redbird sports among the magnolia flowers.-British Birds, vol. i., p. 425.

\section{9.--The Raven in the Hebrides.}

The character of the raven accords well with the desolate aspect of the rugged glens of the Hebridian moors. He and the eagle are the fit inhabitants of those grim rocks; the red grouse, the plover, and its page, of those brown and scarred heaths; the ptarmigan, of those craggy and tempest-beaten summits. The red-throated diver and the merganser, beautiful as they are, fail to give beauty to those pools of dark-brown water, edged with peat banks, and unadorned with sylvan verdure. Even the water-lily, with its splendid white flowers, floating on the deep bog, reflects no glory on the 
surrounding scenery, but selfishly draws all your regards to itself. There, on the rifted crag, let the dark raven croak to his mate, while we search for the species in distant parts of the land.-British Birds, vol. i., p. 509.

\section{0.- Scene on an April Day.}

It is a lovely April day. All over the pale blue sky are scattered fleecy tufts of white vapour, buds of beauty are bursting from the earth, and the distant waterfall fills the valley with its soothing murmur. How delightful the scenery of these wild hills, where from the rift of the lichencrusted crag juts out the rowan, whose elegantly pinnated foliage is fast unfolding; where, scattered along the broken steep, are seen the whitestemmed birches, with their drooping twigs and glistening leaflets; while the hillocks are crowned with blossomed furze; and the smooth waters of the deep lake send back the wooded banks and the heath-clad heights!

High overhead wheels in wanton mazes the joyous snipe, piping its singular song, and anon drumming on tremulous wing, as it shoots aslant. The shrill scream of the curlew is responded to by the wail of the lapwing and the melancholy whistle of the golden plover. Already have these birds deposited their eggs on the moor, in which they have scraped a slight hollow for the purpose of 
receiving them. Should you come upon one of their nests, you will admire the arrangement of its four pear-shaped and spotted eggs, the narrow ends of which meet in the centre. Among the tufts of furze and sloe hops the lively ring ouzel, newly arrived from the warmer region in which it has passed the winter; and by the pebbly margin of the pool flits the delicate sandpiper, whose body is continually vibrating as if on a pivot.

It is the busy season of Nature. What myriads of flowers are silently expanding; what rills of vegetable juices are ascending the stems of the topmost twigs; what mighty preparations, without confusion or bustle, are making to secure an abundant produce of fruit and seed for the support of animal life! How beautiful the brooding mystery of that happy raven, seated on her nest to impart vital warmth to her newly-fledged young, while her mate croaks in joy on the projecting crag, ready to sally forth and drive away the prowling hawk that may chance to come near his ancient seat, the castle of his sires! For weeks might one wander among those wooded glens, finding each hour some fresh object to excite admiration, and warm his bosom with the glow of gratitude toward the Supreme Power which out of nothing has called all these wonders into being. But at present we are mere strolling naturalists, bent on collecting nests and eggs._British Birds, vol. i., pp. 616,617 . 
11.-Some of Professor MacGillivray's FRIENDS.

I remember. Mr Weir is an enthusiast, a lover of Nature, and, although a Conservative and a trapper of birds, a Christian and a scholar. I forgot him when I boasted of having fought my way with my own claymore. You shall see presently how efficient his aid has been. Other friends too, still dearer, I overlooked, especially him who now, in some Canadian wilderness, is making room for himself and his family, beset perhaps with murderous rebels and renegades, my best and most beloved friend, William Craigie; and him too, of sultry Louisiana, the wanderer of the wild woods, the warm-hearted and generous Audubon; and many more, some of whom I shall have occasion to mention, but above all, one who will presently welcome us, for here, No. 1 Wharton Place, we end our digression for the present.British Birds, vol. ii., p. 13.

12.-The Song of the Blackbird.

Although the blackbird sings at all times of the day, it is more especially in the mornings and evenings that it pours forth its delightful melodies, which, simple as they are, I am unable to describe in a more effective manner than by characterising 
them as loud, rich, mellow, and much surpassing in effect those of any other native bird, excepting the nightingale, song thrush, black-cap, and garden warbler. I have heard individuals singing most fervently in the midst of a heavy thunder-storm, when the rain was falling thickly, and the lightning flashing at an alarming rate; and both this species and the song thrush seem to regard the summer rains with pleasure.

The sweet strain, loud, but mellowed by distance, comes upon the ear, inspiring pleasant thoughts, and banishing care and sorrow. The bird has evidently learned his part by long practice, for he sings sedately and in the full consciousness of superiority. Ceasing at intervals, he renews the strain, varying it so that although you can trace an occasional repetition of notes, the staves are precisely the same. You may sit an hour or longer, and yet the song will be continued; and in the neighbouring gardens many rival songster's will sometimes raise their voices at once, or delight you with alternate strains. And now, what is the purpose of all this melody? We can only conjecture that it is the expression of the perfect happiness which the creature is enjoying, when, uncarked by care, conscious of security, and aware of the presence of his mate, he instinctively pours forth his soul in joy and gratitude and love. He does not sing to amuse his mate, as many have supposed, for he often sings in winter, when he is not yet mated; nor does he sing to beguile his 
solitude, for now he is not solitary; but he sings because all his wants are satisfied, his whole frame glowing with health, and because his Maker has gifted him with the power of uttering sweet sounds.-British Birds, vol. ii., pp. 89, 90.

\section{3.-The Song of the Thrush.}

The song thrush is associated in my memory with the Hebrides, where it is perhaps more abundant than in most parts of Britain. There, in the calm summer evening, such as for placid beauty far exceeds any that I have elsewhere seen, when the glorious sun is drawing towards the horizon, and shedding a broad glare of ruddy light over the smooth surface of the ocean; when the scattered sheep, accompanied by their frolicsome lambkins, are quietly browsing on the hills; when the broad-winged eagle is seen skimming along the mountain ridge, as he wends his way toward his eyry on the far promontory; when no sound comes on the ear save at intervals the faint murmur of the waves rushing into the caverns and rising against the faces of the cliffs; when the western breeze, stealing over the flowery pastures, carries with it the perfume of the wild thyme and white clover; the song of the thrush is poured forth from the summit of some granite block, shaggy with grey lichens, and returns in softer and sweeter modulations from the sides of the heathy mountains. 
There may be wilder, louder, and more marvellous songs, and the mocking bird may be singing the requiem of the Red Indian of the Ohio, or cheering the heart of his ruthless oppressor, the white man of many inventions; but to me it is all-sufficient, for it enters into the soul, melts the heart into tenderness, diffuses a holy calm, and connects the peace of earth with the transcendent happiness of heaven. In other places the song of the thrush may be lively and cheery; here, in the ocean-girt solitude, it is gentle and soothing; by its magic influence it smoothes the ruffled surface of the sea of human feelings, as it floats over it at intervals with its varied swells and cadences, like the perfumed wavelets of the summer wind.-British Birds, vol. ii., pp. 130, 131.

\section{4.-The Carol of the Lark.}

The mellow song of the merle or mavis is apt to inspire melancholy, especially if heard in a sequestered valley toward the close of day, and the feelings which it excites have perhaps as much of a depressing as of a soothing tendency; but the carol of the lark, like the lively fife, excites pure cheerfulness, and might with propriety be prescribed as an antidote of dulness. It is not merely music that we look for in the song of birds, but variety, and the expression of passions, feelings, and wants. Were all our warblers to tune their throats accord- 
ing to rule, we should become sickly and sentimental, fill the valleys with sighs, and groan from the mountain tops; but the loud war-whoop of the eagle, the harsh scream of the heron, and the croak of the raven, are antidotes to the bewitching melody of the black-cap and nightingale. I have endeavoured to trace a repetition at regular intervals in the strains of the lark; but its modulations seem to have no rule. In confinement this bird sings every whit as well as when at large; and when rapidly perambulating the square bit of faded turf in its cage, it enacts its part with apparently as much delight as when mounting "towards heaven's gate."-British Birds, vol. ii., p. 170.

\section{5. - The Hen-Harrier.}

Having examined the form, and somewhat of the structure of the hen-harrier, we are prepared for the exhibition of its faculties. Kneel down here, then, among the long broom, and let us watch the pair that have just made their appearance on the shoulder of the hill. Leave these beautiful flowerets to the inspection of that lank-sided botanist, who drags himself slowly along, with a huge tin cannister on his back, and eyes ever bent on the ground. Should he wander hitherward, he will be delighted to cull the lovely tufts of maidenpinks that surround us; but we look heavenward, like the astronomers. 
How beautifully they glide along, in their circling flight, with gentle flaps of their expanded wings, floating, as it were, in the air, their halfspread tails inclined from side to side, as they balance themselves, or alter their course! Now they are near enough to enable us to distinguish the male from the female. They seem to be hunting in concert, and their search is keen, for they fly at times so low as almost to touch the bushes, and never rise higher than thirty feet. The grey bird hovers, fixing himself in air like the kestrel; now he stoops, but recovers himself. A hare breaks from the cover, but they follow her not, though, doubtless, were they to spy her young one, it would not escape so well. The female now hovers for a few seconds, gradually sinks for a short space, ascends, turns a little to one side, closes her wings, and comes to the ground. She has secured her prey, for she remains concealed among the furze, while the male shoots away, flying at the height of three or four yards, sweeps along the hawthorn hedge, bounds over it to the other side, turns away to skim over the sedgy pool, where he hovers a short while. He now enters upon the grass field, when a partridge springs off, and he pursues it with a rapid, gliding flight like that of the sparrow-hawk; but they have turned to the right, and the wood conceals them from our view. In the meantime the female has sprung up, and advances, keenly inspecting the ground, and so heedless of our presence that she passes within 
twenty yards of us. Away she speeds, and in passing the pool again stoops, but recovers herself, and, rising in a beautiful curve, bounds over the plantation, and is out of sight.-British Birds, vol. iii., pp. 371,372 .

\section{6. - The Golden Plover.}

Many a time and oft, in the days of my youth, when the cares of life were few and the spirits expansile, and often, too, in later years, when I had made a temporary escape to the wilderness to breathe an atmosphere untainted by the effluvia of cities, and ponder in silence on the wonders of creative power, have I stood on the high moor and listened to the mellow notes of the plover, that seemed to come from the grey slopes of the neighbouring hills. Except the soft note of the ringplover, I know none so pleasing from the grallatorial tribes. Amid the wild scenery of the rugged hills and sedgy valleys, it comes gently and soothingly on the ear, and you feel, without being altogether conscious of its power, that it soothes the troubled mind, as water cools the burning brow. How unlike the shriek of the heron-but why should we think of it, for it reminds us of the cracked and creaking voice of some village beldame of the Saxon race. The clear, gentle tones of the Celtic maiden could not be more pleasant to any one, or perhaps much more welcome to her lover, than the 
summer note of the golden plover to the lover of birds and of Nature. As you listen to it, now distant, now nearer and near, and see the birds with short flights approaching as if to greet you, though in reality with more fear than confidence, with anxiety and apprehension, the bright sunshine that glances on their jetty breasts is faintly obscured by the white vapours that have crept up from the western valley, and presently all around us is suffused with an opaline light, into the confines of which a bird is dimly seen to advance, then another, and a third. Who could represent the scene on canvas or card?-a hollow hemisphere of white shining mist, on which are depicted two dark human figures, their heads surrounded with a radiant halo, and these black-breasted golden plovers, magnified to twice their natural size, and gazing upon us, each from its mossy tuft. It is as if two mortals had a conference on the heath with three celestial messengers-and so they have. Presently a breeze rolls away the mist, and discloses a number of those watchful sentinels, each on his mound of faded moss, and all emitting their mellow cries the moment we offer to advance. They are males, whose mates are brooding over their eggs, or leading their down-clad and toddling chicks among the, to them, pleasant peat-bogs that intervene between the high banks, clad with luxuriant heath, not yet recovered from the effects of the winter frosts, and little meadows of cotton-grass, white as the snow-wreaths that lie on the distant 
hill. How prettily they run over the grey moss and lichens, their little feet twinkling, and their full, bright, and soft eyes gleaming, as they commence their attempts to entice us away from their chosen retreats. In the midst of them alight some tiny things, black-breasted too, with reddish backs and black nebs and neat pointed wings, which they stretch right up, and then fold by their sides. These are plovers' pages, which also have their nests on the moor. The mist rolls slowly away, and is ascending in downy flakes the steep side of the corrie, whence comes suddenly on the ear the loud scream of the curlew-pleasing too, but to the deer startling. The fewer of these birds on the moors after the 12th of August, the better for the deerstalker; but that day is far distant.-British Birds, vol. iv., p. 97.

\section{7.-The Common Ring-Plover.}

Were I to describe the manners of this gentle creature under the influence of the delightful emotions which the view of it has often excited in me, I should probably appear to the grave admirer of Nature an enthusiast, or an imitator of other men's musings. Well, let him think as he lists; but yet lives there the man, calling himself an ornithologist, who, quietly strolling along the bright sandy beach just left bare by the retiring tide, and aroused from his pleasing reveries by the mellow. whistle of the 
ring-plover, would not gaze with delight on the pleasant little thing that speeds away before him with twinkling feet, now stops, pipes its clear cry, runs, spreads its beautiful wings, glides close over the sand, and alights on some not distant tuft. What are primaries and secondaries, coecums and duodenums, types and analogies, squares or circles, to him who thus watches the living bird? There is the broad blue sea, on that hand the green pasture, under foot and around the pure sand, above the sunny sky. Frown not upon the cheerfulness of Nature; shout aloud, run, leap, make the sand lark thy playmate. Why mayest thou not be drunk with draughts of pure ether? Are the gambols of a merry naturalist less innocent than the mad freaks, the howlings, the ravings of sapient men assembled to deliberate about corn-laws, or party zealots upholding their creed by palpably demonstrating their total want of charity ?-British Birds, vol. iv., p. 119.

18.-The Sea-Pie.

Should one consider the sea-pie the most beautiful of our native birds, I should not much censure his taste. When by the silver Dee, gliding, rapidly along, amidst corn-fields, pastures, and fragrant birch-woods, you hear a loud and shrill cry, and, turning about, see a pair winging their flight up the country, their glossy black and pure 
white plumage contrasting strongly with everything around, and their long vermilion beaks giving them a strange and foreign aspect, they never fail to rivet your gaze. Equally attractive are they when running aboút on some grassy meadow, picking up an insect or a slug, then standing, and again advancing with quick, short steps, prettily tripping it among the gowans; then emitting their loud alarm-cries, and flying off to a more distant place, or alighting on a pebbly beach. No creature but man seems to molest them; but of his advances they are always suspicious, as good need they have to be.-British Birds, vol. iv., p. 158.

\section{9.-Dunlins Feeding.}

I, on the 9 th of September 1840, walked to Musselburgh, where I was informed that the sandpipers were very abundant; and, having betaken myself to the mouth of the Esk soon after the tide had turned, was gratified by the sight of a great number of dunlins and ring-plovers. In the first place I met with two flocks reposing, the one among some thin herbage, composed chiefly of Glaux maritima; the other on a slightly elevated part of the sand, just above water-mark. Individuals of both species were intermingled, all lying flat on the ground, and in a crouching attitude, with the neck drawn in. Thus, as I have elsewhere observed, these birds repose during the period of 
high water in unfrequented places along the shore, and generally, especially if there be a strong wind, in a decumbent posture. On my approaching them, they dispersed, and began to search for food. Presently straggling bands flew in from a distance and alighted on the shore. The dunlins on such occasions come gliding on outspread wings, which in alighting they extend and elevate a little. They then run a few steps, and stand a short time, or at once commence their search. These bands were remarkably intent on seeking for food, so that I was allowed to walk up to about fifteen paces from one of them. In this flock of about fifteen, two limped, apparently having had one of their legs damaged by shot, yet they seemed scarcely less active than the rest. Being in a muddy place, which probably afforded a good supply of food, they did not run much, but yet moved quickly about, with their legs a little bent, the body horizontal, the head a little declined, and the bill directed forwards toward the ground at an angle of about forty-five degrees. I observed that they seemed in general merely to touch the surface, but also sometimes to introduce their bill into the mud for about a fourth of its length; but this always with a rapid tapping and somewhat wriggling movement, and not by thrusting it in sedately. This flock having flown away, I observed another of about twelve individuals alight at a little distance on the other side of the mill-stream. Being very intent on tapping the mud, they allowed 
me to approach within ten paces, so that I could see them very distinctly. I was surprised to hear from them a very gentle warble, which was composed of feeble notes somewhat resembling the syllables pee-pee-pee, continually repeated, and with more frequency when the individuals came very near each other. These notes could not be heard at a greater distance than twenty yards, and would thus be entirely lost to the casual observer. All at once I heard a singular noise, which might be likened to a cough, shrill and feeble as it was, and presently found that it came from one which, having picked up something too large for its gullet, stood endeavouring to swallow it by repeated jerks, at each of which it emitted a sharp wheezing or hissing sound. The rest paid no attention to the distressed bird, which in about three minutes got the morsel down, and resumed its search. While thus busily employed, and quite regardless of me, although so near that I could see their little dusky eyes, and distinguish by its tints one individual from another, a sandpiper, Totanus hypoleucos, came silently gliding over them at the height of not more than three feet. It was beautiful to see how they all rose simultaneously on wing to the height of from two to four feet, and, finding that they had no cause of alarm, immediately re-alight. I now struck my note-book against my hand, when they all rose, but alighted about five yards off, and three of them came within ten paces of me. As nothing more was to be seen, I examined the marks made 
by them in the mud. Although it was soft, very few footmarks were left; but the place was covered with numberless small holes made by their bills, and forming little groups, as if made by the individual birds separately. Of these impressions very many were mere hollows not larger than those on a thimble, and not half a twelfth of an inch deep; others scarcely perceptible, while a few were larger, extended to a depth of two-twelfths; and here and there one or two to the depth of nearly half an inch. On scraping the mud I could perceive no worms or shells. It is thus clear that they search by gently tapping, and it appears that they discover the object of their search rather by the kind of resistance which it yields than by touch like that of the human skin.-British Birds, vol. iv., p. 210.

\section{0.-The Common Snipe.}

Beautiful are those green woods that hang upon the craggy sides of the fern-clad hills, where the heath-fowl threads its way among the tufts of brown heath, and the cuckoo sings his ever-pleasing notes as he balances himself on the grey stone, vibrating his fan-like tail. Now I listen to the simple song of the mountain blackbird, warbled by the quiet lake that spreads its glittering bosom to the sun, winding far away among the mountains, amid whose rocky glens wander the wild deer, 
tossing their antlered heads on high as they snuff the breeze tainted with the odour of the slowpaced shepherd and his faithful dog. In that recess formed by two moss-clad slabs of mica-slate, the lively wren jerks up its little tail, and chits its merry note, as it recalls its straggling young ones that have wandered among the bushes. From the sedgy slope, sprinkled with white cotton-grass, comes the shrill cry of the solitary curlew; and there, high over the heath, wings his meandering way the joyous snipe, giddy with excess of unalloyed happiness.

There another has sprung from among the yellow flowered marigolds that profusely cover the marsh. Upwards slantingly, on rapidly vibrating wings, he shoots, uttering the while his shrill twonoted cry. Tissick, tissick, quoth the snipe, as he leaves the bog. Now in silence he wends his way, until at length, having reached the height of perhaps a thousand feet, he zigzags along, emitting a louder and shriller cry of zoo-zee, zoo-zee, zoozee, which over, varying his action, he descends on quivering pinions, curving toward the earth with surprising speed, while from the rapid beats of his wing the tremulous air gives to the ear what at first seems the voice of distant thunder. This noise some have likened to the bleating of a goat at a distance on the hillside, and thus have named our bird the air-goat and air-bleater. The sound, I think, is evidently produced by the rapid action of the wings, which, during its continuance, are seen 
to be in tremulous motion. It comes on the ear soon after the bird commences its descent, and ceases when, having gained the lowest part of the curve, it recovers itself, and ascends with a different and ordinary motion of its wings. I have never heard it under any other circumstances. Were it produced by the voice, it might be emitted when the bird is on the ground, or during its ordinary flight; but should one hear it on the moor, he will invariably find that it proceeds from on high. In this manner the snipe may continue to amuse itself for, perhaps, an hour or more; and sometimes, in the clear sky, one may trace it until at length it mounts so high as to be no longer perceptible.

This drumming noise of the snipe commences in April and is continued through the summer. It is altogether a solitary act, although several individuals may often be heard at the same time, and may be an expression of the happiness of the bird, or an intimation of its presence to its mate while sitting upon her eggs. We have no means of ascertaining its object, nor has it been determined whether it be performed by the male only, or by the female also. When the bird has gone through his evolutions, he descends, often with astonishing velocity, on partially extended and apparently motionless wings, diminishes his speed a little as he approaches the ground obliquely, and alights abruptly._British Birds, vol. iv., p. 371. 


\section{1.-The Grey Heron.}

Far away through the green valley winds the silver Tweed, now rolling its waters over the white pebbles, then gliding placidly between banks covered with fresh herbage and gaudy florets of many hues. The hum of the wild bee draws your eye toward those beautiful tufts of purple trefoil; the weet-weet, ever vibrating its body as if delicately balanced on its slim legs, runs along the sunny beach, spreads out its pointed wings, and skims over the pool. There, in the water, nearly up to the knees, is the heron, patiently waiting an opportunity of seizing some giddy trout. Those ducklings that swim so beautifully, and dive with such marvellous quickness, he seems to eye with hungry glance; but their watchful protectress is in the midst of them. That wary old water-rat is equally safe, as he nibbles the grass at the mouth of his hole, and at intervals trims his whiskers with his little paws. In short, go where you will, in summer or in winter, to the shores of the sea or the far inland lake, the source of the estuary of the hill-born streams, you may here and there find a solitary heron.-British Birds, vol. iv., p. 445.

\section{2.-The Great Black-Backed Gull.}

It is a lovely night in June; the moon slowly emerges from behind the distant mountains, the 
northern horizon is still red with the glare of the departed sun, the winds have sunk to rest, and no sound is heard save the faint murmur of the waves that clash over the distant reefs. Yet, hark! the terns are abroad, and their shrill cries come faintly on the ear, from the far-off sand-point, where, no doubt, they are engaged with a shoal of launces. Listen again! The oyster-catchers intermingle their clamorous and curiously modulated cries; and now, louder than all, is clearly heard the call of the black-backed gull, faintly seen in the dim light. Here is one of his breeding-places, a turf-crowned crag, torn, as it were, from the rocks, and forming an inlet inaccessible to human feet. Creeping stealthily among the crags, we faintly perceive the birds as they sit on their nests; but some of them have observed us. All spring on their feet, and a few launch into the air, uttering loud cries, which alarm the birds around. It is vain, you perceive, to try to surprise them by night or by day. Wander as long as you will in these places, what more can you see? Perhaps a more acute observer may.British Birds, vol. v., p. 534 .

\section{3.-Promise of a Bright Day.}

The dawn of this 7th of August gave promise of a bright day. How beautiful is the quiet valley as it basks in the sunshine. The corn-fields, some nearly ready for the sickle, others yet green, are 
spread out by the margin of the river, which glides along in its winding course, emitting a pleasing murmur, excepting which the ear catches no sound; for the air is still, and even the hair-grass waves not its slender panicle. The cattle are feeding on the after-grass; here and there a peasant is seen in the fields, or near the few cottages scattered over the valley; but otherwise all is very still, and in the gentle beauty of the scene one hardly sees a place for human wickedness. If it is not a paradise we gaze upon, it is a scene well fitted to remind us of how much happiness our earthly habitation might yield were it always illuminated by a sense of the Divine presence.-Natural History of Deeside, p. 49.

\section{4.-LOCHNAGAR:}

Still onward, amidst woods and mountains, and here and there fields, yielding the staple food of the Scot. Let us again look southward, "o'er moors and mosses mony," to the never-tiring glories of Lochnagar, which is now much nearer to us than when we first saw it. Like Edinburgh, it may be viewed with interest from any station. For my part, I could gaze a quarter of an hour on either every day of the year without getting tired. There, proudly pre-eminent over all around, just as it settled when it was heaved up from the abyss, it stands in solemn grandeur, its ridges wreathed in 
white vapour. Lochnagar has more dignity than any of our hills, except Ben Nevis.-Natural History of Deeside, p. 55.

\section{5.-View from Invercauld Bridge.}

At length we stand on the lofty mid-arch of Invercauld Bridge. Before we pass on, let us pause once more-not because we are weary of travel or of the world. Here the bed of the Dee is obliquely intercepted by a broken ridge of slaty rock, passing from south-west to north-east. The stream is broken by it into a succession of little falls and rapids, and then glides away over its stony bed to wind afar amidst pine-clad hills. Beautiful scene! I almost weep when I look upon thee; for tears flow from the pure fountain of happiness as well as from the troubled springs of sorrow. How unlike, in thy quiet loveliness, to the fierce rudeness of human nature! Not a living creature is to be seen but a lad whipping the water. The western sun shines in full splendour in a sky unobscured, although scattered flakes of white vapour glide slowly eastward in its upper region. Long shadows are projected from the tall pines, while the hill-tops, purpled with flowering heath, or grey with lichencrusted stones, are lighted with the blaze. Far away up the wooded glens is still seen the scarred ridge of Lochnagar. Not a breath stirs the tiny leaf of the birch, nor a sound is heard but from the 
waters. Ought not he to whom Providence has allotted all this to be happy? The scene is mine and thine; but happiness comes not from without. Yet, O Invercauld! thou hast a patrimony of beauty. May it long be enjoyed by thee and thine. I see nothing wanting but scattered homes of happy tenants, and little patches of yellow corn, and cows feeding by the river, and sheep on the hills._Natural History of Deeside, p. 56 .

\section{6.-ObJect of the Study of Nature.}

Our objects in examining the stone, the rock, the lichen, the moss, the flower, the fruit, the insect, the bird, or the quadruped, is to exercise our faculties by learning how beautifully, and with what wisdom all things have been constructed, how wonderfully they are formed with relation to each other, and how manifestly they display a power of which we could form no conception were we not to attend to its working as exhibited by them. It is true, we cannot fully comprehend the complicated relations of the most common objects, much less understand the ordination of the universe, or even of our own world; but we labour in hope; we are studyingsome of us, no doubt, very superficially, others more profoundly-the works of the Deity; and the more progress we make, the more we glorify Him by an intelligent, not a vague, admiration. There are some who aim at the knowledge of general laws, some who seek simple facts. Both parties 
will find enough to engage their faculties, and neither will do the work of the other efficiently. There is no reason why one should despise the other. Contempt of anything but vice indicates an unsound mind, a defective judgment, an ignorance of the relations which men have to each other and to their Creator, an undue self-estimation, and a contempt of the rights of other men. He who measures the orbit of a comet has not, therefore, higher faculties than he who examines the cytoblast of a fungus; and there is far more to be seen by us in a beetle than in a planet; upon that granite mountain opposite, at the distance of nine or ten miles, than in the sun and in the moon and the stars.-Natural History of Deeside, p. 120.

\section{7. - The Scenery of Benabuird.}

On reaching the summit, I found it to be a long, broad, rounded ridge, covered with stones, some of which were rounded, others angular. Here were a few mosses and a considerable quantity of Carex rigida. The scene which here presented itself was exceedingly striking and impressive. All arıund, mountains appeared behind mountains, with their rocks, ridges, and valleys. A solemn stillness prevailed; nor was a living creature to be seen; the clouds rolled their dusky wreaths along the ridges. The beams of the setting sun darted here and there through the clouds, which exhibited a hundred ever-varying shades. 
In one direction a vast livid mass hung over the ridges of a mountain, its lower fringed margin beautifully tinged with deep crimson. In another place the white vapour which clung to the summits of the mountains assumed, where opposed to the sunbeams, a roseate hue of the greatest delicacy. From a small lake in a rocky corrie, five or six miles distant, a white streamlet poured down an Alpine valley bounded by precipitous crags. In the west, through an opening of the clouds, was seen a range of lofty mountains, rising behind each other, the most distant being probably fifty miles off. To the west and north-west the mountains continued undiminished in size as far as the eye could reach, but to the east they rapidly diminished. The desolate ranges of Braemar have a solemn grandeur independently of atmospheric drapery, but partially enveloped in massy clouds, or overhung with a wavy curtain of gorgeously tinted vapour, their glories are superbly enhanced. But by degrees the purple and burnished gold and roseate hues faded away into dull bluish grey, dimness crept over the mountains, and my home was eight miles distant. - Natural History of Deeside, p. 124.

\section{8.-Aged Birch Trees.}

In ascending a valley towards the higher grounds, and after passing through a birch wood, you come upon scattered trees, having an aged 
aspect, and stunted dimensions. Some are yet vigorous in their old age; others, gnarled and knotted, with torn and ragged bark, partially denuded and decayed wood and thinly-clad branches. Many vicissitudes have these aged denizens of the forest seen: sunshine and gloom, calm and tempest; the enlivening heat of summer and the cramping frosts of winter have come over them-how often one cannot tell. In the midst of them has the half-savage Celt of the olden time shot his arrow into the stately stag; and but yesterday has the smooth-faced and trimly-clad Saxon sent from his rifle, as he leant against one of their trunks, the whizzing messenger of death to the herd that reposed in peace upon the mossy knoll. Farther on, many trees lie prostrate on the hillside among a scattered group of melancholy survivors; and yet farther up the valley the ground is covered with trunks, erect, but decayed, broken down, shaggy with moss and lichen, rotten to the core, and crumbling under the action of the weather. Said I not well, that trees harmonise with human feelings? He who for the hundredth time could pass by such a scene and not experience its depressing effect must have a heart unfit for any gentle emotion. A trumpet could not more forcibly proclaim the inevitable death of all organic being than do these lifeless and silent monuments of ruin.-Natural History of Deeside, p. 169. 


\section{9.-The Wind in the Beallach-bhui Forest.}

Once more in the Beallach-bhui forest, I seat myself on a mossy bank and gaze around. I am in the middle of a seeming amphitheatre of hills, formed of ranges extending from Craig Clunie, on the right, up to the crags of Lochnaneun, on the shoulder of Lochnagar, and a ridge descending, on the left, from that mountain down to the Dee. Beyond the river, northward, is seen the rugged and partly wooded face of a brown hill, forming a kind of corrie, and a pine wood extending from it. But that all on. that side may be excluded from the scene, we turn from it.

There is a sprinkling of birch in the lower parts of the forest, and here and there along the hills; but pines, stately and solemn, rear their columnar stems around, some of giant stature, but the greater number of ordinary size; all, however, healthy and vigorous. Here, in the wood, the sunbeams glance upon us; for there is no continuous obscuration of the sky by the foliage; but far up the valley, and along the hills, the trees seem crowded into masses of dark verdure. The breezes, as they sweep over the woods, sound like the noise of the ocean-wave, as they dash upon a distant rock. Suddenly a rushing sound is heard, coming from afar. It advances, and, as it passes by, resembles the roar of a mighty flood. A blast from the mountain-pass has swept over the forest, 
bending the stiff tops of the lofty pines. Were a hurricane, or even a winter tempest, to invade the valley, rending off the massy limbs, and prostrating the old trunks, the scene would be terrific. We may fancy, too, the magnificence of a protracted thunder-storm - impenetrable gloom over all the forests, lightnings blazing, and thunders crashing; but I have never found imaginary scenes so instructive as real occurrences, and that chiefly because they are radically unreal, and one knows them to be so. The wind has ceased, and the forest rests in solemn stillness. You can see far away into the forest, between the stems, which are destitute of branches to a great height. Here the ground is covered with luxuriant tufts of heather in full bloom; there the stones are coated with moss and lichens; and on that low knoll the continuous verdure is due to the yet fresh leaves of the Vaccinium myrtillus. - Natural History of Deeside, p. 178.

\section{0.-Merry-Making of Birds.}

The sun sent a gleam of light through the Pass of Ballater into the plain, and illumined the hilltops on the western side, while their shadows spread far over the fields. The hill along the base of which I walked is covered with pines, and partly, opposite the village, with birches. Great numbers of chaffinches flew along from tree to tree, 
apparently enjoying the sunshine, occasionally chasing each other, and engaging in mimic conflicts. I was drawn into the wood by hearing a singular chorus of many shrill voices in the trees, and, looking up, observed a multitude of little birds of several species frisking about in great glee. Most of them were coal-tits, ringlets, blue tits, and willow-wrens; but there were also many chaffinches, and some common linnets. Great numbers of ringlets occurred in other parts of the wood. I was amused with the movements of a pair of coaltits, which separated from the rest, and betook themselves to an excavation in the diluvium, from the turf margin of which there hung a number of slender tree-roots. One of the tits flew in among them, frisked from one to another, clung to a long filament, and appeared to enjoy the motion, as it swayed backwards and forwards. The other bird then joined it, and they seemed content for a while to amuse themselves apart from their companions. There was a general merry-making among the little birds. They seemed, after the labours of the day, old and young together, to indulge in frolic before retiring to rest.

Many species of mammalia, birds, and fishes, evidently pass a portion of their time in sport. Young animals are especially addicted to romping, as may be seen in foals, calves, and especially lambs and kids, as well as puppies and kittens. The same is observed in birds, wild and domestic, in hawks, rooks, finches, and poultry. No birds are more 
gracefully sportive than ducks of all kinds are on the water. Not the gentle only, but also the ferocious, enjoy themselves in this manner. Eagles and ravens I have often seen wheeling and gliding through the air in sport, while they gave expression to their delight in loud and modulated cries. Natural History of Deeside, p. 184.

\section{1.-The Highland Moor.}

Leaning against a cairn constructed of angular stones of grey porphyry, supplied by a heap close at hand, I survey an extensive tract of mountain and moor. The sun, shining clear in a cloudless pale blue sky, gives some warmth to my right side, while a breeze from the north-east comes whirling at times round the cairn, chilling me with its piercing blasts. It is the 4th of September, near sunset. I stand in the midst of a region which might be thought one of stillness and desolation, were it not that symptoms of human life are seen in five little patches of cultivated land, and a group of black huts in a hollow, from one to two miles distant. Yet the range of vision is not less than fifty miles in one direction. Just behind me are the summits of a hill range, not more than a mile distant, beyond which nothing is to be seen; and therefore I have turned my back upon them. To the left is a rounded hill, running down into a smooth ridge, over a depression in which are seen the hills 
beyond Ballater, topped by the conical summit of the more distant Mount Keen, singularly white in the pale rays of the western sun. Low ranges extend from it, until there rises, in the south, the massive form of Lochnagar-both its corries conspicuously displayed; the western illuminated, the eastern in deep impenetrable shade, veiled by a filmy grey vapour. A most beautiful undulated ridgy descent leads the eye to the Glen Ballater mountains, the Beallach-bhui, and the Braemar hills as far as the upper part of Glen Ey. The great mountain stands conspicuous in its massy breadth and towering height, as if upheaved beyond its ordinary elevation. At its base, near Loch Muic, is a large rounded hill; but elsewhere, all down to the Dee, the ground seems low, presenting only some undulations, which, although really of some considerable height, are scarcely noticeable from our present station. On this side of the Dee, the position of which is known only by recollection, is a range of low hills, undulated in its outline, but high enough to prevent us from seeing those hills that seemed mountains to us as we traversed the valley. Where the Braemar mingle with the Atholl ranges in the extreme distance, the horizon is next bounded by a roundish hill, only about five miles distant. Then Ben Aun rising behind, with its long unwaved, but curiously knobbed ridge, leads us to the blaze of the western sun, just passing behind the broad head of the Bho-dhoun, which, at only the distance of two miles, seems continuous with 
the hill on which we stand. The long shadows cast upon the grey and brown moors by the many prominences of the Lochnagar group have a singular and rather perplexing effect; for they give the wellknown tract an aspect different from any under which we have contemplated it, whether in the sunshine of noontide, the diffused light of a cloudy day, or when the summits, involved in vapours, hid themselves from our view, and the bases of the mountains seemed more massy than they ever do when their entire forms are disclosed.

But now, over the ridge of Ben Aun, creeps a thin and flaky mass of vapour, glowing on its northern side with a roseate tint; purplish rays diverge from behind the brown hill to our right; the white summit of Mona-Chuine has assumed a roseate hue, and Lochnagar is tinged with a pale purplish blue. Beautifully delicate are the tints of the few fleecy cloudlets that rise in the north-west; but the setting sun assumes no imposing glory, and as he passes on seems to smile a gentle good-night on the brown moors of Glen Gairn.

The red grouse call to each other on the hillside; here, a solitary grey hare bounds quietly among the short heather, stops to listen and look around, then pursues its way; some hooded crows, that have been prowling about, are flying down the little valley; dimness envelops the low grounds, then the bases of the hills, creeping upwards, slowly, imperceptibly, but surely, like age and time, ever moving onward, and involving all things 
in darkness. There is now no sound but the sighing of the breeze; and as we descend over the long smooth declivity, clad with thick heather, we pause not to listen to the hum of distant waterfalls, or the shriek of the white owl, for no torrents rush over these moors, nor ruined towers rise on the brown hills, where the gor-cock (Lagopus scoticus), escaped from the gun of the unpitying sportsman, crouches with the remnant of his family.-Natural History of Deeside, pp. 207, 208.

\section{2. - Three Pine Trees.}

Three stunted trees among rubbish have a most singular effect. One can hardly believe his eyes when they tell him they are pines. How came they there? What is their purpose? Why are there not more of them? How old are they? Very easy it is to ask questions which nobody can answer. A fourth tree has grown there also, but it lies overthrown, unbarked, and rotting. Their bent and rugged trunks indicate poverty and old age. Many storms of wind and rain have burst upon them; the sun has blazed fiercely upon their tufted foliage, and the parched crags have sent back his rays upon their spreading branches. The snows of winter have pressed them down, and the sapless soil has refused them nourishment in summer; their kindred have perished one by one; the last of their brethren lies prostrate beside 
them; they are the remnants of a once numerous and prosperous race, and when they perish there will be no monument but this passing notice to indicate that they once were.-Natural History of Deeside, p. 239.

\section{3.-Home.}

But it is now getting toward six o'clock, and, as my resting-place is a good way off, it is time to proceed. When I ascended the valley of the Dee, in the end of July, the woods rejoiced in the warm breezes, and spread their green foliage to the sun. Now, in the middle of September, they seem preparing for the winter; their discoloured and sapless leaves, smitten by the night-frosts and seared by the drought, show no gladness, but speak of decay-beautiful in its gradations, like the passage of the aged Christian to the grave, and very pleasing to the sobered and contemplative mind. I have this year seen these woods of Crathes, when their twigs bore nothing but buds, when their tender leaves were unfolding, when their foliage covered them as a mantle; and now, in passing, I observe them streaked and patched with the yellow tints of autumn. Winter will again strip them of all their vesture; but they "will hear the voice of spring and flourish green again." So shall we, whose life is Christ.

An easterly wind, not cold and penetrating, brings up the clouds successively from the Celtic 
sea. But scarcely any rain falls, and at intervals the moon is seen dimly defined through the grey vapour. Farmers are returning in carts and gigs from the market, it being Friday; but otherwise the road is dull, it being much less frequented at any time than that on the north side.

Not an inn nor a shop could I find anywhere, and having neither eaten nor drunk since twelve o'clock, I resolved, on reaching Maryculter, to make application for tea and bread, the favourite food of sedentary people, and assuredly the most invigorating of all to the wearied pedestrian. How much refreshed I felt after an hour's rest and a plentiful meal, any one may understand who has an elastic temperament. The milestones which I had been counting were no longer consulted; and as little of the well-known scenery was visible under the faint light of the moon, veiled by the grey vapours, I mused on many things as I walked quickly along.

The Divine Providence has rendered my path pleasant to me in the rugged corrie, in the thick wood, and in the green valley; has prepared friends to forward my views, to protect me under their hospitable roofs and instruct me by their conversation; has restored me to health, and preserved it to me; has enabled me to accomplish the purpose of my journey, and filled me with gratitude now that I approach its termination.

Kind reader! it is time to bid thee "Goodnight."-Natural History of Deeside, p. 305. 
34.-Scene at Torquay.

It is well that the observations from which these descriptions have been prepared were made many years ago, when I was full of enthusiasm, and enjoyed the blessings of health and freedom from engrossing public duties; for I am persuaded that now I should be in some respects less qualified for the task, more, however, from the failure of physical than of mental power. Here, on the rocky promontory, I shiver in the breeze which, to my companion, is but cool and bracing. The east wind ruffles the sea, and impels the little waves to the shores of the beautiful bay, which present alternate cliffs of red sandstone and beaches of yellow sand, backed by undulated heights and gentle acclivities, slowly rising to the not distant horizon, fields and woods, with villages and scattered villas forming-not wild nor altogether tame-a pleasing landscape which, in its summer and autumn garniture of grass and corn, and sylvan verdure, orchard blossom and fruit, tangled fence-bank and furze-clad common, will be beautiful indeed to the lover of Nature. Then the balmy breezes from the west and south will waft health to the reviving invalid. At present the cold vernal gales sweep along the channel, conveying to its haven the extended fleet of boats that render Brixham, on the opposite horn of the bay, one of the most celebrated of the southern fishing- 
stations of England. High over the waters, here and there, a solitary gull slowly advances against the breeze, or shoots athwart, or with a beautiful gliding motion sweeps down the aerial current. At the entrance to Torquay are assembled many birds of the same kind which, by their hovering near the surface, their varied evolutions and mingling cries, indicate a shoal, probably of atherines or sprats. On that little pyramidal rock, projecting from the water, repose two dusky cormorants; and, far away, in the direction of Portland Island, a gannet, well known by its peculiar flight, winnows its exploring way, and plunges headlong into the deep. But neither time nor place are favourable to the observation of the wading tribes, although the country around supplies the greater number of those found in Britain._British Birds, vol. iv., p. viii.

\section{5.- "Conclusion."}

I have finished one of the many difficult and laborious tasks which I had imposed upon myself. Twelve years have elapsed since the first three volumes of this work were issued to the public, and I had scarcely hoped to see its completion, when I was most unexpectedly encouraged to revise the manuscript of the two remaining volumes, containing the wading and swimming birds, of which the history, in so far as I am 
acquainted with it, is now given on the same plan as that adopted for the land birds. Commenced in hope, and carried on with zeal, though ended in sorrow and sickness, I can look upon my work without much regard to the opinions which contemporary writers may form of it, assured that what is useful in it will not be forgotten, and knowing that already it has had a beneficial effect on many of the present, and will more powerfully influence the next, generation of our homeornithologists. I had been led to think that I had occasionally been somewhat rude, or at least blunt, in my criticisms; but I do not perceive wherein I have much erred in that respect, and I feel no inclination to apologise. I have been honest and sincere in my endeavours to promote the truth. With death, apparently not distant, before my eyes, I am pleased to think that I have not countenanced error through fear or favour. Neither have $I$ in any case modified my sentiments so as to endeavour thereby to conceal or palliate my faults. Though I might have accomplished more, I am thankful for having been permitted to add very considerably to the knowledge previously obtained of a very pleasant subject. If I have not very frequently indulged in reflections on the power, wisdom, and goodness of God, as suggested by even my imperfect understanding of His wonderful works, it is not because I have not ever been sensible of the relation between the Creator and His creatures, nor because my chief enjoyment, 
when wandering among the hills and valleys, exploring the rugged shores of the ocean, or searching the cultivated fields, has not been in a sense of His presence. "To Him who alone doeth great wonders" be all glory and praise. Reader, farewell !-British Birds, vol. v., "Conclusion."

"Iervant of Bod, well Done."

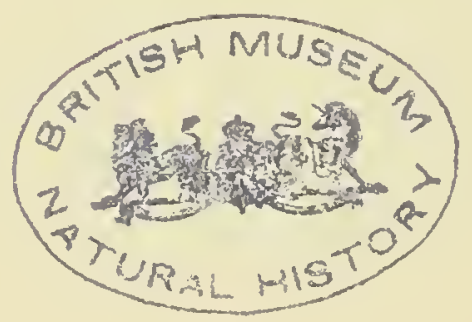




\section{N D E X}

ABB's Head, St, 159

Aberarder, 33

Aberdeen, 1, 4 ; King's College, 6 ; to London, walk from, 26-52 ; Marischal College and University, 58, 84, 97, 115, 116 ; mural memorial tablet presented to, 3, 151 ; Natural History Society in, 155; Notes taken in the Course of a Journey from Aberdeen to London, 2

Achlossan, Loch of, 125

Adams, Andrew Leith, his studies in natural history, 153

Alauda pratensis, 31

Albans, St, 52

Albyn, mountains of, 39

Alleghanies, heights of the, 168

Almond, a winter bird scene at the mouth of the, 170

Ambleside, 44

America, 65

Anderson, James, 153

Animals, sports of, 204

Annan, 38

Ant-hills, size of, 128

April day, scene on an, 176

Archipelago, Eastern, 111

Arthur's Seat, 161

Ashbourne, 49

Atherines or sprats, shoal of, 212

Atholl ranges, 206

Auchterless, parish of, 6

Audubon, John, 96

Audubon, John James, his birth and early years, 65 ; ornithological pursuits, 66 ; sails for Liverpool, 66 ; in Edinburgh, 66 ; his appearance, 66 ; drawings, 67 ; publication of his American 215
Birds, 67; procures additional specimens, 68, 72 ; preparations for a new work, Ornithological Biographies, 68 ; requires help in scientific descriptions, 69 ; meeting with MacGillivray, 69 ; characteristics, 69; knowledge of ornithology, 70 ; style of writing, 71 ; his appreciation of the work of MacGillivray, 72 ; excursion to the Highlands, 73 ; description of the scenery, 73 ; regret at leaving Edinburgh, 74 ; his love of Nature, 168, 178

Audubon, Marion R., 68

Audubon, Mrs, 71

Australia, scientific explorations in, 111

Awe, Loch, 35

Ayr, 36

Ballater, Pass of, 203, 206

Barclay, Charles, 6

Barclay, Dr George, physician to the Aberdeen Infirmary, 6 ; his pupil MacGillivray, 6 ; influence of his teaching, 26, 105, 116 ; his death, 57; tribute from MacGillivray, 58

Barclay, Mr George, 59

Barclay, Mrs, 58 ; her first impressions of MacGillivray, 59

Barnbogle ruins, 171

Barra, Island of, 112

Bass, the, 160

Bat, the long-eared, movements of, 128

Beallach-bhui forest, wind in the, 202 ; hills, 206

Beaton, Mrs, institutes the Mac- 
Gillivray Prize for Natural History, 155

Beattie, Dr, the "Bard of the North," 58

Ben Aun, 206, 207

Ben Lawers, 33

Ben Ledi, 167

Ben Lomond, 161, 167

Ben Macdhui, 28, 32

Ben Nevis, ascent of, 33

Benabuird, scenery of, 199

Berry, Walter, 57

Berwick Law, cone of, 163

Bho-dhoun, 206

Biology, interpretation of the history of, 123 note

Birch trees, aged, 200

Bird scene, a winter, at the mouth of the Almond, 170

Birds, classification, viii, 63 ; based on anatomy, 132-36: study of their habits, 123; flight, 167; merry-making, 203-5

Birds, American, publication of, 67

Birds, History of British, viii ; extracts from, 8-12, 121, 142, 166-95, 211-14; publication of the first three volumes, 74, 86, 115 ; scientific aspect, 87 ; features of the work, 91 ; illustrations, 95 ; publication of the fourth and fifth volumes, 109

Black, Adam, publishes the first volume of the Ornithological Biographies, 72

Blackbird, song of the, 178-80, 191

Blackie, Professor, student under MacGillivray, 98, 152

Blackwood, Captain, in command of the Fly, 111

Blair Atholl, 8, 29

Borrodale, scenery of, 43

Borve, 172

Botany, study of, 7, 23

Botany, Manual of, 86, 90, 115; extract from, 147

Braemar, 12, 28, 200, 206

Braid Burn, 92

Bristol Museum, 79

British Museum, visit to the, 53 ; criticism on the collection of birds, 81

Brixham, 211

Brown, J. A. Harvie, $x$

Brown, Mr, 78
Buffon, 147

Buonaparte, Lucien, 66

Burns, Robert. associations of, 36 ; his grave, 37

Buxton, 47

CAIRN Hill, 165

Callander, 73

Caltha palustris, 32

Calton Cemetery, monument to MacGillivray, 2, 109

Carex rigida, 199

Carlisle, 40

Cart shed, a night in a, 41

Castle Douglas, 37

Castleton, 12

Chaffinches, flight, 167 ; amusements, 203

Chambers, Robert, Vestiges of the Natural History of Creation, 147,151

Charleton of Aboyne, 28

Chatham Museum, 79

Chorley, 46

Clisheim, ascent of, 172-74

Clyde, the, 35, 73

Coal-tits, movements of, 204

Cormorants, 212

Corunna, Battle of, 1, 6

Coues, Dr, extract from his Key to North American Birds, 71

Cove, the rocks of the, 13

Cowie, Mr, 52

Craig Clunie, 202

Craigie, William, 13, 26, 116, 178

Crathes, woods of, 209

Crossbills, their mode of feeding, 174 ; colours, 175

Cruickshank, Dr Alexander, 153

Cruickshank, Miss, 153

Cuckoo, song of the, 191

Curlew, the, 176, 186, 192

Cuvierian and Linnæan levels, transition between, 123

Cyclopoedia of Anatomy and Physiology, 132

DANSKIN, Loch, 164

Darwin, Charles, Origin of Species, 88; his epithet for MacGillivray, 129 ; influenced by him, 155

Darwin, Erasmus, 147

De Luc, his treatise of Geology, 20, 21 
Dee, the $8,12,13,29,197,202,206$, 209

Deeside, Natural History of, 106, 118 ; style, 106, 118 ; preface, 107 ; extracts from, 92, 95, 108, 125-27, 144, 195-210

Denholm, his Tour to the Lakes, 38

Denholm, Captain, in command of the Herald, 111

Derby, 50

Derbyshire, 47

Dickie, Mrs, 66

Don, the 13,102

Dove, a tame rock, 169

Dublin College Museum, 79; criticism on, 81

Dublin Zoological Gardens, collection, 81

Dubrach, 12

Ducks, sports of, 205

Dumfries, 37

Dunbarton, 35 ; the Rock of, 35

Duncan, Dr Matthews, 103 ; on the influence of MacGillivray's teaching, 151 ; his first lessons in science, 152

Dunlins, 188-191 ; mode of searching for food, 189 ; their notes, 190 ; impressions made by their bills, 191

Dunstable, 52

EAGLES, sports of, 205

Edinburgh, 66 ; Calton Cemetery, 2, 109; College of Surgeons Museum, removal and arrangement of the collection, 75-77; Curators' reports on the work of MacGillivray, 78, 83 ; order and cleanliness, 82, 84 ; completion of the Catalogue, 83

Edinburgh Journal of Natural History and Physical Science, 86, $115,134,148$

Elgin, 174

Elliot, D. G., 71

Encyclopcedia Britannica, article on Ornithology in the, 86

Eoligary farm, 112

Esk, mouth of the, 188

FarquHarson, Rev. Dr James, 108,152

Fife, coast of, 160
Fly, the, expedition, 111

Fordoun, 58

Fort William, 33

Fraser, Alexander, 96

Fraser, Mr, 96

Fungus, description of a, 144

GaIRDNER, Dr, his motion of thanks to MacGillivray, 77

Galloway, Dr Rudolf, 156 note

Gannet, a, 212

Garlton Hills, 163

Geaully river, 29

Geddes, Lady, her appreciative record of MacGillivray, 102-5

Geddes, Prof. Patrick, on NatureStudy, 120; "Synthetic Outline of the History of Biology, 123 note

Geology, Manual of, 86, 115

German Ocean, 160

Gifford Woods, 160

Girvan, 37

Glasgow, 35, 73 ; College Museum, 78,79 ; criticism on, 80

Glaux maritima, 188

Glen Ballater mountains, 206

Glen Ey, 206

Glen Gairn, 207

Glen Tilt, 8

Glencoe, 33,35

Glenlivet, 174

Goethe, 147

Gor-cock or Lagopus scoticus, 208

Gordon, Mr, 112

Graftonregis, 51

Grampians, 10, 55

Gretna or Gretney, 38

Gull, the great black-backed, 194 ; flight, 168, 212 ; breeding-places, 195

HADDINGTON, 163

Hamilton, 73

Harris, island of, 1, 4, 7, 173; social life at, 18

Harris Mountains, 157

Havell, Mr, 67

Hawk, pursuit of a lark, 125-27

Hebrides, 4, 8; beauty of the scenery, 5; charm of the wild shores, 157

Hebrides, A Year's Residence and Travels in the 2, 24

Hecla, 157 
Hen-harriers, 182-84; their flight, 183 ; mode of hunting prey, 183 Herald Expedition, 111

Herminier, L', on the scientific system of birds, 134

Heron, the grey, 194

Highgate, 52

Hiliaire, St, Etienne Geoffroy, 147

Horsley, 45

Huie, Dr, his tribute to the services of MacGillivray, 85

Humboldt, Alexander von, condensation of his travels, $86,115,118$

Huxley, Prof., 128 ; on the staff of the Rattlesnake, 111

Inveraray, 34

Invercauld Bridge, view from, 197 Inverness, 173

Inversnaid, 73

JAMTESon, Prof., his lectures, 57, 60 Jamieson, Dr Thomas, his geological studies, 152

Katrine, Loch, 73

Keen, Mount, 206

Keith, Thomas, 103; his first lessons in science, 152

Kemnay, 14

Kendal, 44

Keswick, 40, 42

Kilda Isles, St, 157, 158

Kincardineshire, 58

Kindibig, Bay of, 172

King's College, Aberdeen, 6

Kingussie, 32

Kirk Alloway, 36

Knox, Dr, 63

IABRADOR, 169

Laggan, Loch, 33

Lagopuis scoticus, or gor-cock, 208

Lamarch, 147

Lammer-Law hill, 159

Lancaster, 45

Langdale, 43 ; glen, 174

Lapwing, the, 176

Largo Law, eminence of, 161

Lark, song of the, 128,181 ; pursued by a hawk, 125-27

Laurencekirk, 58

Leicester, 50

Leven, Loch, 35

Lewis, 173,174
Linn, the, 29

Linnæan and Cuvierian levels, transition between, 123

Liverpool, 66; Ḿluseum, 79; criticism on, 80

Lizars, Mr, publishes the American Birds, 67

Lochfyne, 35

Lochlomond, 35

Lochnagar, 196, 197, 202, 206, 207

Lochnaneun, crags of, 202

Loewis, von, investigations on stoats, 131

Loire, the river, 65

London, walk from Aberdeen to, 26-52

London University, anatomical and pathological collection, criticism on, 81

Long Island, 173

Lothian, East, 160

Loughborough, 48

Louisiana, swamps of, 168

Lubnaig, Loch, 73

Luskentir, 172

MacGillivray, Dr Donald Wm. takes his medical degree, 112; accepts the tenancy of the farm of Eoligary, Barra, 112 ; death, 113 ; interest in the ornithology of the Hebrides, 113

MacGillivray, John, 96 ; his scientific exploring expeditions, 111 explorations in Australia and the Pacific Islands, 111 ; death, 111 ; his study of the habits of the Aborigines, 111

MacGillivray, Dr Paul, 2, 106, 111; his devotion to natural science, 112 ; settles in Australia, 112 ; death, 112; monument to his memory, 112

MacGillivray, William, his birth, 1 ; at the island of Harris, vii, 1, 4, 18; death of his father, 1,6 ; his journals, 2 ; education, 4 ; study of Nature, vii, 5 ; at King's College, Aberdeen; 6; study of medicine, 6 ; mode of spending his holidays, 7 ; fascination for the study of botany, 7 , 25 ; his night journey from Blair Atholl to the Dee, 8-12; study of zoology, 13, 25; tour through 
part of the Highlands and Isles, 14 ; contents of his baggage, 14 ; objects of study, 15; spends a night near Loch Maree, 16; at Pollewe, 17; on the beneficial effects of travelling, 17 ; attachment to Marion $\mathrm{M}^{6}$ Caskill, 18 ; "survey" of his acquirements, 20-24; A Year's Residence and Travels in the Hebrides, 24; abandons the study of medicine, 26,57 ; dissector to the Lecturer on Anatomy at Marischal College, 26; his walk from Aberdeen to London, vii, 26-52 ; at Charleton, 28 ; at the base of Ben Macdhui, 28 ; his sense of reverential enjoyment, 32 ; at Kingussie, 32 ; Aberarder, 33 ; ascends Ben Nevis, 33 ; at Dunbarton, 35 ; Glasgow, 35; Ayr, 36; in the "Land of Burns," 36 ; at Girvan, 37 ; Dumfries, 37 ; discovers the grave of Burns, 37 ; at Springfield, 38 ; amount expended on the journey, 38,51 ; number of miles, 39,53 ; crosses the border, 40 ; trouble in changing a banknote, 40-42; spends a night in a cart shed, 41 ; at Keswick, 42 ; his impressions of Borrodale, 43 ; at Kendal, 44 ; on keeping the Sabbath, 44 ; at Lancaster, 45 ; Horsley, 45 ; impressions of Manchester, 46, 47 ; at Buxton, 47; Loughborough, 48 ; Ashbourne, 49 ; Graftonregis, 51 ; reaches London, 52; at the British Museum, 53; study of ornithology, 54, 87 ; his characteristics, 55, 64, 69, 90, 101, $104,107,110$; loss of his journals by fire, 56 ; return to Aberdeen, 56, 109; at Edinburgh, vii, 57 ; attends Prof. Jamieson's lectures, 57; death of his friend Dr Barclay, 57; poem and sketch of his life, 58 ; assistant and secretary to Prof. Jamieson, 60; marriage, vii, 61 ; resigns his appointment, 61,70 ; literary works, $61,86,115$; Conservator of the Surgeons' Museum, vii, 62 ; his book on the Rapacious Birds, 63, 75, 86, 115 ; assists
Audubon with the Ornithological Biographies, 65, 69, 115 ; meeting with him, 69; knowledge of ornithology, 70 ; style of writing, 71, 141-43; Audubon's appreciation of his work, 72 ; accompanies him to the Highlands, 73 ; publication of the first three volumes of his History of British Birds, viii, 74, 86, 115; work of removing and arranging the museum, 75-77 ; discharge of his duties, $75,77,82$; number of articles labelled, 76 ; tribute to his services, 77,85 ; inspection of museums, 79 ; criticisms on their condition, 80-2; his lectures on natural history, 83,86 ; completion of the catalogue, 83 ; resigns the conservatorship, 84 ; appointed Professor of "Civil and Natural History" in Marischal College, Aberdeen, viii, 84, $97,115,116$; views on Origin of Species, 88-91, 146-48 ; religious views, 89, 104, 107; Manual of Botany, 90, 115; meaning of his name, 91; descriptions of scenery, 91 ; Natural History of Deeside, 92, 118, 144; his sympathy with ravens, 93 ; deep sense of the mystery of Nature, $94,107,143,156$; his illustrations and water-colour drawings of birds, 95 ; mode of instructing his students, 98 ; magnetic influence, 98, 151; History of the Mollusca of the North-East of Scotland, 99, 137, 140, 152; preface to the book, 99 ; collection of zoological specimens, 100 ; considerate treatment of his students, 100-2, 105 ; appearance, 103; excursion to the upper part of the valley of the Dee, 106 ; illness, 108; relinquishes his class duties, 108 ; at Torquay, 109, 211 ; death of his wife, 109 ; publication of the fourth and tifth volumes of History of British Birds, 109 ; death, 109 ; number of his children, 110; sons, 111 ; an appreciation of his scientific work, 114 ; friends, 116 , 178 ; the all-round naturalist, 
117; the open-air naturalist, 119 ; on the value of field work, 121 ; the observer of habits, 123 ; his description of the pursuit of a lark by a hawk, 125-27; delight in details, 128; accuracy, 129, 137 ; independence of thought, 130,137 ; character as an ornithologist, 131 ; views on classification based on anatomy, 132-36; the alimentary system, 132; his Celtic temperament, 139 ; enthusiasm for Nature, 139 ; on the wealth of life, 143; description of a fungus, 144 ; of a squirrel, 145 ; of the nest of a long-tailed tit, 146 ; on variations in Nature, 148-50; influence as a teacher, 150-55; originator of a Natural History Society in Aberdeen, 155; ascent of a mountain, 166 ; on Clisheim in a snowstorm, 172-74.

MacGillivray, William, his sketch of MacGillivray's life and work, 2

MacGillivray, William Lachlan, 155 ; his ornithological collection, 113

MacGillivray, Mrs, her death, 109

Machar, St, Cathedral of, 102

MacHardy, 12

MacLagan, Dr, 85

Macleod, Rev. Mr Alexander, 172

Manchester, 46 ; impressions of, 47

Maree, Loch, 16

Marig, 172

Marischal College, Aberdeen, Professorship of Natural History in, 97, 115, 116

Maritime Pastures of the Western and Eastern Coasts of Scotland, On the, extract from, 156-58

Maryculter, 210

May, Isle of, 160

M'Caskill, ḾTarion, 18, her marriage, 61 , see MacGillivray, Mrs

M'Caskill, Mary, 18

Medicine, study of, 6

Merle or mavis, song of the, 181

Merlin, the, 64; description of, 159; catching a snipe, 161 ; flight, 165

Miller, Hugh, his views on creation, 90
Milton Burn, 161

Missouri, trackless woods of, 168

Mollusca of the North-East of Scotland, History of the, 99, 137 ; preface, 99, 140, 153 ; result, 152

Mona-Chuine, 207

Montague, his collection of birds in the British Museum, 81

Moor, the Highland, scene on a, 205

Mountain, thoughts inspired by the ascent of a, 166

Muic, Loch, 206

Müller, Johannes, 135

Murchison, Charles, his first lessons in science, 152

Murray, John, x

Musselburgh, 188

Mustela erminea, or the stoat, 130

Nature, variations of, 148-50; the mystical solace of, 156 ; object of the study, 198

Neill, Dr, of Canonmills Lodge, 96

Newton, Prof. Alfred, 132; on MacGillivray's system of classification of birds, 135-37

Normanby, Marquis of, 84

Northampton, 51

Northtown farm, 1, 4, 6

OвBE, parish school at, 4

Ochil Hills, 161

Ecology or Bionomics, the study of, 123

Ornithological Biographies, preparations for writing, 68 ; commencement of the joint work, 71,115 ; number of volumes, 72 ; completion, 73

Ornithology, study of, 23, 54; article on, 86 ; system of classification, 88, 131 ; the alimentary system, 132

Ouzel, the ring, 177

Owen, Sir Richard, his article "Aves," 132

Pacific Islands, scientific explorations in, 111

Paisley, 36

Park Mountain, 174

Peebles, 159 
Pentlands, the, 119

Pine trees, size of, 202 ; three, 208

Pirie, Prof., attends MacGillivray's lectures, 152

Playfair, Mr, 75

Plover, the golden, 162, 176, 18486 ; their nests, 177 ; song, 184 ; pages, 186 ; ring, 186

Pollewe, 16, 17

Portland Island, 212

Pyecraft, W. P., x

Quadrupeds, History of British, 86,115

Rapacious Birds of Great Britain, Descriptions of the, 86, 115; extracts from the preface, 13 , $25,57,60,62,63,87$; dedication, 75

Rattlesnake Expedition, 111

Ravelston Woods, 96

Ravens, $93,175,177$; sports of, 205

Ring-Plover, the Common, 186

Rooks, flight of, 167

Ross, 173

SABBatH, mode of keeping the, 44 Salix herbacea, 31

Sandpipers, 177, 190 ; flight of, 171

Schiehallion, 33

Schwalbe, Prof., his investigations on stoats, 130

Scott, Sir Walter, his impression of Audubon, 67

Seaforth, Loch, 172

Sea-pie, the, 187

Shand, Mr James, accompanies MacGillivray on a tour, 14; spends a night near Loch Maree, 16

Silene acaulis, 31

Sim, George, The Vertebrate Fauna of Dee, 155

Skye, 21, 24, 173

Smith, Sir Charles, Flora Britannica, 14, 19, 26

Snipe, the song, 176 ; shrill twonoted cry, 192 ; drumming sound, 164, 192

Sparganium natans, 32

Sparrows, flight of, 167

Species, views on the origin of, 88 , 146-48; variations, 148-50
Spey, the, 32, 174

Springfield, 38

Squirrel, habits of, 128 ; description, 145

Stanley, Capt. Owen, in command. of the Rattlesnake, 111

Stirling, 73

Stoats, investigations on, 130

Stoney-Stratford, 51

Stranraer, 37

Stratford, 52

Strathspey, 28, 32

Sydney, 111

"TACKSMEN," meaning of the term, 18

Tarbert, Loch, 172

Thomas's Hospital, St, criticism on, 82

Thomson, Prof. J. Arthur, "MacGillivray's Scientific Work-an Appreciation." ix, 114

Thrush, song of the, 180

Tit, the long-tailed, number of feathers in the nest, 128,146 ; description of the nest, 146

Torquay, 109 ; scene at, 211

Torres Straits, 111

Totanus hypoleucos, or sandpiper, 190

Trail, Prof. J. W. H., 147; "Natural Science in the Aberdeen Universities," 116 note, 154 ; on the characteristics of MacGillivray, 120, 129; on the value of his book The Mollusca of Scotland, 153

Traprain eminence, 163

Travelling, benefits from, 17

Treviranus, 147

Trossachs, the, 73

Tulloch, Loch, the ravens at, 93

Turner, H. N., 137 note

Tweed, the, 194

Tyrannus verticalis, or Fly catcher, 136

Uig Mountain, 174

Uist, South, island of, 1, 112, 157, 173

Urga, 172

Vaccinium myrtillus, 203

Vestiges of the Natural History of Creation, 147, 151 
Victoria, Queen, the History of British Birds, dedicated to, 86 ; acquires the manuscript of The Natural History of Deeside and Braemar, 106

WATER-RAT, the, 194

Water-shrew, movements of, 128

Weir, Mr, 178

White, Dr John F., on the influence of MacGillivray's teaching, 15153

Wilson, Mr James, 69

Wilson, Mr, janitor of the Edinburgh University, 60
Windermere, 44

Wisely, Rev. Dr, 103

Withering, Arrangement of British Plants, abridgment, 115

Wood, Mr, his tribute to MacGillivray, 77

Woodpecker, number of insects in the stomach of $a, 129$

Wood pigeons, flight of, 167

Zimmerman on Solitude, 12

Zoologists, Lives of Eminent, 115, 140 ; extracts from, 143, 144

Zoology, Manual of, 86 ; study of, 13,23

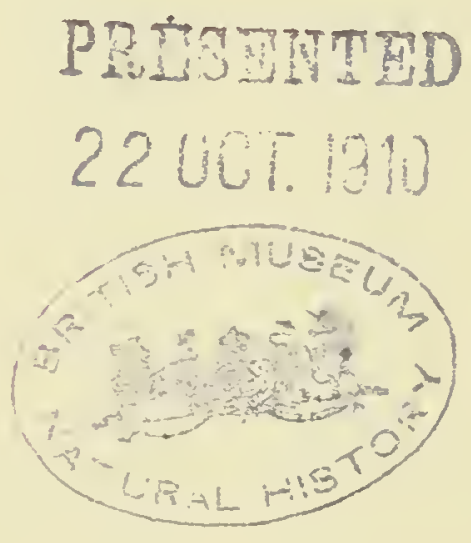

PRINTED BY OLIVER AND BOYD, EDINBURGH 
A TREATISE UPON THE LAW OF COPYRIGH'T: in the United Kingdom and the Dominions of the Crown, and in the United States of America. Containing a full Appendix of all Acts of Parliament, International Conventions, Orders in Council, Treasury Minutes, and Acts of Congress now in force. By E. J. MacGillivray, LL.B Cantab., of the Inner Temple, Barrister-at-law; Member of the Faculty of Advocates in Scotland. Medium 8vo. 25s. net.

" Mr MacGillivray has certainly produced an eminently useful work on a subject that is all-important to authors and publishers. . . . Moreover it is 'the author' in the largest sense, not only the author of books, to whom this work appeals . . . very complete and accurate . . admirable text-book."-Spectator.

THE LIFE OF PHILIBERT COMMERSON, D.M., Naturaliste du Roi. An Old-World Story of French Travel and Science in the days of Linnæus. By the late Captain S. Pasfield Oliver, R.A. Edited by G. F. ScorT Eulior, F.L.S., F.R.G.S. With Illustrations. Demy 8 vo. 10 s. 6 d. net.

"A most fascinating work . . . so full of romance and poetry that it is difficult to believe one is reading the work of a serious naturalist, who underwent every kind of hardship, enduring the utmost privations, and frequently risking his life in pursuit of the science he loved so well. . . The story of this gallant and ill-used martyr of science should stimulate and encourage every real naturalist who reads about him, for his liberal and reverent spirit is intensely refreshing in this materialistic age."-Morning Post.

RECEN'T ADVANCES IN THE STUDY OF VARIA'TION, HEREDI'TY AND EVOLU'TION. By Robert H. Lock, M.A., Fellow of Gonville and Caius College, Cambridge. With Portraits and other Illustrations. Crown 8vo. 5s. net.

MICROSCOPY. The Construction, Theory, and Use of the Microscope. By Edmund J. SpitTa, F.R.A.S., F.R.M.S., etc. With numerous Diagrams and Illustrations. Second Edition. 12s. 6d. net.

"Let us hasten to urge every student of the microscope who wishes to gain a thorough understanding of its principles and possibilities and its defects, and every user of the instrument who desires a work of reference to which he may turn for an explanation of some unexplained optical phenomenon, or for particulars of up-to-date apparatus, to procure a copy of $\mathrm{Mr}$ Spitta's book without delay."-Nature. 


\section{THE RECENT DEVELOPMENT OF PHYSICAL}

SCIENCE. By W. C. D. Whetham, M.A., F.R.S. Illustrated. Large Crown 8vo. 5s. net.

Introduction-The Philosophical Basis of Physical ScienceThe Liquefaction of Gases and the Absolute Zero of Temperature - Fusion and Solidification-The Problems of Solution-The Conduction of Electricity throvgh Gases-Radio-Activity-Atoms ANd Ether-Astro-Physics-Index.

HEREDITY. By J. Arthur Thomson, Regius Professor of Natural History in the University of Aberdeen; Author of "The Study of Animal Life." With Coloured and other Illustrations. Large Crown 8vo. 9s. net.

"The results of his labours are now presented to the world in a volume which may be regarded as the standard work of reference on this subject. To the biologist it will prove indispensable ; while to the student of sociology, and to the medical man, it will probably come as a revelation. . . . As a judicial summary of an exceedingly difficult and controversial subject it is masterly, while in the matter of clearness of exposition it has no rival.

- . In marshalling his facts he has displayed an amazing skill, for he has placed the most abstruse facts in a light so strong and clear that any possible shadows of misconception are effectually dispelled. $\mathrm{He}$ has swept within his net all that has been said on this most difficult theme, and thereby has laid us all under a debt of gratitude. And the truth of this estimate will soon be obvious to those who read this book." -Knowledge.

"The whole book is fascinating and instructive, and we cordially commend it to all who are interested in the subject with which it deals. . . . It is very complete, lucidly written, and adequately illustrated."-The Lancet.

"Any one who wishes seriously to pursue the study of the modern facts and theories cannot, whatever his linguistic acquirements, do better than read Professor Arthur Thomson's Heredity." -British Medical Journal.

\section{SCIENCE PROGRESS IN THE TWENTIETH CENTURY.} A Quarterly Journal of Scientific Work and Thought. Edited by H. E. Armstrong, Ph.D., LI.D., F.R.S.; J. Bretland Farmer, M.A., D.Sc., F.R.S.; and W. G. Freeman, B.Sc., F.L.S. About 192 pp. Illustrated. 5s. net. Subscription $£ 1$ per annum, post free throughout the World.

Advisory ComimitT'ts : Horace T. Brown, LL.D., F.R.S. ; R. Glazebrook, M.A., Sc.D., F.R.S.; H. J. MAckinder, M.A.; J. E. Marr, M.A., Sc.D., F.R.S.; H. A. Miers, M.D., D.Sc., F.R.S.; E. A. Minchin, M.A.; P. Chalmers Mimcheli, M.A., F.R.S.; Sir W. Ramsay, K.C.B., Ph.D., Sc.D., F.R.S.; SIR A. Rucker, M.A., D.Sc., F.R.S.; E. H. Starling, M.D., F.R.C.P., F.R.S.; A. D. WALlER, M.D., LL.D., F.R.S.

"Science Progress" contains original papers and summaries of the present state of knowledge IN ALL BRANCHES OF SCIENCE of an authoritative character, written by those actually engaged in advancing knowledge on the subjects with which they deal. That very tangible success has been attained in realising these ideals is demonstrated by the papers which have appeared in the seven numbers already issued.

Write for Specimen Copy, Post Free. 





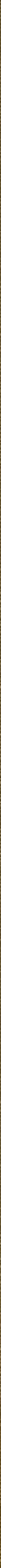

